THE RENEGOTIATION OF

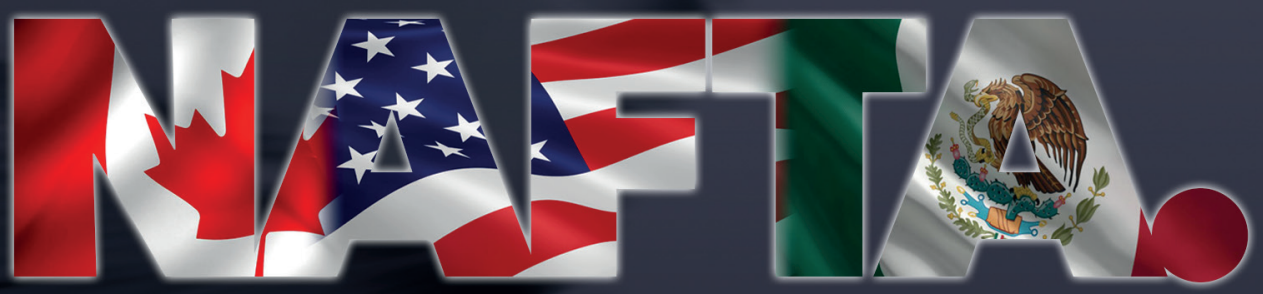

\title{
AND
}
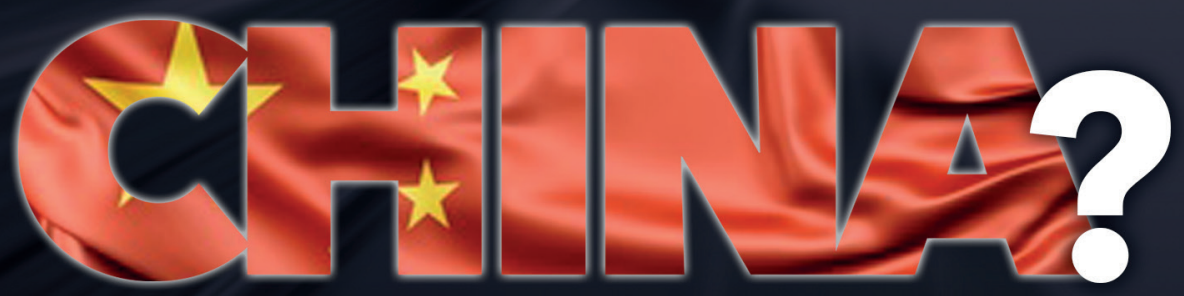

Edited by

Enrique Dussel Peters 



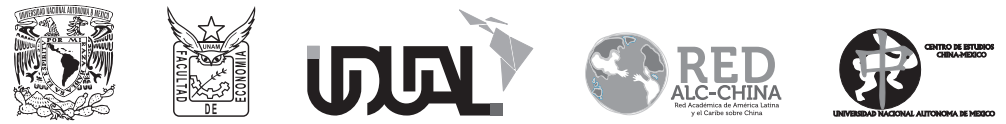

\section{THE RENEGOTIATION OF}

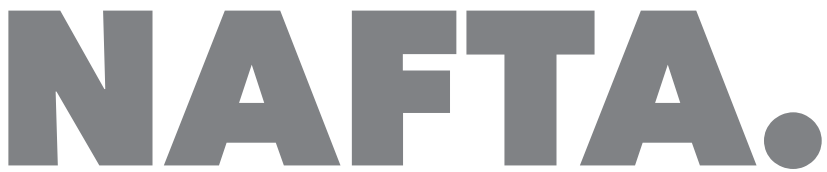

AND

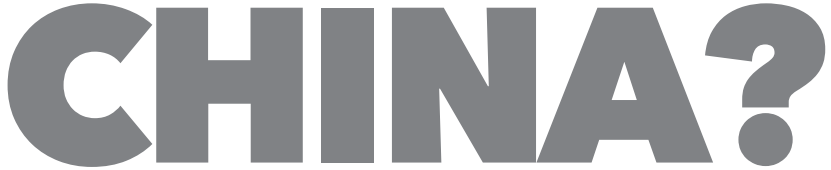

Edited by

Enrique Dussel Peters 


\section{UNIVERSIDAD NACIONAL AUTÓNOMA DE MEXICO}

$\begin{array}{ll}\text { Enrique Luis Graue Wiechers } & \text { Rector } \\ \text { Leonardo Lomelí Vanegas } & \text { Secretario General } \\ \text { Leopoldo Silva Gutiérrez } & \text { Secretario Administrativo } \\ \text { Alberto Ken Oyama Nakagawa } & \text { Secretario de Desarrollo Institucional } \\ \text { Raúl Arcenio Aguilar Tamayo } & \text { Encargado del despacho de la Secretaría de Atención } \\ & \text { a la Comunidad Universitaria } \\ \text { Mónica González Contró } & \text { Abogada General }\end{array}$

\section{UNIÓN DE UNIVERSIDADES DE AMÉRICA LATINA Y EL CARIBE}

Henning Jensen

Roberto Escalante Semerena

http://wwwudual.org

\section{FACULTAD DE ECONOMÍA}

Eduardo Vega López

Director

Alberto Morales Sánchez

María del Carmen Aguilar Mendoza

Secretario General

Juan M. M. Puiz Llano

Secretaria Administrativa

Coordinador de Publicaciones

\section{RED ACADÉMICA DE AMÉRICA LATINA Y EL CARIBE SOBRE CHINA}

Enrique Dussel Peters

José Ignacio Martínez Cortés

Yolanda Trápaga Delfín

Liljana Arsovska

http://www.redalc-china.org/v21/es-es/
Coordinador General y Coordinador del eje temático Economía, comercio e inversión

Coordinador del eje temático Relaciones politicas e internacionales

Coordinadora del eje temático Recursos naturales y medio ambiente

Coordinadora el eje temático Historia, cultura y aprendizaje del chino

\section{CENTRO DE ESTUDIOS CHINA-MÉXICO}

Enrique Dussel Peters

Yolanda Trápaga Delfín

http://www.economia.unam.mx/cechimex
Coordinador

Responsable

The Renegotiation of Nafta. And China?

Enrique Dussel Peters

Coordinador

Edición

Amanda Morgan

Diseño y formación de interiores

D.R. (C2018, Universidad Nacional Autónoma de México,

Facultad de Economía

Ciudad Universitaria, 04510, México, D.F.

Primera edición: diciembre de 2018

ISBN: 978-607-8066-43-8

"Prohibida la reproducción total o parcial por cualquier medio sin la autorización escrita del titular de los derechos patrimoniales"

Impreso y hecho en México/Printed and made in Mexico. 
THE RENEGOTIATION OF

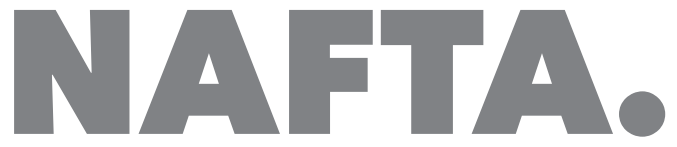

AND

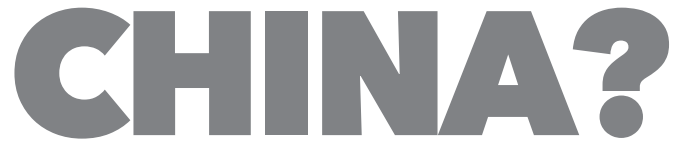

Edited by

Enrique Dussel Peters 



\section{Contents}

Preface

Enrique Dussel Peters

Section I. NAFTA and Its Renegotiation

Globalization, Regional Integration, and Renegotiation of NAFTA 13 Hongxia Wei

Renegotiating NAFTA: The Paradox of economic integration and political disintegration

Cuiwen Wang

How China, Mexico and U.s. Relations Explain the $21^{\text {st }}$ Century: Transnational Policy Linkages of Trade, Migration and Remittances

Raúl Hinojosa-Ojeda

Modernizing NA FTA : Transformation, Negotiation, and Unequal Results

Clemente Ruiz Durán 
Possibilities for the Expansion of Intra-industry

Trade Between China and Mexico

Jorge Eduardo Mendoza Cota

Mexico's Trade Relations with nAf TA Partners and

with China from the Perspective of the Mexican Footwear Industry Alejandro Gómez Tamez

\section{Section II. And China?}

The New Triangular Relationship Between Mexico, the United States, and China: Challenges for NAFTA Enrique Dussel Peters

The Role of Trade with China in Mexico's Renegotiation of NAFTA

Simón Levy-Dabbah

The New Digital Relationship between Mexico and China José Ignacio Martínez Cortés and María del Carmen González Velásquez 


\title{
Preface
}

\author{
Enrique Dussel Peters
}

After a little more than a year, the three members of the North American Free Trade Agreement (NAFTA) finished negotiations at the end of September 2018, for what is now called the United States-Mexico-Canada Agreement (US MCA). The agreement is still awaiting the approval of the three countries' legislatures, which will probably take place in the first quarter of 2019. Changes, particularly from the us perspective, can still occur, and considering new majorities in the House of Representatives.

A detailed analysis of the final version of U SM CA, particularly in contrast with NAFTA, will have to take place in 2019 once the final version of the agreement is accepted in all three countries. So far, however, several points can be noted. In general, differences between USMCA and NAFTA are minor, considering the threats by and initial stance of the Trump administration in 2017. U s M C A, for example, increases the percentage required under the rules of origin for automobiles from 62.5 percent to 75 percent, in addition to quantity restrictions on U imports and requirements for Mexican wages; similar quantitative barriers for Canadian dairy exports were agreed on. However, probably the most relevant change in USMCA is its general protectionist and defensive posture: while the original NAF TA explicitly held open the possibility of new members, such as Chile, Us MCA in Article 32.10 explicitly excludes 
the possibility of any of its members negotiating free-trade agreements with "non-market economies" such as the People's Republic of China. The NAFTA region, from this perspective, could become the first international "anti-China" region.

With these circumstances in mind, the goals of this book include analysis of the main results of NAFTA since January 1994 and the increasing relevance of China for the NAFTA region and each of its members. From this perspective, NA FT A, and now U S MC A, should explicitly analyze and evaluate the implications of China's rising presence in the region in several economic sectors and, based on this analysis, offer explicit policy responses to it. This, so far, has not happened either in NAFTA or in USMCA.

The book is divided in two sections and presents nine articles by 10 authors; each author was asked to present a concise analysis of a specific issue and offer related policy suggestions.

The first section's six chapters discuss particularities of NAFTA's integration process, as well as the process of renegotiating NAFTA and the impacts of China on these events and trends. Hongxia Wei compares us President Trump's America First approach and China's One Belt, One Road initiative and their impacts on globalization, NAFTA, and Mexico; Cuiwen Wang compares the increasing economic integration of the NAFTA region with its increasing political and social divisions. The four chapters that follow focus on more specific elements of NAFTA's implementation. Raúl Hinojosa-Ojeda predicts that global shifts in production, trade, and urbanization will continue to increase global immigration to the United States, but that immigration will come less from Mexico and more from China. Clemente Ruiz Durán points out that the NAFTA region as a whole has substantially increased imports, particularly from China and in global commodity chains such as auto parts and automobiles; the analysis by Jorge Eduardo Mendoza Cota notes the substantial difference between Mexico's high level ofintraindustry trade with the United States and its significantly lower level of the same type of trade with China, and the potential for expansion of these trade relationships. Trends in the global footwear value chain, 
discussed by Alejandro Gómez Tamez, have been somewhat counterintuitive and have not lived up to initial expectations for the NAFTA integration process: intra-regional trade has fallen substantially in the face of competition from Asia, particularly from China and Vietnam.

The second section of the book focuses explicitly on a group of topics of NAFTA related to China and presents three additional analyses and their respective policy proposals. Enrique Dussel Peters accounts for China's increasing trade presence in the NAFTA region, NAFTA's disintegration since China's accession to the World Trade Organization in 2001, and China's medium- and high-tech exports to the region, while Simón Levy-Dabbah calculates the increasing role of Chinese imports to Mexico as inputs in Mexican manufactures that are exported, mainly to the United States, with substantial limitations for Mexico's long-term development. Finally, José Ignacio Martínez Cortés and María del Carmen González Velásquez argue that Mexico and China have an important potential in terms of their new digital relationship, in services in general and particularly in service sectors such as telecommunications, information, communication, and knowledge.

Most of these issues - from trade in specific global value chains to immigration and the new digital arena- have not been explicitly or implicitly addressed in U SM CA and will require more detailed analysis and evaluation of NAFTA and USMCA. A full 24 years after the implementation of NAFTA, there has been no explicit public evaluation of that agreement, particularly in terms of global value chains, by region and by the main topics presented in NAFTA since 1994.

From that perspective, this book is an invitation to deepen reflections on NAFTA's successes, failures, and challenges, for the region and each of its members, particularly vis à vis China. As discussed in each chapter, China presents a number of issues for the NAFTA region, relating to trade, investment, and specific global value chains, as well as migration and other intra-NAFTA matters. This approach has so far not resolved them, and the aforementioned Article 32.10 of U S MCA (restricting future trade agreements with "non-market economies" such as China) will also clearly not resolve these urgent and widespread issues. 

Section I.

\section{NAFTA and Its Renegotiation}





\section{Globalization, Regional Integration, and Renegotiation of NAFTA}

Hongxia Wei

Since 2016, the world has experienced great changes. Existing international trends and patterns have both evolved and retreated. The United Kingdom's move toward Brexit marked the disintegration of the European Union (EU) and weakened confidence in regional multilateral cooperation worldwide, from A E E C (Asia Pacific Economic Cooperation) to NAFTA (North American Free Trade Agreement) and T P P (Trans-Pacific Partnership). The United States, under the Trump administration's "America first" approach, has triggered a major adjustment in international trade and led to a trend of deglobalization.

\section{Globalization: Going forward or pulling back?}

Globalization is primarily an economic process of integration that has social and cultural aspects, but conflicts and diplomacy are also large parts of the history of globalization. It represents the global integration of international trade, investment, information technology, and cultures. It is driven by government policies designed to open up economies domestically and internationally to boost development in poorer countries and raise standards of living (Investopedia n.d.). Globalization has affected nearly every aspect of modern life. While it has a few drawbacks, most economists agree that it is both unstoppable and net beneficial to 
the world economy (Kuepper 2018). Globalization benefits individual economies around the world by making markets more efficient, increasing competition, limiting military conflicts, and spreading wealth more equally around the world. It does this in the following ways:

1. Foreign direct investment tends to increase at a much greater rate, helping boost technology transfer, industrial restructuring, and the growth of global companies.

2. Increased competition helps stimulate new technology development, particularly with the growth in foreign direct investment, which helps improve economic output by making processes more efficient.

3. Globalization enables large companies to realize economies of scale that reduce costs and prices, which in turn supports further economic growth, although this can hurt many small businesses attempting to compete domestically.

As the world has become more closely connected than at any time in the past, globalization is promoting two prominent new trends: the rapid emergence of new technologies, especially in the field of communication, and the steady growth of emerging economies -such as Brazil, China, India, and Mexico - which are key drivers of world development.

However, some economists have identified a retreat in globalization since the us presidential election in 2016. Key examples include President Trump's withdrawal of the United States from the TP p, demand for renegotiation of NAFTA, and threat of a trade war with China and other countries, all under the Trump administration's "America first" policy with the avowed goal of "leveling the playing field" for American businesses.

The United States, which has led the globalization trend since World War II, seems to be marching to the tune of a new nationalism and protectionism. The Trump administration's actions have left the United States isolated on global trade, as the rest of the world has continued pursuing multilateral cooperation, notably through the Japan-EU and EU- 
Mercosur agreements. Countries other than the United States are providing new solutions and strategies for global governance. With the leadership of Japan, which is a close Us security ally, T P P is moving forward without the United States. China's government is making efforts to provide solutions, which was put forth as an idea of "a community of shared future for mankind” (人类命运共同体)and the Belt and Road Initiative. Chinese President Xi Jinping said, "facing the fast changing international and regional landscapes, we must see the whole picture, follow the trend of our times, and jointly build a regional order that is more favorable to the world." (Xinhuanet 2015)

Globalization is inevitable over the long run, but there are many bumps in the road in the short run. These are often created by economic crisis or the negative consequences of globalization, but in the end, the world has always learned that protectionism can make a bad situation worse. Most economists agree that there have been periods of protectionism and nationalism in the past - and that globalization has produced problems such as unequal development because of industrial transition, capital outflow, and wealth disparity- but globalization continues to be the most widely accepted way to ensure consistent economic growth around the world. If any country wants to drop out of the global trend toward integration, it will develop protectionism and extremism. Moreover, the more developed economies have more close relations with the outside world. Rejecting globalization is dangerous for one's own economy and even society.

\section{Regionalism: Abandoned or embraced?}

Commencing with European economic blocs such as the European Coal and Steel Community and the European Economic Community, established in the 1950s, waves of regional integration or regionalism have occurred simultaneously with globalization. The Eu has been seen as a model of regional integration. A wave of regional integration occurred in the late 1980s and early 1990s, when NAFTA was created as a 
model that integrated two developed countries and one developing country. In the mid-1990s, East Asian countries began organizing multilateral frameworks to facilitate economic growth and solve regional security and social problems. Among these, A PEC and TP P are transPacific agreements that embrace some western-hemisphere countries such as the United States and Mexico and aim to enhance cross-Pacific economic cooperation.

It has been argued that regional cooperation frameworks (e.g., security regimes and trading blocs) are a backlash against globalization, but their role as alternatives to global frameworks such as the World Trade Organization negotiation has never been ignored. A P EC has played a comprehensive role during its nearly 30 years, although it is frequently criticized for its ineffectiveness and its loose flexible way of leadership. The Us Obama administration made a vigorous effort to complete T P P negotiation. T P P provides strict high-level trade standards. It was a victory for President Obama's trade policy, which made China worry about its trade environment. President Trump withdrew the United States from the T P P as his top agenda priority after taking office. However, no other partners abandoned the TPP, and Japan assumed an active leadership role. Mexico did not quit the T P P, either. These countries are still grasping opportunities for economic growth through multilateral cooperation while developed countries like Britain and the United States are planning to abandon regional multilateral cooperation, seeking unilateralism, and risking protectionism.

The United States should be aware that regional trade bloc leadership roles will not remain vacant when it withdraws. Regional cooperation, with its relatively easy geographic access and greater commonalities in social culture, is likely to strengthen while globalization tentatively retreats. 


\section{Renegotiation of NAFTA: Will China be a factor?}

The election of Donald Trump as the president of the United States has brought panic to the existing world trade order, which was built by Us efforts in past decades. Renegotiating NAFTA was one of Trump's major campaign promises. Just a few weeks after assuming office, the Trump administration embarked on a bigger quest - resetting a global trade consensus that had persevered for over four decades. President Trump signed an executive order on January 23, 2017, to renegotiate NAFTA. He demanded that Mexico end its value-added tax on us products, which he claimed acts as a tariff on us exports to Mexico. Trump also asked Mexico to end the maquiladora program, arguing that it undercut American workers by sending jobs to Mexico. These were the first steps in rewriting global trade rules, a goal that the Trump administration vowed to pursue.

NAFTA entered into force on January 1, 1994. It was controversial when first proposed, mostly because it was the first free trade area involving two wealthy, developed countries (the United States and Canada) and one developing country (Mexico). When it was first proposed, the political debates surrounding it were divisive in the United States. Supporters argued that the agreement would help generate thousands of jobs and reduce income disparity in the region, while opponents warned that it would cause huge job losses in the United States as companies moved production to Mexico to lower costs. According to a report by the us Congressional Research Service, "In reality, NAFTA did not cause the huge job losses feared by the critics or the large economic gains predicted by supporters. The net overall effect of NAFTA on the U.S. economy appears to have been relatively modest" (Villareal and Fergusson 2017). Since 1993, the year before the agreement took effect, US trade with its NAFTA partners has more than tripled (see Figure 1), increasing more rapidly than trade with the rest of the world.

The Trump administration has obviously focused on the issue of job losses and exaggerated the negative effects of NA FTA. One of the biggest ironies in trade policy is that, despite Mr. Trump's opposition to the T P P, 
Figure 1. us trade with Canada and Mexico, 1993-2017

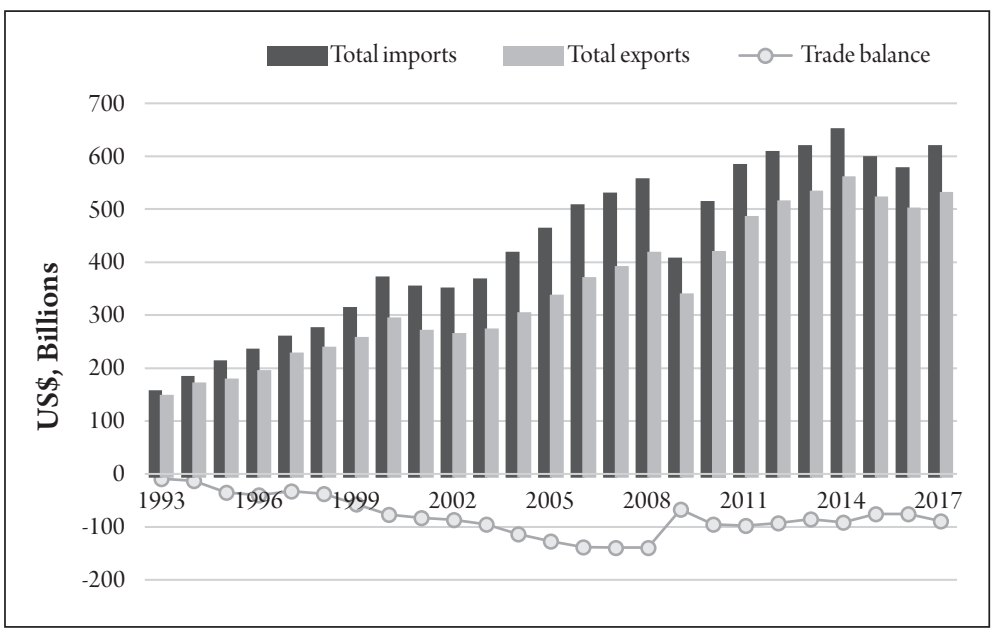

Data source: U SITC (n.d.).

key provisions for $\mathrm{T} P \mathrm{P}$ negotiation may also be addressed in renegotiating NAFTA. Many of the provisions mentioned in a plan for renegotiating NAFTA (USTR 2017) -including measures to regulate treatment of workers, the environment, and state-owned enterprises-appeared to be lifted upgraded from the T P P agreement. This suggests that what the Trump administration wants from trade negotiation is to dominate the agenda and the rules of the game.

NAFTA renegotiation is a key component of the Trump administration's trade policy. People all over the world are focusing on its progress and final outcomes. A successful renegotiation of NAFTA would be another milestone, demonstrating that such deals can be living agreements that can be updated and improved and continue to work in the interests of both wealthier and poorer countries. A failure, however, would worsen the erosion of public confidence in trade. This would not benefit the Trump administration's trade policy adjustment, which is the top agenda.

Some Us economists have warned that in NAFTA renegotiations, Mexico can now leverage China's growing foreign direct investment in 
the region. With China increasing and diversifying its Latin American investments, Mexico and other Latin American countries are rethinking their traditional trading relationships. Chinese President Xi Jinping has pledged to increase trade with Latin America by US\$500 billion and increase foreign investment by US $\$ 250$ billion by 2025 , yet China is still only Mexico's third largest trading partner. China-Mexico trade ties have grown significantly -up to US\$43 billion in 2017- but this is still much smaller than the US $\$ 580$ billion in trade between the United States and Mexico.

China, as a strong trading partner, will provide Mexico greater export diversity and significant trading growth opportunities in several ways. First, the trend toward integration under NAFTA has solidified Mexico's dependence on the us market and economic growth -its manufacturing systems, infrastructure investments, and even national economic priorities are all oriented toward its northern neighbor. Undoubtedly, whether renegotiating NAFTA or adjusting its domestic market, the Trump administration's policy is focused on us economic growth. This is likely to put Mexico and us other trade partners in peril of slowing

Figure 2. Volume of trade between China and Mexico, 1998-2016

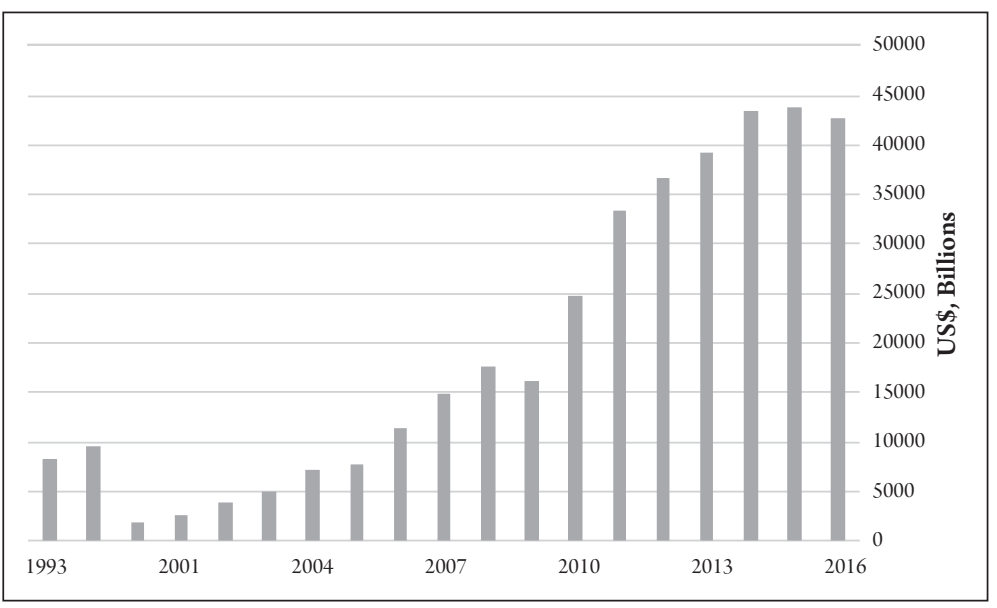

Data source: compiled according to trade data from National Bureau of Statistics of China, the data base is available at the official website: http://data.stats.gov.cn/easyquery.htm? $\mathrm{cn}=\mathrm{C} 01$. 
growth. Mexico and China, given their rapidly growing trade volume (see Figure 2), should seek ways to strengthen cooperation to improve their resilience to risk of economic recessions.

Second, Mexico should pay close attention to China's recent reforms and seek opportunities for economic cooperation. China is transforming and upgrading its economic structures. As trade partners, Mexico and China presented structural challenges to each other in the past, such as competition on textile exports. As the Trump administration reconsiders us trade partnerships, Mexico and China should restructure their trade cooperation and take advantage of mutual opportunities in their domestic markets and the international market. China's recent reforms could become Mexico's opportunity to leverage the Trump administration's challenge.

Third, an effort that has attracted substantial attention is the Maritime Silk Road Initiative, part of China's Belt and Road Initiative - a development strategy that focuses on connectivity and cooperation and has already reached out to Latin America countries. Under the initiative, the Silk Road Fund and the Asian Infrastructure Investment Bank, which pursue infrastructure-based development, would foster "economic connectivity and a new type of industrialization in the Asia Pacific region. Mexico, as a major power in that region, should closely follow these trends and take the advantage of them.

Fourth, in the past, the long distance across the Pacific Ocean has been the main barrier to trade growth between China and Mexico. Nowadays, better transportation and communications technology has reduced such obstacles and facilitated goods exchange all over the world. Both China and Mexico should seize the opportunity to expand trade cooperation.

China will never completely replace the United States as a Mexican trading partner, but the prospect of a bigger trading relationship with China could definitely give Mexico leverage and increased flexibility in NAFTA renegotiations. 


\section{Conclusions}

Globalization is likely to persist long-term and strengthen in the coming years. Cooperation among countries will not be interrupted or ended even if the Trump administration's protectionist trade policy has sparked tensions with China, its close neighbors, and other allies. In an era of globalization, countries and companies are connected through mutual benefits and responsibilities as well as through technology. History has seen periods of protectionism and nationalism before, and globalization has produced problems such as unequal development because of industrial transition, capital outflow, and wealth disparity. But globalization continues to be the most widely accepted way to ensure consistent economic growth around the world.

Regional cooperation is not an adversary of globalization, but a complement to it. The world still faces many security problems. Countries need to take responsibility for solving these problems through negotiation and compromise and with confidence.

Since he assumed office, President Trump has brought new peril and disorder to the world by creating difficulties in us trade with other countries. As a large developing country, Mexico has some advantages and should use them to counter setbacks brought by the Trump administration's protectionist policy.

\section{References}

Dayen, David. 2017. “Trump's Renegotiation of NAFTA Is Starting to Look a Lot Like the т P." The Nation, July 18.

Fan, Libo, and Yizhou Shi. 2017. "Respond to Deglobalization in an Objective and Sensible Way. [In Chinese.] 《光明日报》[Guangming Daily], April 2.

Investopedia. n.d. "Globalization". www.investopedia.com/terms/g/ globalization.asp. 
James, Harold. 2017. Deglobalization as a Global Challenge (Cig I Paper 135). Waterloo, on, Canada: Centre for International Governance Innovation.

Kuepper, Justin. 2018. "The Impact of Globalization On Economic Growth." The Balance, August 13.

National Bureau of Statistics of China. (n.d.). "Total Volume of Imports and Exports Countries(regions) in Latin America," available at: http://data.stats.gov.cn/easyquery.htm? cn=C01. [in Chinese]. Beijing: National Bureau of Statistics. http:/ / data.stats.gov.cn/easyquery.htm?cn=C01.

Swanson, Ana. 2017. "Trump Administration Unveils Goals in Renegotiating NA FTA." Washington Post, July 17.

U SITC (Us International Trade Commission). n.d. Interactive Tariff and Trade DataWeb. Washington, DC: Us ITC. https://dataweb.usitc. gov/.

U st R (Office of the United States Trade Representative).2017. Summary of Objectives for the N A FTA Renegotiation. Washington, D C: USTR. U s T R (Office of the United States Trade Representative). 2017. Upgrading the North American Free Trade Agreement (N A F TA). Washington, DC: USTR.

Villarreal, M. Angeles, and Ian F. Fergusson. The North American Free Trade Agreement (NAFTA) (CR S Report R42965). Washington, D C: Congressional Research Service.

Wei, Hongxia. 2014. China-us Relations in the Frameworks of Multilateral Cooperation in Asia-Pacific. Beijing: China Social Sciences Press. Xinhuanet. 2015. "Xi calls for building common-destiny community on four pillars". Xinhuanet, March 28.

Yang, Zhimin. 2016. "A Political Economy Approach on the Re-negotiation of N A F TA." Journal of Southwest University of Science and Technology (Philosophy and Social Science Edition) 6: 2-8.

Zhang, Yunling. 2018. "Grasp the Trend of the Future of Globalization." [In Chinese.] 《世界知识》[World Affairs] 4. 


\section{Renegotiation of NAFTA: The Paradox of Economic Integration and Political Disintegration}

Cuiwen Wang

The North American Free Trade Agreement (NAFTA), which was the first such agreement in the world to include countries from both the global North and South -Mexico, Canada, and the United Statescame into effect on January 1, 1994. Its positive and negative impacts have been debated for more than 20 years. Hufbauer et al. (2014) summarized six charges voiced by NAFTA critics; ${ }^{1}$ Dussel Peters and Gallagher (2013) presented a detailed introduction and deep analysis of related issues.

This discussion intensified after us President Trump put the agreement on the table for renegotiation. At the beginning of his term in office, by executive order, he initiated a process to renegotiate or even abolish NAFTA in accordance with Article 2205, with the aim of ensuring US national interests. Although support for renegotiation of NAFTA did not start in the Trump administration, it is clear that Trump's statements and actions have pushed North American integration toward a different direction. This has caused serious confrontations between the three governments and uproar in the international community.

1 These charges were that NAFTA fostered a growing us trade deficit; trade with Mexico raised us unemployment; job losses depressed us wages, especially in manufacturing; the boom in US agricultural exports turned rural Mexicans into illegal immigrants; NA FTA abetted illegal immigration; and Mexico has not achieved the growth rate anticipated by NAFTA. 


\section{Insights from the field of international relations}

Conventional economic approaches have defined economic integration in terms of different stages of market opening and political coordination, varying from free trade area to customs union, common market, and complete economic union. Economic integration is therefore understood as the removal of trade barriers and the development of centralized coordination with common policies. In fact, the processes and forms of regional integration are more complicated and diversified. Gilpin (2001:343) pointed out that North American regionalism has been more mixed than the corresponding process in Western Europe, motivated primarily by political considerations.

In addition to the differing mix of political and economic goals, regional arrangements vary in their institutional form. International relations theory contributes several perspectives from which NAFTA, its renegotiation, and economic integration in general can be viewed.

\section{The realist perspective}

The realist approach to economic regionalism calls attention to several factors that limit peaceful economic and political integration. Grieco (1997), for example, highlights that these inevitably make the type of long-term cooperation necessary to integration efforts very difficult to achieve. Realists' concern about relative gains stems from their view that stressed the importance of relative gains and of distributive issues in state calculationnal relations is a zero-sum game, in which one group's gain equals another group's loss.

Reducing the us trade deficit has become a key pillar of President Trump's policy. Trade deals pursued by the United States are "trade balance agreements" rather than free trade agreements. The reduction of trade deficits with several key countries has been the primary goal of the aggressive us trade policy. It is common for the us government to prioritize American interests in Us trade negotiations, but the current 
Us trade approach has an obsessive concern about bilateral trade balances and narrow special interests in the United States, as opposed to broader national and regional interests (Bergsten 2017:2). Such an approach leads to managed trade instead of pure trade liberalization, and increases the chance of a trade war. In the NAFTA renegotiation, managed trade rather than free trade is reflected in Us negotiating positions such as those targeting auto imports and refined sugar, which may involve rules of origin and export restrictions. Therefore, the trade policy of the Trump administration reflects a mercantilist approach anchored in economic nationalism.

The realist perspective assumes that a successful process of economic and political integration must be championed by one or more core political entities that are willing to use their power and influence to promote the integration process. However, there have been complaints that NAFTA cost millions of Us jobs, suppressed wages, and deepened US economic inequality. The main purpose of us participation in the negotiations was to revise the economic and trade cooperation framework, reduce the us trade deficit, and reduce the loss of U s manufacturing jobs (Bergsten 2017:14). Since the Mexican economy is less than one-tenth the size of the Us economy, it is not plausible that trade integration could dramatically shape the giant us economy, even though integration could exert a substantial impact on the relatively small Mexican economy (Hufbauer et al. 2014:4).

The trade deficit should be understood from the perspective of multilateralism rather than bilateralism. As far back as the negotiations of NAFTA more than twenty years ago, economists have calculated the relationship between the loss of jobs under trade protection and the loss of consumer benefits. Negative effects claimed by US NA F TA critics, such as larger trade deficits and higher unemployment, are seldom observed in real life. ${ }^{2}$ As Gilpin noted, a country's unemployment

2 A study by Hufbauer and Elliot (1995), in the context of the bitter controversy over the ratification of NAFTA, found that past protection of 21 American industries had actually saved few jobs and that the cost to consumers had been approximately $\$ 170,000$ per job saved. The equivalent figure for Japan is $\$ 600,000$. 
rate is determined principally by its macroeconomic policies. In a well-functioning economy, trade does not decrease or increase unemployment. While NAFTA has not affected the number of jobs in the Amercan economy, it has redistributed jobs from one economic sector or region to others. (Gilpin 2001:206)

Understanding economic integration from a realist perspective inevitably involves the distribution of gains. It was expected that free trade could bring stronger and more stable economic growth to Mexico, provide new employment opportunities, and stop Mexican illegal immigration (McBride and Sergie 2018). Two decades after NAFTA's establishment, Mexican economy is highly dependent on the United States $^{3}$ with the characteristics of political vulnerability of interdependence. Mexican immigration to the United States rose from 3.5 million in 1995 to 11.1 million in 2016 (de la Garza 2013; Passel and Cohn 2016).

\section{The liberal-institutional perspective}

Liberalism emphasizes the ability of international institutions to promote cooperation. From the liberal-institutional perspective, integration should be based on the nature of a model of NAFTA and its operational mechanism. NAFTA was signed, as Pastor (Pastor 2001:96) wrote, like a "business contract" between corporations, basing the three countries' relationship entirely on commerce; the additional statutes on the enforcement of environmental laws and workers' rights are only a pledge in response to critics, added by the negotiators to the original "contract". The process of ratification and negotiation of NAFTA was "a 'trade obsessed' process that generally ignored serious questions of adjustment to the full implications of economic globalization" (Schmidt 1996:69). This agreement model leaves little room for further deepening of the

3 For example, in 2000 Mexico sent 88.7 percent of its domestic production to the United States market; $73.1 \%$ of Mexican imports were from the United States (Hanson 2003). 
relationship because it is nothing other than a contract in which other social and political aspects are not considered.

NAFTA focused on economic cooperation, and most of the provisions are intended to settle trade disputes. Free trade promotes personal exchanges, but NAFTA does not provide a cooperative institution to manage immigration. This deterioration of Mexico-us immigration and makes it difficult to prevent increasing immigration by people searching for a better living.

Integration in North America is occurring on two parallel lanes, economic and social/political. Economic integration has largely been accomplished, but social and political integration seem almost unachievable. Some analysis has indicated that NAFTA is quite different from other integration schemes. Without the support of any real supranational institution, economic integration has not, in over 20 years, "spilled over" to political integration.The major reason for this lack of institutionalization is probably that, as a world power, the United States is reluctant to be constrained and cede power within an institutional framework. For the United States, a bilateral context provides greater relative power, while a supranational institution would limit its authority. The great disparities of economy between the three countries also hinder the creation of a solid institutional framework for the agreement.

\section{The constructivist perspective}

It is worth taking a deeper look at the lack of a supranational institution governing NAFTA. In social constructivist theory, the physical characteristics of two countries' relationship, such as geography and economic trade, construct the relationship between them but do not encompass the impacts they have on each other, as ideas and beliefs have more significance in their bilateral system (Wendt 1994).

Communities are almost nonexistent in the NAFTA framework, and economic integration appears to proceed on the basis of policy convergence, which results in the acceptance of common norms by the 
governments of the three countries. The idea of a community is based on the establishment of common cooperative goals in diverse areas, such as infrastructure, immigration, development, education, and security, and on the formation of institutions that indicate the achievement of said objectives. It has been suggested that following the model of integration that led to the European Union, North America could also develop into a North American Community, whose people have a clear regional identity in addition to their national identities (Pastor 2001,95).

However, the people of these three countries do not appear to identify with each other. This is especially true for Mexicans. In a poll carried out by the Mexican Center for Research and Teaching in Economics, fewer than 7 percent of respondents said they perceived Mexico as having a North American identity, while 55 percent saw Mexico as having a Latin American identity. Over 60 percent of the Mexican population has expressed distrust toward their northern neighbors, and only 25 percent said they trust the United States (El Imparcial 2018). The historic roots of the love/hate relationship between Mexico and the United States, and Mexican nationalism and pride, make it seem almost impossible to think of the North American region as a community with shared values, pursuing common objectives. In spite of the large numbers of Mexican immigrants to the United States, both legal and illegal, there seems to be little improvement in mutual understanding between the two peoples. Given President Trump's disdain for Mexico and NAFTA, which he has frequently called the worst deal ever, the notion of a community, with a shared sense of belonging and identity, seems implausible.

\section{The impact of China and the improved China-Mexico relationship}

China's economic rise and its increased outreach to the rest of the world are profoundly changing the structure and course of international political and economic systems. With the onset of twenty-first century, 
the strengthening of economic ties marks the most prominent aspect of Sino-Latin American relations. Comparing to complementary relations between China and South America, The competitiveness of China's relationship with Mexico is under scrutiny. Gallagher and Dussel Peters (2013) noted that NAFTA trade has been affected by increasing Chinese trade within the region, even though China is not a member of NAFTA. Some have argued that the competition Mexican goods face from China was not limited to the domestic market but also extended to the markets of Mexico's main trading partners in N A FTA and the Pacific Alliance (Ramirez Bonilla and Haro Navejas 2014).

Policymakers in China and Mexico are clearly aware of the challenges posed by the structure of trade and investment between the two partners. With the end of the commodity boom cycle, both China and Mexico entered the dual transformation of slower economic growth and economic restructuring. The main driver of China's economic growth engine is gradually changing from foreign capital and foreign trade to domestic demand. In addition, given the sustainability of China's economic growth and the huge market demand it generates, the transformation of China's economic model will bring new opportunities to its trading partners. China is building a new model of cooperation. Its foreign economic policies put more emphasis on mutual benefit.

China's One Belt and One Road initiative underlines its push to take a larger role in global affairs. In July 2014, the Chinese government proposed a new " $1+3+6$ " cooperation framework between China and Latin America. ${ }^{4}$ It is apparent that China is striving to build a mutually

4 China proposes to jointly build a new " $1+3+6$ "cooperation framework. " 1 "means "one plan", referring to the establishment of the China-Latin American Countries and Caribbean States Cooperation Plan (2015-2019) with the aim of achieving inclusive growth and sustainable development. " 3 " means "three engines", referring to promoting the comprehensive development of China-Latin America practical cooperation with trade, investment and financial cooperation as the impetus, striving to promote China-Latin America trade to scale up to 500 billion USD and the investment stock to Latin America up to 250 billion USD within ten years and promote the expansion of local currency settlement and currency swap in bilateral trade. "6" means "six fields", referring to boosting China-Latin America industry connection with energy and resources, infrastructure construction, agriculture, manufacturing, scientific and technological innovation, and information technologies as cooperation priorities. 
beneficial, sustained relationship through such actions as enhancing regional infrastructure and nurturing Latin American and Caribbean countries' internal capacity for development. In a recently released policy paper on Latin America and the Caribbean, China raised the idea of "upholding both justice and interests," with a view to achieving mutual benefits in the region, stressing the spill-over effects of new cooperation (e.g. on infrastructure) for development (Huang 2016:3209). China and Mexico are transcending the traditional mode of labor division in pursuit of a new relationship based on equality and mutual benefit, which sets a new example of South-South cooperation.

China has attached unprecedented importance to Latin America in its diplomatic strategy in the last decade. Chinese President Xi Jinping has made three trips to Latin America over the past years, while President Trump has not yet visited the region. Some observers have asserted that the United States has neglected Latin American affairs because Latin America does not have high priority in us global strategy. As NAFTA was renegotiated, some observers noted that Mexico was looking for new options. As American foreign policy moves toward protectionism and mercantilism, Mexico needs to seek options that reduce its own vulnerability. The July 2018 presidential election in Mexico is seen as a result of Mexico's turn to a new direction in which it will more actively pursue foreign affairs goals.

\section{Goodbye NAFTA, hello USMCA}

After more than a year of intense negotiations, the United States, Canada, and Mexico reached an agreement to update NA FTA at the end of September 2018. Most of the key provisions do not become effective until the legislatures of the three countries approve the agreement. In the new deal, the United States and Canada both have victories. One observer called the deal a "mashup between the old NAFTA and the new T P P which Trump withdrew the United States” (Gies 2018). 
The new agreement has a new name: the U.S.-Mexico-Canada Agreement (USMCA). It makes a number of significant upgrades to environmental and labor regulations, especially regarding Mexico, and strengthens intellectual property regimes. But it does not go far enough to remedy N A F TA's shortcomings. It lacks provisions to safeguard indigenous rights through consultations.

USMCA increases the percentage of car parts that must be manufactured in North America from 62.5 to 75 percent. It is also expected to help ease outsourcing in the auto industry by requiring 45 percent of vehicle parts to be manufactured by workers earning at least $\$ 16$ per hour, which is well above the average rate for Mexican auto workers (Levin 2018). The deal will likely threaten small farmers, though there could be wins for Mexican workers, including auto workers, with better wages and collective bargaining rights. It is not hard to see why the three countries hurried to sign the new agreement before outgoing Mexican President Enrique Pena Nieto leaves office.

\section{References}

Bergsten, Fred C. 2017. "Trade Balances and the NA FTA Renegotiation." Washington: Peterson Institute for International Economics: 17-23.

De la Garza, Rodolfo O. 2013. "Operation Gatekeeper: The Rise of the 'Illegal Alien' and the Making of the U.S.-Mexico Boundary by Joseph Nevins." Political Science Quarterly 118(2):339-342.

Dussel Peters, Enrique, and Kevin P. Gallagher. 2013. "NA FTA'S Uninvited Guest: China and the Disintegration of North American Trade." cepal Review 110: 83-108.

El Imparcial.2009. “'Hacia una comunidad norteamericana?”, August 30. 
Gallagher, Kevin P., and Enrique Dussel Peters. 2013. "China’s Economic Effects on the U.S.-Mexico Trade Relationship: Towards a New Triangular Relationship?" China and the New Triangular Relationships in the Americas: China and the Future of U S-Mexico Relations, edited by Enrique Dussel Peters, Adrian H. Hearn, and Harley Shaiken, 13-24. Center for Chinese-Mexican Studies/unam, University of Miami and Center for Latin American Studies/U C S : Mexico.

Gies, Heather. 2018. "NA fTA Out, Usmca In: What's in the Canada, Mexico, us Trade Deal?" Al Jazeera, October 2.

Gilpin, Robert. 2001. Global Political Economy: Understanding the International Economic Order. Princeton, NJ: Princeton University Press. Grieco, Joseph. 1997. "Systemic Sources of Variations in Regional Institutionalization in Western Europe, East Asia, and the Americas." In The Political Economy of Regionalism, edited by Edward D. Mansfield and Helen V. Milner, New York: Columbia University Press.

Hanson, Gordon H. 2003. What Has Happened to Wages in Mexico Since NAFTA? NBER Working Paper 9563. Cambridge, MA: National Bureau of Economic Research Huang, Yiping. 2016. "Understanding China’s Belt \& Road Initiative: Motivation, Framework and Assessment." China Economic Review 2016, 314-320.

Hufbauer, Gary Clyde, Cathleen Cimino, and Tyler Moran. 2014. NA FTA at 20: Misleading Charges and Positive Achievements. Washington, DC: Peterson Institute for International Economics.

Hufbauer, Gary Clyde, and Kimberly Ann Elliott. 1995. "Measuring the Costs of Protection in the United States." European Journal of Political Economy 11(3): 609-612.IMF (International Monetary Fund). 2017. World Economic Outlook 2017. Washington, DC: IMF.

Levin, Sander M. 2018. Us ITC Hearing on the United States-MexicoCanada Agreement. November 15. Washington, DC: US ITC.

McBride, James, and Mohammed Aly Sergie. 2018. NAFTA's Economic Impact. New York: Council on Foreign Relations.

Passel, Jeffrey S., and D'Vera Cohn. 2016. Overall Number of U.s. Unauthorized Immigrants Holds Steady since 2009. Washington, DC: Pew Research Center. 
Pastor, Robert A. 2001. Toward a North American Community: Lessons from the Old World for the New. Washington, DC: Institute for International Economics.

Ramírez Bonilla, Juan José, and Francisco Javier Haro Navejas. 2014. "Mexico-China Relations in a New Era of Regional Integration." In Latin America, the Caribbean and China: Sub-regional Strategic Scenarios, edited by Adrián Bonilla Soria and Paz Milet García, 191-238. San José, Costa Rica: Facultad Latinoamericana de Ciencias Sociales 2014.

Schmidt, Arthur. 1996. "Globalization, Neoliberal Ideology, and National Identity: The Historical Uncertainties of N A FTA." Caribbean Studies 29(1): 67-105.

Wendt, Alexander. 1994. "Collective Identity Formation and the International State." American Political Science Review 88(2): 384-396. 



\section{How China, Mexico and U.S. Relations Explain the $21^{\text {st }}$ Century: Transnational Policy Linkages of Trade, Migration and Remittances}

Raúl Hinojosa-Ojeda

The dynamics of the relations between China, Mexico and the United States will be of critical importance in the $21^{\text {st }}$ century given their powerful influence on the world economy, which is undergoing a highly challenging transformation of the interdependence between what we now call "developed" and "developing" countries.

Figure 1. Global GDP shares of countries currently considered "developed" and “developing”, from year 1 to 2050. (G D P in Purchasing Power Parity)

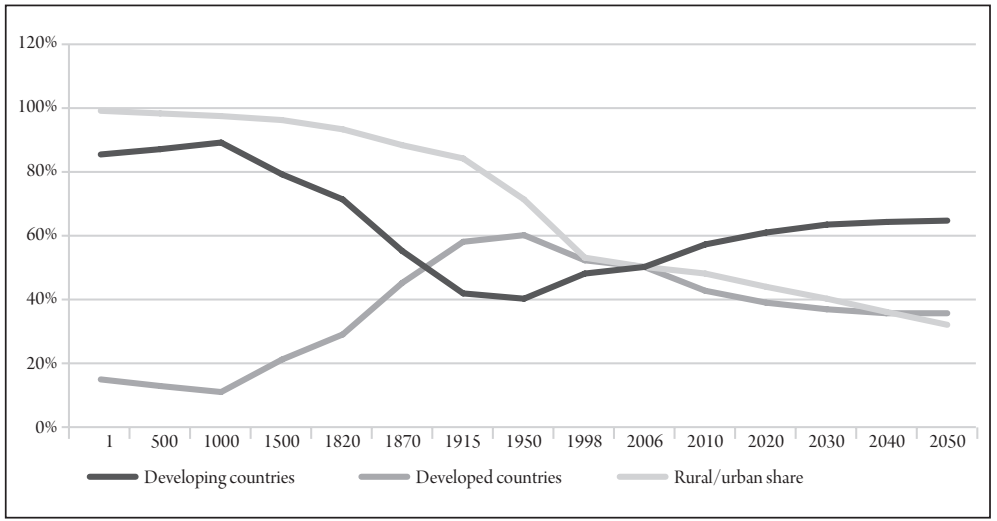

Data sources: Bolt and van Zanden (2014) and Ritchie and Roser (2018). GD P shares are estimations made by the UCLA NAID Center. 
Since about 500 years ago, the world economy began undergoing a "Great Divergence" (Pomeranz 2000), during which the countries that are currently considered "developed" began to obtain better economic results and eventually overtook the countries now known as "developing" as a share of global income. In the $21^{\text {st }}$ century, however, a transition is occurring that could be called a "Great Convergence" in which the sum of economic activity (in terms of purchasing power parity) within developing countries, which represented the majority of production before 1500 , is once again regaining the historic leading position. This renewed geo-distributional transformation is being notably accompanied by a dramatic acceleration of mass migrations from diminishing rural to booming urban areas within and between countries (see Figure 1).

\section{The Great Convergence and the North's Nationalist Backlash}

The emergence of the Donald Trump and Brexit nationalist narratives in the context of the apparent inevitability of this new global convergence raises a fundamental question: can the evolution of this Great Convergence be seen as beneficial to both developed and developing countries or will it be a source of inevitable global conflict between them? Given the immense stakes, it is essential that President Trump's nationalist arguments receive serious and critical academic analysis. A fundamental starting point is the "Trump Paradox" which identifies a fundamental disconnect between Trump's anti-China and anti-Mexico rhetoric and an actual local exposure of Trump's political base to economic impacts due to U.S. relations with China and Mexico through trade and migration (Hinojosa-Ojeda, Wynn, and Chen 2016).

Developing a theoretical and policy praxis to address the Great Convergence will require comprehensive methodologies to model actual impacts of U s, China Mexico inter-relations and develop policy options for building mutually beneficial relationships between developed and developing countries. This chapter reports on the results of some studies 
(Hinojosa-Ojeda, Thierfelder, and Robinson 2017) that created general equilibrium models involving multiple countries, and in particular on a model of the relations between the United States, China, and Mexico in the global context. Our work with these models suggests that there are indeed very significant opportunities for mutual benefit within the Great Convergence and that a focus on coordinated migration and remittance reform within North America and China would actually be much more beneficial than continued focus on international trade policy reform between countries for harnessing and addressing the challenge of both growth and equitable distribution.

Since the 1980s, much focus has been placed on trade policy reform, especially on sharp reductions in tariffs, which led to intense transnational integration in production value chains as well as profound nontariff trade reforms negotiated within the World Trade Organization. The economic impact of future trade liberalization negotiations, however, is likely to be less than the potential economic impact of improved migration and remittance policies across borders. Significant migration and remittances reform could do much more to reduce inequality and improve the well-being of many people who are linked together in China, the United States and Mexico. Immigration reform is needed not only for the undocumented in North America, but also for millions in China who are also undocumented (for example, who do not have the residency papers required under the hukou system); it is estimated that there are more than 200 million undocumented people in China. This is of course a much larger number compared to 11 million undocumented in North America, including a growing number of Chinese. Given the very large number of workers involved in migration (both documented and undocumented), what North American countries and China do about immigration reform will have a fundamental impact on the pace and distributional paths of the Great Convergence.

The Great Convergence has already resulted in a massive shifting up of more than 20 points in 20 years of the relative contribution to world GDP by developing countries compared to developed countries (see Figure 1). The emergence of China in relation to the economic size of 
Figure 2. GDP share of specific global regions from year 1 to 2016

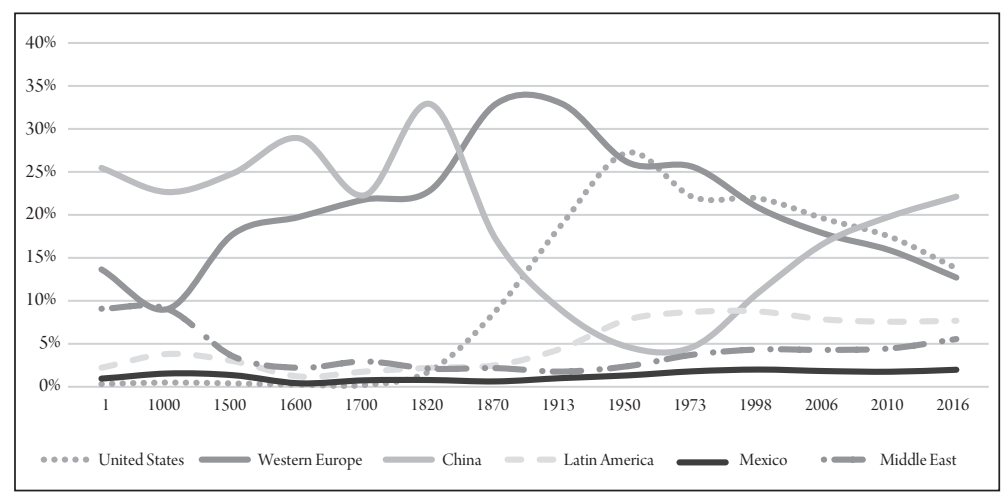

Data source: Bolt and Zanden (2014).

Europe and the United States is a fundamental part of this new dynamic (see Figure 2). In that sense, Donald Trump and others are right in asserting that radical changes have occurred worldwide (Autor, Dorn, and Hanson 2016). However, it is important to understand the relationship between these global shifts and their real significance for the formulation of international trade, migration and remittance policies. It is in this context that we need to analyze the political phenomenon of Donald Trump and the Brexit movement and the construction of alternative policy response for the age of the Great Convergence that can lead to a sustainable and equitable economy and society in the $21^{\text {st }}$ century.

Globalization, defined as the proportion of cross border trade, investment and migration in world GDP, has undoubtedly grown in recent decades to levels not seen since the turn of $19^{\text {th }}$ to $20^{\text {th }}$ century. In this sense, Globalization 2.0 is now much greater than it was during Globalization 1.0 in the decades before the First World War 100 years ago (Ortiz-Ospina and Roser 2018). Migration has also grown dramatically again within Globalization 2.0, with the United States projected to continue immigration growth that will feed the already advanced and profound ethno-racial (non-white) transformation of the U.S. population (see Figure 3). 
Figure 3. Foreign-born population in the United States, 1850-2050

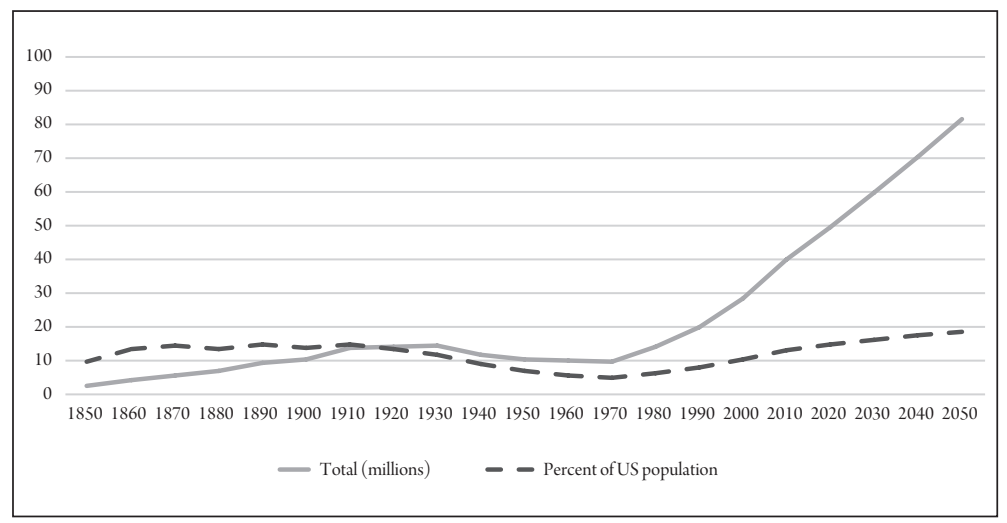

Data sources: López et al. (2018). U.s. Census Bureau. Projections made by NA ID Center.

During this emergence of Globalization 2.0, there has also been a sharp increase in inequality in the United States. A key economic and political question is how U.S. inequality must be viewed within the context of global inequality (Piketty and Saez 2007). In recent years there has been great interest in the explosive growth of the highest income segments of the world economy but also the highly significant growth of a massive emerging global middle class (Milanovic 2016). In the world population as a whole, while the number and incomes of wealthy people has definitely grown, much more income growth has been generated by the new middle classes in countries like China, which have also grown in size compared to the United States middle classes. While the mass of incomes of the US middle class is clearly also continuing to grow, the rate of increase is not as fast as for the middle classes of developing countries.

\section{The Trump Nationalist Narrative and Paradox}

This combination of trends has led Trump and others (from both the left and the right) to suggest that globalization is the cause of the us middle 
class ceasing to grow and even shrinking. The Trump/Bannon racialized nationalist narrative (Woodward 2018) weaves together a tale whereby the United States is losing its dominant position in the world economy due to booming trade and migration from non-white countries which is leading to stagnating white incomes as white are becoming a ethno-racial minority within the U.S. Based on this narrative, Trump's constructs extreme neo-nationalist policy responses calling for building walls and creating new trade protectionism.

Interrogating this racialized nationalist narrative and associated policies exposes a set of serious falsehoods and contradictions. The fundamental Trump Paradox is that in the areas where Trump received the most votes in the 2016 presidential election, international trade and migration actually have the least impact on income levels and oncome inequality. Our research shows that there is a in fact a strong negative correlation between the areas that voted for Trump and the presence of Mexicans in those areas (Hinojosa-Ojeda, Wynn, and Chen 2016). Of the counties in which Donald Trump won the majority of votes, only $2 \%$ percent have a "very high" presence of foreign born non-naturalized Mexicans or Latinos. In addition, the people who voted for Donald Trump are also far less likely to have experienced the effects of competition from Mexican and Chinese imports compared to other regions. Regions that voted for Trump are indeed suffering economically, but trade and migration are neither the cause nor the solution

Ironically, and by contrast, the counties constituting the "Trump's base" are actually very dependent on exports to Mexico and China (representing over $60 \%$ of soy and corn production concentrated in the U.s. Midwest). In direct contradiction to the Trump narrative, the counties of highest immigration and highest trade exposure with Mexico and China were actually the counties least likely to support of Trump and in fact constitute the "base of the Democratic resistance." This contradictory dynamic associated with the rise of Trump can also be found with the Brexit phenomenon. Like in the United States, the areas in the United Kingdom that voted in favor of Brexit were actually areas with less migration and trade (Taylor 2016). 
Exposing the contradictions of the Trump Paradox also points to the need for a comprehensive political economy analysis of the distributive impacts and policy implications of complex interrelationships between trade and migration between the United States and Mexico, as well as between and within China. Data collected for our China-MexiCo-US CGE models indicate that migrations are much more significant than trade in transforming the standard of living in Mexico, the United States, and China. The us trade relationship with China, for example, has less influence on Us economic dynamics than the strong positive effect of immigration (see Figure 4). In fact, the contribution of undocumented immigration to the U.S. GDP is much more significant than the contribution of trade with Mexico and China combined. Instead of causing the country's welfare to deteriorate, immigration is one of the key pillars sustaining U.S. economic growth going forward, and it has been throughout the history of this "nation of immigrants".

\section{Figure 4. United States GDP generated by immigrants compared to the value of trade (2015)}

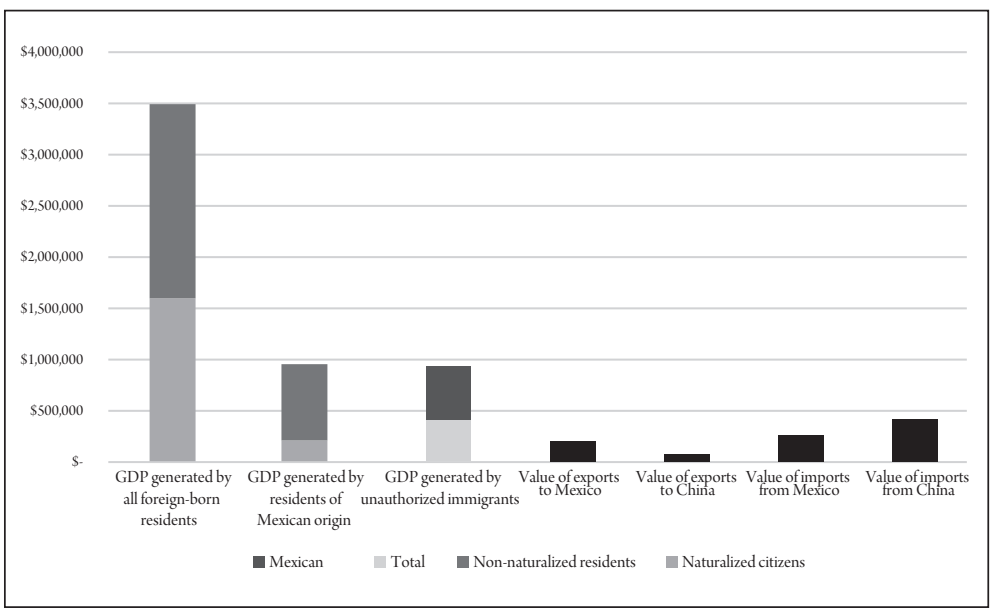

Data source: UCLA NAID Center estimates based on American Community Survey data. 


\section{Transnational Policy Options for the Great Conversion}

Within the complex dynamics of the Great Convergence, developments in China, Mexico and the United States could be viewed in terms of the comparative evolution of the Kuznets curve in each country and their interconnections. The Kuznets hypothesis states that inequality grows in lower income societies, with inequality increasing associated with income growth of initial industrialization and rural outmigration which peaks at a certain level whereby inequality will start to decrease again. Migrations within China as well as between Mexico to the United States are actually very similarly following these Kuznet trends since in both cases migrant-sending areas are predominantly rural. Migrations within China and between Mexico and the U.S. are also both reaching the peak level within what is called the "first" Kuznets curve of inequality associated with industrialization and the displacement of agriculture. While inequalities are beginning to decline in these developing countries, as they did in the U.S. and the UK previously, the U.S. and U.K. are now seen as entering a "second" Kuznets curve, which has much more to do with the increased use of labor-saving technology in a technology-based service economy. For Milanovic (2016), this explains the reemergence of the growth of inequality in developed countries and the future dynamics of global inequality. A key question is what these Kuznet curve dynamics tell us about the future interdependence of income growth between middle income groups in the North and their continued emergence in the South. Furthermore, we need to understand how this global interdependence of middle-income groups both impacts, and can be impacted by, trade and migration trends and policies.

As a part of the Great Convergence, there has clearly been a displacement caused by China entering the world trading system, often referred to as "China shock". Meanwhile, United States trade with China has displaced trade with Mexico, which has had a great impact on the MexicoUnited States trade and labor market relationships. The impact of this China shock, however, has now been largely absorbed throughout all 
three economies. The key question going forward is: what are the key factors driving future dynamics of interdependence between Mexico, United States, and China, such as the growing importance of migration within and between these countries? To what extent are the massive migration dynamics within China changing the dynamics between Mexico and the United States? What are the implications of these trends for the future course of the Great Convergence?

A historical analysis of the Great Divergence shows massive outmigration in countries such as England and the Netherlands, which had low levels of welfare at the beginning of the $17^{\text {th }}$ century through part of the $19^{\text {th }}$ century. During this period, as European countries were exporting migrants until such time that industry overtook agriculture as a share of employment, inequalities within and between countries were growing. After industrialization, out migration was substantially reduced as was inequality. Extrapolating this analysis to the case of Mexico, we observe a similar peaking of outmigration once a similar agriculture-to-industry shift has been reached. In China, meanwhile, massive outmigrations are still exiting from rural areas to urban areas and abroad as industry has yet to overtake agriculture employment. It is crucially important to take this phenomenon into account due to the determining role of migration in the future development of China and its relation to the world economy.

Research at the UCLA North American Integration and Development Center (Hinojosa-Ojeda 2016) has been tracing these comparative migration trends in North America and China. Since 2001, Mexican net out-migration has declined precisely because of changes in the demographic and economic sectoral structure that have already occurred in Mexico. Furthermore, a greater number of people are beginning to return to Mexico due to aging and retirement. This has significantly reduced the number of unauthorized crossings, apprehension and deportations and the total undocumented population living in the United States. This historical context highlights the futility of the Trump narrative calling for the building of a border wall as a central policy focus.

Concurrently over the last three decades, China has undergone a massive increase on migration both within and out of the country. There 
are currently more Chinese than Mexicans arriving as undocumented in the United States, especially during 2014 (see Figure 5). China is now the number one country remittances in the world (overtaking Mexico), with domestic internal remittances even higher representing a important source of savings and investments for the raising of incomes in migrant sending regions (see Figure 6). The inequalities within China, Mexico and the U s are increasingly linked to the total flows and legal status of migrants as well as migrant remittances within and between countries.

With respect to alternative policy projections going forward, the general equilibrium models used in the studies reported in this chapter show that the impacts of future trade agreements within an already liberalized trading system will minimal compared to the impact of migration reform. Granting the 11 million undocumented immigrants in the United States legal status would be much more economically beneficial than any future trade agreement, as is the case for China. In contrast, the anti-immigration deportation measures that the Trump administration is undertaking constitute one of the most counter-productive decisions that can be made in an immigrant economy such as the United States. Figure 7 shows the projected impacts of a war against migrants, which could be very damaging to the us economy -even more than a trade war between Mexico, China, and the United States.

Figure 5. Undocumented from China and Mexico in the United States, 1990-2014

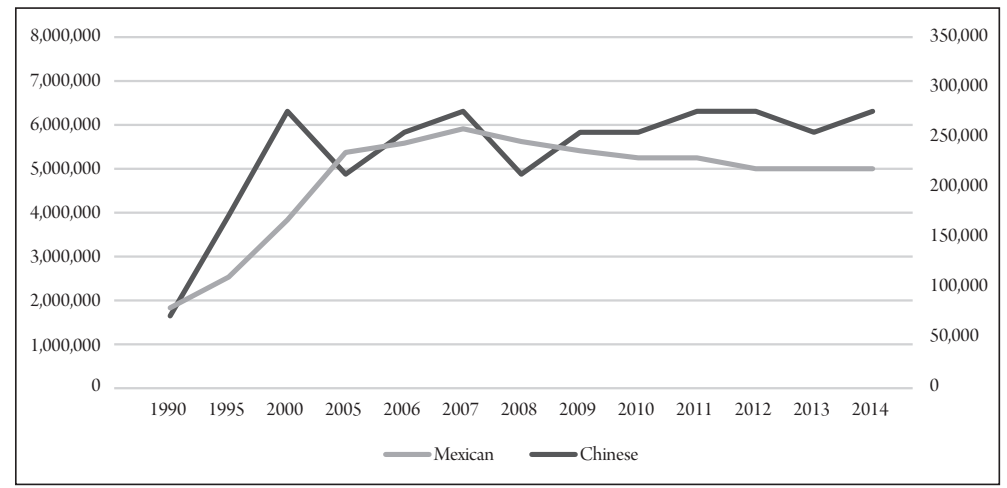

Data source: Pew Research Center (2016). Note: Chines migrants in right axis, Mexican migrants left axis 
Figure 6. Total remittances received in China and Mexico, 1990-2009 (billions of dollars)

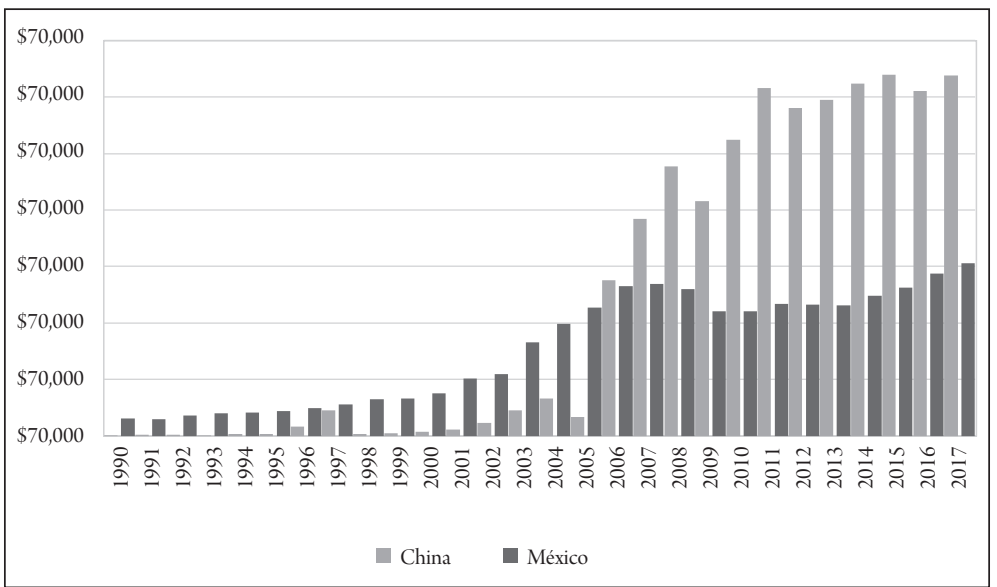

Data source: World Bank (2017).

Figure 7. Projected changes in US GDP under different immigration scenarios, 2009-2019

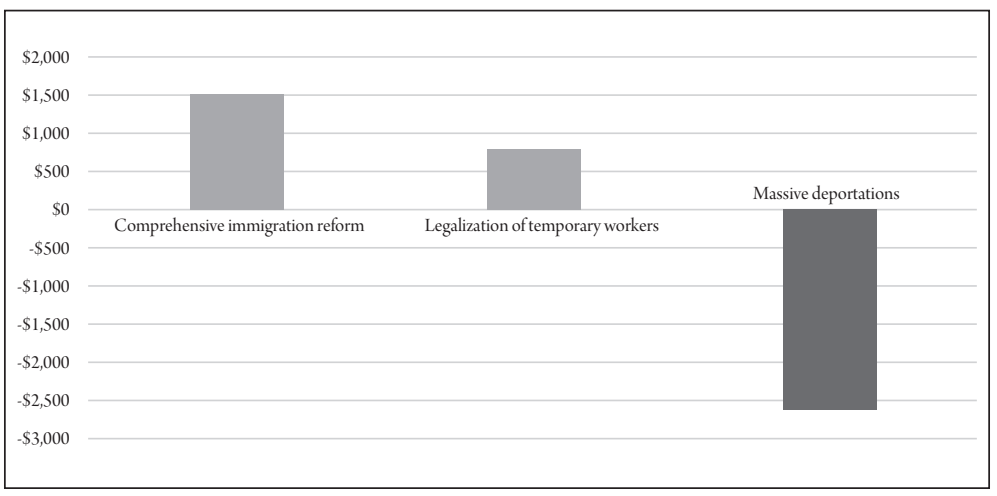

Source: Hinojosa-Ojeda (2013).

This analysis suggests that one of the most interesting and important opportunities in China-North America relations is the potential large impacts of significant hukou reform of the estimated 200 million irregular workers in China. Compared to the very positive impact of U.S. 
legalization of undocumented workers, significant hukou reform would likely have an even more dramatic effect on the Chinese economy. Ongoing technology-led remittance reform in China (such as the use of low-cost WeChat and Ali-Pay platforms) can also significantly increase incomes in migrant sending regions, as could be the case if Mexico were to adopt similar remittance technology reforms. In addition, the legalization of the hukou system and remittance transformations could significantly benefits U.S. exports to both China and Mexico. These two markets represent $70 \%$ of the exported from counties in the U.S. which constitute the base of Trump's political support. Ironically the policy reform path most benefiting the Trump electoral base is not through a trade war but rather through the advocacy of the rights and living standards of Chinese migrant workers, which would have the effect of dramatically increasing the consumption of goods most dependent on soy exports from the U.S. to China (ie., chicken and pork). These Chinese migrant labor and remittance reforms, combined with U.s. legalization, rising incomes of immigrants and Chinese inspired Mexican remittance reform, would result in both rapid GDP, rising wages and decreased inequality in China, Mexico and the U.S.

In conclusion, the answer to the question at the start of this chapter is, yes, there is indeed a strong evidence base for identifying much potential for mutually beneficial convergence between today's developed and developing countries in the $21^{\text {st }}$ Century. In particular, United States, Mexico and China can generate mutually beneficial dynamics of cooperation and reform of migratory processes, the legalization of migration and new remittance technologies which can accelerate trade, GDP and incomes. The benefits from migration and remittance reform can, in actuality, be shown to be significantly greater and can grow income and employment more quickly than the benefits from further trade liberalization. Regional policy discussion between the United States, Mexico and China should therefore place labor market, migration and remittance policies in the center of commercial integration negotiations. 


\section{References}

Autor, David H., David Dorn, and Gordon H. Hanson. 2016. The China Shock: Learning from Labor Market Adjustment to Large Changes in Trade. N BER Working Paper 21906. Cambridge, MA: National Bureau of Economic Research.

Bolt, Jutta, and Jan Luiten van Zanden. 2014. "The Maddison Project: Collaborative Research on Historical National Accounts." Economic History Review 67(3): 627-651.

Hinojosa-Ojeda, Raúl. 2016. No More Border Walls! A Critical Analysis of the Costs and Impacts of u.s. Immigration Enforcement Policy Since irca. Los Angeles: North American Integration and Development Center, University of California, Los Angeles.

Hinojosa-Ojeda, Raúl. 2013. The Cost and Benefits of Immigration Enforcement. Published on: Immigration Reform: A System for the $21^{\text {st }}$ Century. Houston: James A. Baker III Institute for Public Policy, Rice University.

Hinojosa-Ojeda, Raúl, Maksim Wynn, and Zhenxiang Chen. 2016. Donald Trump's False Narrative on Mexican Migration and Trade: A Geopolitical Economic Analysis. Los Angeles: North American Integration and Development Center, University of California, Los Angeles. Hinojosa-Ojeda, Raúl, Karen Thierfelder, and Sherman Robinson. 2017. NA F T A and Immigration: Linked Labor Market and the Impact of Policy Changes on the U.S. Economy. Manuscript submitted for publication. López, Gustavo, Kristen Bialink, and Jyannah Radford. 2018. Key findings about U.s. immigrants. Washington, DC: Pew Research Center. http://www.pewresearch.org/fact-tank/2018/09/14/key-findingsabout-u-s-immigrants/

Milanovic, Branko. 2016. Global Inequality: A New Approach for the Age of Globalization. Cambridge, MA: Harvard University Press.

Ortiz-Ospina, Esteban, and Max Roser. 2018. “International Trade.” In Our World in Data. https:// ourworldindata.org/international-trade. 
Pew Research Center. 2016. Unauthorized Immigrant Population Trends for States, Birth Countries and Regions. Washington, D C: Pew Research Center. http://www.pewhispanic.org/interactives/unauthorizedtrends/

Piketty, Thomas, and Emmanuel Saez. 2007. The World Top Incomes Database. https://wid.world/country/usa .

Pomeranz, Kenneth. 2000. The Great Divergence: China, Europe, and the Making of the Modern World Economy. Princeton, NJ : Princeton University Press, 2000.

Ritchie, Hanna, and Max Roser. 2018. Urbanization. Published online at OurWorldInData.org Retrieved from: https: / ourworldindata.org/ urbanization [Online Resource]

Taylor, Adam. 2016. "What a Real 'Brexit Britain 'Would Look Like." Washington Post, June 29.

U.S. Census Bureau. Current Population Survey (C PS): Foreign Born. https://www.census.gov/topics/population/foreign-born/data.html

Woodward, Bob. 2018. Fear. Trump in the White House. Cammeray: Simon and Schuster.

World Bank. 2010. Remittances Data. Development Prospects Group. Washington, D C: World Bank. 


\title{
Modernizing NAFTA: Transformation, Negotiation, and Unequal Results
}

\author{
Clemente Ruiz Durán
}

The North American Free Trade Agreement (NAFTA) is a product of globalization in a world of multilateral institutions that pushed the United States away from the bilateral agenda of the $20^{\text {th }}$ century, thanks to the rules of the World Trade Organization, which replaced the General Agreement on Trade and Tariffs regime. New rules enabled an expansion of world trade, reaching u s $\$ 17.43$ trillion of exports in 2017, nine times the trade of 1980 (w To 2018). Multilateral agreements led to the transformation of trade, enabling greater participation by developing countries and reducing the postwar hegemony of the United States, whose share of world trade has dropped from 28 percent in 1948 to barely 9.6 percent today. Under the new rules, Europe and Asia emerged as the stars of trade; today they represent two-thirds of world exports.

This transformation affected not only trade but also production, which moved from national to global value chains, relocating production facilities to take advantage of world surplus labor. This changed the role of national economies, reduced the scope for action of public policy, empowered transnational corporations, and hurt labor through the relocation of plants and the reduction of labor standards.

In 2016, us presidential candidates opened a debate about NA FTA, demanding reshoring of businesses that had opened plants abroad and an increase of labor standards in trading partners to avoid a continuous 
erosion of workers' earnings. In 2017, in his inauguration speech, Us President Donald Trump demanded new trade rules in the pursuit of his goal to "make America great again." The new strategy has focused on the practice on the abandonment of multilateral bargaining and on empowering bilateral agreements, based on the assumption that pushing to the edge could bring back the old days of us prevalence in the trade arena; but the world has changed, and this change could not be reversed as expected.

\section{Transforming the regional economy}

Bringing a developing economy (Mexico) into NAFTA was intended to take advantage of excess labor to help bolster u s economic competitiveness, so it was reasonable to assume that a trade imbalance would emerge as low-wage inputs were going to be produced in Mexico and incorporated into final goods in the United States. Success of intermediate goods exports were followed by final goods, at a lower cost that the prevailing in US markets, increasing purchasing power of American families. To push regional production and avoid the multiplier effect to deviate to other sourcing regions with the emergence of global value chains (GVCs), the agreement established in the nineties rules of origin to promote regional integration, for example, the auto industry fixed a rule of origin of 50 percent of local content

As result of the agreement, trade among N A F TA members multiplied 3.5 times from 1994 to 2016 (Table 1), resulting in a trade surplus for Mexico and Canada and a large deficit for the United States, as would be expected based on development theory (Prebisch, 1986).

NAFTA, through sourcing for global value chains, also benefited other regions, mainly Europe and East Asia. The largest impact was on China; its exports to the region multiplied almost by 20 and its imports by 10 , resulting in a dramatically increased trade surplus with the region, from u s $\$ 7.2$ billion in 1994 to us $\$ 281.6$ billion in 2016 (Table 2). 
Table 1. Trade within the NAFTA region, 1994 and 2016 (millions of dollars)

\begin{tabular}{|c|c|c|c|c|c|}
\hline \multicolumn{6}{|c|}{1994} \\
\hline & Canada & United States & Mexico & Total & $\%$ \\
\hline \multicolumn{6}{|c|}{ Exports } \\
\hline Canada & 0.0 & $126,651.3$ & 772.2 & $127,423.6$ & 36.9 \\
\hline United States & $114,253.0$ & 0.0 & $50,834.2$ & $165,087.2$ & 47.8 \\
\hline Mexico & $1,547.3$ & $51,205.2$ & 0.0 & $52,752.5$ & 15.3 \\
\hline Total exports & $115,800.3$ & $177,856.5$ & $51,606.4$ & $345,263.2$ & 100.0 \\
\hline \multicolumn{6}{|c|}{ Imports } \\
\hline Canada & 0.0 & $100,564.5$ & $3,313.5$ & $103,878.0$ & 30.3 \\
\hline United States & $131,916.2$ & 0.0 & $50,333.5$ & $182,249.7$ & 53.2 \\
\hline Mexico & $1,620.3$ & $54,813.0$ & 0.0 & $56,433.3$ & 16.5 \\
\hline Total imports & $133,536.5$ & $155,377.5$ & $53,647.1$ & $342,561.1$ & 100.0 \\
\hline \multicolumn{6}{|c|}{ Balance } \\
\hline Canada & 0.0 & $26,086.8$ & $-2,541.3$ & $23,545.5$ & $\mathrm{n} / \mathrm{a}$ \\
\hline United States & $-17,663.2$ & 0.0 & 500.6 & $-17,162.6$ & $\mathrm{n} / \mathrm{a}$ \\
\hline Mexico & -73.0 & $-3,607.7$ & 0.0 & $-3,680.7$ & $\mathrm{n} / \mathrm{a}$ \\
\hline \multicolumn{6}{|c|}{2016} \\
\hline & Canada & United States & Mexico & Total & $\%$ \\
\hline \multicolumn{6}{|c|}{ Exports } \\
\hline Canada & 0.0 & $296,607.3$ & $5,761.6$ & $302,368.9$ & 27.2 \\
\hline United States & $265,928.1$ & 0.0 & $230,959.1$ & $496,887.2$ & 44.7 \\
\hline Mexico & $10,432.3$ & $302,862.8$ & 0.0 & $313,295.1$ & 28.2 \\
\hline Total exports & $276,360.4$ & $599,470.0$ & $236,720.7$ & $1,112,551.1$ & 100.0 \\
\hline \multicolumn{6}{|c|}{ Imports } \\
\hline Canada & 0.0 & $210,250.9$ & $25,075.2$ & $235,326.1$ & 23.4 \\
\hline United States & $283,309.1$ & 0.0 & $296,858.2$ & $580,167.3$ & 57.7 \\
\hline Mexico & $9,631.5$ & $179,909.1$ & 0.0 & $189,540.6$ & 18.9 \\
\hline Total imports & $292,940.6$ & $390,160.0$ & $321,933.4$ & $1,005,034.0$ & 100.0 \\
\hline \multicolumn{6}{|c|}{ Balance } \\
\hline Canada & 0.0 & $86,356.4$ & $-19,313.6$ & $67,042.8$ & $\mathrm{n} / \mathrm{a}$ \\
\hline United States & $-17,381.0$ & 0.0 & $-65,899.1$ & $-83,280.1$ & $\mathrm{n} / \mathrm{a}$ \\
\hline Mexico & 800.7 & $122,953.7$ & 0.0 & $123,754.4$ & $\mathrm{n} / \mathrm{a}$ \\
\hline
\end{tabular}

Data source: OECD, Bilateral Trade Database by Industry and End-use.

Note: $\mathrm{n} / \mathrm{a}=$ not applicable. 
Table 2. NAFTA's and China's impact on intra-regional trade, 1994 and 2016 (millions of dollars)

\begin{tabular}{|c|c|c|c|c|c|c|}
\hline \multicolumn{7}{|c|}{1994} \\
\hline & Canada & United States & Mexico & China & Total & $\%$ \\
\hline \multicolumn{7}{|c|}{ Exports } \\
\hline Canada & 0.0 & $126,651.3$ & 772.2 & $1,556.4$ & $128,979.9$ & 34.0 \\
\hline United States & $114,253.0$ & 0.0 & $50,834.2$ & $9,286.7$ & $174,373.9$ & 46.0 \\
\hline Mexico & $1,547.3$ & $51,205.2$ & 0.0 & 100.4 & $52,852.9$ & 13.9 \\
\hline China & $1,396.9$ & $21,474.8$ & 201.5 & 0.0 & $23,073.2$ & 6.1 \\
\hline Total exports & $117,197.2$ & $199,331.4$ & $51,807.9$ & $10,943.5$ & $379,280.0$ & 100.0 \\
\hline \multicolumn{7}{|c|}{ Imports } \\
\hline Canada & 0.0 & $100,564.5$ & $3,313.5$ & $2,823.4$ & $106,701.5$ & 26.5 \\
\hline United States & $131,916.2$ & 0.0 & $50,333.5$ & $41,345.8$ & $223,595.5$ & 55.5 \\
\hline Mexico & $1,620.3$ & $54,813.0$ & 0.0 & 499.4 & $56,932.7$ & 14.1 \\
\hline China & $1,848.7$ & $13,893.7$ & 93.9 & 0.0 & $15,836.3$ & 3.9 \\
\hline Total imports & $135,385.1$ & $169,271.2$ & $53,740.9$ & $44,668.7$ & $403,065.9$ & 100.0 \\
\hline \multicolumn{7}{|c|}{ Balance } \\
\hline Canada & 0.0 & $26,086.8$ & $-2,541.3$ & $-1,267.0$ & $22,278.5$ & $\mathrm{n} / \mathrm{a}$ \\
\hline United States & $-17,663.2$ & 0.0 & 500.6 & $-32,059.1$ & $-49,221.7$ & $\mathrm{n} / \mathrm{a}$ \\
\hline Mexico & -73.0 & $-3,607.7$ & 0.0 & -399.0 & $-4,079.7$ & $\mathrm{n} / \mathrm{a}$ \\
\hline China & -451.7 & $7,581.2$ & 107.6 & 0.0 & $7,237.1$ & $\mathrm{n} / \mathrm{a}$ \\
\hline \multicolumn{7}{|c|}{2016} \\
\hline & Canada & United States & Mexico & China & Total & $\%$ \\
\hline \multicolumn{7}{|c|}{ Exports } \\
\hline Canada & 0.0 & $296,607.3$ & $5,761.6$ & $15,832.3$ & $318,201.2$ & 18.8 \\
\hline United States & $265,928.1$ & 0.0 & $230,959.1$ & $115,775.1$ & $612,662.3$ & 36.1 \\
\hline Mexico & $10,432.3$ & $302,862.8$ & 0.0 & $5,411.3$ & $318,706.4$ & 18.8 \\
\hline China & $27,312.2$ & $385,677.8$ & $32,356.7$ & 0.0 & $445,346.7$ & 26.3 \\
\hline Total exports & $303,672.6$ & $985,147.8$ & $269,077.3$ & $137,018.7$ & $1,694,916.4$ & 100.0 \\
\hline \multicolumn{7}{|c|}{ Imports } \\
\hline Canada & 0.0 & $210,250.9$ & $25,075.2$ & $48,641.7$ & $283,967.8$ & 16.1 \\
\hline United States & $283,309.1$ & 0.0 & $296,858.2$ & $481,717.7$ & $1,061,885.0$ & 60.0 \\
\hline Mexico & $9,631.5$ & $179,909.1$ & 0.0 & $69,520.7$ & $259,061.3$ & 14.6 \\
\hline China & $18,336.8$ & $135,120.1$ & $10,324.7$ & 0.0 & $163,781.6$ & 9.3 \\
\hline Total imports & $311,277.4$ & $525,280.1$ & $332,258.2$ & $599,880.0$ & $1,768,695.7$ & 100.0 \\
\hline \multicolumn{7}{|c|}{ Balance } \\
\hline Canada & 0.0 & $86,356.4$ & $-19,313.6$ & $-32,809.4$ & $34,233.4$ & $\mathrm{n} / \mathrm{a}$ \\
\hline United States & $-17,381.0$ & 0.0 & $-65,899.1$ & $-365,942.6$ & $-449,222.6$ & $\mathrm{n} / \mathrm{a}$ \\
\hline Mexico & 800.7 & $122,953.7$ & 0.0 & $-64,109.4$ & $59,645.0$ & $\mathrm{n} / \mathrm{a}$ \\
\hline China & $8,975.4$ & $250,557.6$ & $22,031.9$ & 0.0 & $281,564.9$ & $\mathrm{n} / \mathrm{a}$ \\
\hline
\end{tabular}

Data source: OECD, Bilateral Trade Database by Industry and End-use.

Note: $\mathrm{n} / \mathrm{a}=$ not applicable. 
Sourcing from other regions diminished the domestic value-added share of gross exports (see Table 3) in Canada, the United States, and Mexico, and increased it in China. Rules of origin have become a key issue in the modernization of NAFTA; in the auto industry, the agreement reached with Mexico sets a goal of 75 percent regional content; today, the proportion is roughly 51 percent according to O ECD estimates.

Table 3. Domestic value-added share (\%) of gross exports for Mexico, the United States, China, and Canada, 1995 and 2011

\begin{tabular}{|c|c|c|c|c|c|c|c|c|}
\hline & \multicolumn{2}{|c|}{ Mexico } & \multicolumn{2}{|c|}{ United States } & \multicolumn{2}{|c|}{ China } & \multicolumn{2}{|c|}{ Canada } \\
\hline Industry & 1995 & 2011 & 1995 & 2011 & 1995 & 2011 & 1995 & 2011 \\
\hline $\begin{array}{l}\text { Agriculture, hunting, } \\
\text { forestry and fishing }\end{array}$ & 94.7 & 89.3 & 92.2 & 88.1 & 92.3 & 89.9 & 85.4 & 83.0 \\
\hline Mining and quarrying & 96.7 & 95.7 & 90.5 & 84.2 & 68.4 & 73.8 & 88.6 & 90.2 \\
\hline $\begin{array}{l}\text { Food products, } \\
\text { beverages and tobacco }\end{array}$ & 85.0 & 83.2 & 91.1 & 86.4 & 67.3 & 74.7 & 80.9 & 79.1 \\
\hline $\begin{array}{l}\text { Textiles, textile products, } \\
\text { leather and footwear }\end{array}$ & 68.4 & 62.5 & 85.1 & 81.7 & 61.1 & 73.5 & 74.8 & 67.4 \\
\hline $\begin{array}{l}\text { Wood, paper, paper } \\
\text { products, printing and } \\
\text { publishing }\end{array}$ & 81.1 & 69.8 & 90.8 & 88.1 & 54.0 & 58.0 & 82.7 & 82.8 \\
\hline $\begin{array}{l}\text { Chemicals and } \\
\text { non-metallic mineral } \\
\text { products }\end{array}$ & 84.3 & 71.9 & 87.9 & 76.4 & 53.1 & 58.6 & 74.1 & 69.0 \\
\hline $\begin{array}{l}\text { Basic metals and } \\
\text { fabricated metal } \\
\text { products }\end{array}$ & 74.9 & 77.5 & 84.3 & 72.8 & 66.1 & 67.5 & 76.1 & 64.2 \\
\hline $\begin{array}{l}\text { hinery and equipment, } \\
\text { nec }\end{array}$ & 67.5 & 62.8 & 84.2 & 76.1 & 61.1 & 69.6 & 71.2 & 65.4 \\
\hline $\begin{array}{l}\text { Electrical and optical } \\
\text { equipment }\end{array}$ & 45.2 & 41.7 & 80.5 & 85.2 & 33.3 & 46.2 & 73.9 & 63.2 \\
\hline Transport equipment & 59.9 & 51.1 & 80.0 & 71.1 & 56.0 & 70.0 & 50.8 & 45.7 \\
\hline $\begin{array}{l}\text { Electricity, gas and water } \\
\text { supply }\end{array}$ & 92.5 & 84.7 & 93.7 & 92.5 & 95.5 & 90.7 & 95.7 & 94.2 \\
\hline Construction & 88.7 & 88.7 & 89.1 & 85.5 & 93.6 & 87.9 & 78.6 & 77.7 \\
\hline $\begin{array}{l}\text { Total Business Sector } \\
\text { Services }\end{array}$ & 95.3 & 94.5 & 95.5 & 94.0 & 96.4 & 93.7 & 92.4 & 90.3 \\
\hline $\begin{array}{l}\text { Community, social and } \\
\text { personal services }\end{array}$ & 94.4 & 95.2 & 95.6 & 93.4 & 95.2 & 92.3 & 91.7 & 92.6 \\
\hline
\end{tabular}

Data source: OECD, International Trade and Balance of Payments, Trade in Value Added (Tiva) December 2016. 
In the development of the regional economy, the service sector has become a key factor. The United States led in the development of the digital economy, quadrupling its surplus in the region in this sector from u s $\$ 10$ million in 1999 to over us $\$ 44$ million in 2013. However, as the digital economy has expanded in Mexico and Canada, the us surplus has declined; it was just under us $\$ 33$ million in 2013 (Table 4).

Table 4. United States trade in services with NAFTA partners, 1999-2017 (millions of dollars)

\begin{tabular}{|c|c|c|c|c|c|c|c|}
\hline \multirow{2}{*}{ Year } & \multicolumn{3}{|c|}{ Mexico } & \multicolumn{3}{|c|}{ Canada } & \multirow{2}{*}{$\begin{array}{l}\text { NAFTA } \\
\text { balance }\end{array}$} \\
\hline & Exports & Imports & Balance & Exports & Imports & Balance & \\
\hline 1999 & 14,174 & 9,688 & 4,486 & 22,868 & 16,598 & 6,270 & 10,756 \\
\hline 2000 & 15,780 & 11,200 & 4,580 & 24,808 & 18,239 & 6,569 & 11,149 \\
\hline 2001 & 16,704 & 10,867 & 5,837 & 24,679 & 17,770 & 6,909 & 12,746 \\
\hline 2002 & 17,850 & 12,261 & 5,589 & 25,153 & 18,354 & 6,799 & 12,388 \\
\hline 2003 & 18,506 & 12,526 & 5,980 & 27,565 & 19,971 & 7,594 & 13,574 \\
\hline 2004 & 19,459 & 13,902 & 5,557 & 29,527 & 21,213 & 8,314 & 13,871 \\
\hline 2005 & 22,533 & 14,421 & 8,112 & 32,794 & 22,582 & 10,212 & 18,324 \\
\hline 2006 & 23,802 & 14,870 & 8,932 & 37,853 & 23,921 & 13,932 & 22,864 \\
\hline 2007 & 24,978 & 15,334 & 9,644 & 42,663 & 25,694 & 16,969 & 26,613 \\
\hline 2008 & 26,232 & 15,904 & 10,328 & 45,375 & 25,973 & 19,402 & 29,730 \\
\hline 2009 & 22,940 & 14,021 & 8,919 & 43,463 & 23,691 & 19,772 & 28,691 \\
\hline 2010 & 24,614 & 13,966 & 10,648 & 53,126 & 27,351 & 25,775 & 36,423 \\
\hline 2011 & 26,436 & 14,663 & 11,773 & 58,319 & 30,518 & 27,801 & 39,574 \\
\hline 2012 & 28,190 & 15,444 & 12,746 & 61,943 & 31,138 & 30,805 & 43,551 \\
\hline 2013 & 29,865 & 17,256 & 12,609 & 62,850 & 30,779 & 32,071 & 44,680 \\
\hline 2014 & 30,149 & 19,891 & 10,258 & 60,978 & 30,121 & 30,857 & 41,115 \\
\hline 2015 & 31,445 & 22,875 & 8,570 & 54,699 & 29,289 & 25,410 & 33,980 \\
\hline 2016 & 31,657 & 24,097 & 7,560 & 54,360 & 30,588 & 23,772 & 31,332 \\
\hline 2017 & 32,874 & 25,492 & 7,382 & 58,446 & 33,025 & 25,421 & 32,803 \\
\hline
\end{tabular}

Data source: United States Census Bureau, U.s. International Trade in Goods and Services.

One additional factor in the transformation of the region was crosscountry investment among NAFTA countries (Table 5). Flows were 
larger to the United States than to Mexico or Canada. The increase investment between Canada and the United States in 2017 can be explained by Precision Drilling, which is projected to become one of the largest providers of oil drilling services in the world, with a thriving business across Canada, the United States, and Mexico. This project is by far the most important investment project in the region, and it is expected to alter the energy outlook of the region.

Table 5. Intra-regional investment, 1994 and 2017 (millions of dollars)

\begin{tabular}{|l|c|c|c|c|c|}
\hline \multicolumn{5}{|c|}{1994} \\
\hline Canada & Canada & United States & Mexico & $\begin{array}{c}\text { Intra } \\
\text { NAFTA }\end{array}$ & $\%$ \\
\hline United States & $4,584.0$ & 0 & $1,058.0$ & $5,642.0$ & 49.3 \\
\hline Mexico & 739.2 & $4,951.1$ & 0 & $5,690.3$ & 49.8 \\
\hline Intra NAFTA & $5,323.2$ & $5,053.7$ & $1,058.0$ & $11,435.1$ & 100.0 \\
\hline & & 2017 & & & \\
\hline & Canada & United States & Mexico & Intra & $\%$ \\
\hline Canada & 0 & $18,014.0$ & 163.3 & $18,177.3$ & 41.3 \\
\hline United States & $18,624.0$ & 0 & $6,334.0$ & $24,958.0$ & 56.7 \\
\hline Mexico & 157.1 & 702.0 & 0 & 859.1 & 2.0 \\
\hline Intra NAFTA & $18,781.1$ & $18,716.0$ & $6,497.3$ & $43,994.4$ & 100.0 \\
\hline
\end{tabular}

Data sources: Global Affairs Canada (2018); B EA (n.d.).

\section{Bilateral bargaining and preliminary agreements}

In August 2018, Mexico and United States announced that a bilateral agreement had been reached; Canadians were still in the bargaining process, expecting that a trilateral agreement could be signed by the end of the year. The Mexican government did not publish details of the agreement, but the us Trade Representative published the following information (UST R 2018a, 2018b, 2018c): 
- The us initially proposed reducing the us merchandise trade deficit with its NAFTA partners and strengthening the rules of origin for the auto industry, raising the requirement from 62.5 percent to 80 percent regional content and 50 percent us content. After negotiations, Mexico and the United States agreed to set a goal of 75 percent regional content and to create a new labor value content rule. This deal uses trade rules to drive higher wages by requiring 40-45 percent of auto content be made by workers earning at least us $\$ 16$ per hour.

- Inclusion in the agreement of a chapter on Small and Mediumsized Enterprises (SMES) recognizes the contribution that SMES make to the region's economies. The chapter will support the development of SMEs by enhancing their ability to participate in and benefit from the opportunities created by the agreement, including through cooperative activities, information sharing, and the establishment of a NAFTA Trilateral sme Dialogue, involving the private sector, nongovernment organizations, and other stakeholders.

- New provisions on textiles are intended to promote us and Mexican production of textiles and apparel, strengthen customs enforcement, and facilitate broader consultation and cooperation on related issues. The new provisions are stronger with respect to both enforcement and production incentives.

- A controversial issue during bargaining was the agreement's antidumping and countervailing-duty provisions; the United States wanted to eliminate them, but Canada and Mexico were firmly committed to them.

- The United States and Mexico agreed to support innovations in biotechnology and agriculture and to reduce the use of tradedistorting policies. To facilitate the marketing of food and agricultural products, they agreed that grading standards and services will be nondiscriminatory, including for grains, and that grading will operate independently from domestic registration systems 
for grains and oilseeds. They also agreed to provisions regulating cheese ingredients.

- For the first time in NAFTA, the United States and Mexico agreed to geographical indication ${ }^{1}$ (GI) standards that enhance transparency for opposition and cancellation proceedings, establish a mechanism to consult on Gis pursuant to international agreements, and allow for consideration of additional factors in determining whether a term for a product is a common name instead of a GI. For the first time in a Us trade agreement, Mexico and the United States agreed not to restrict market access in Mexico for us cheeses labeled with certain names.

- The two countries agreed to labeling and certification provisions that will facilitate trade in wine and distilled spirits. Mexico agreed to continue recognizing "bourbon whiskey" and "Tennessee whiskey" as distinctive us products, and the United States agreed to do the same for "tequila" and "mezcal."

- They agreed on a new Annex on Proprietary Food Formulas, which requires them to protect the confidentiality of these formulas equally for domestic and imported products. The annex also limits such information requirements to what is necessary to achieve legitimate objectives.

- They also agreed to strengthen NA FTA's protections for intellectual property rights, which are critical to driving innovation and creating economic growth.

- A new chapter on digital trade prohibits customs duties and other discriminatory measures from being applied to digital products (such as e-books, videos, music, software, and games) that are distributed electronically. This will ensure that data can be transferred cross-border, and that limits on where data can be stored and processed are minimized, thereby enhancing and protecting the global digital ecosystem. The agreement will ensure that

1 A geographical indication (GI) is a sign used on products that have a specific geographicalorigin and possess qualities or a reputation that are due to that origin. In order to function as a GI, a sign must indetify a product as originating in a given place. 
suppliers are not restricted in their use of electronic authentication or electronic signatures, thereby facilitating digital transactions, and will guarantee that enforceable consumer protections, including regarding privacy and unsolicited communications, apply to the digital marketplace. It will limit governments' ability to require disclosure of proprietary computer source code and algorithms, to better protect the competitiveness of digital suppliers. It will promote collaboration in tackling cybersecurity challenges while seeking to promote industry best practices to keep networks and services secure; and it will promote open access to government-generated public data, to enhance innovative use in commercial applications and services.

- The updated financial services chapter includes commitments to liberalize financial services markets and facilitate a level playing field for financial institutions and cross-border trade in financial services.

- The labor chapter includes an Annex on Worker Representation in Collective Bargaining in Mexico, under which Mexico commits to specific legislative actions to recognize the right to collective bargaining. This chapter requires the parties to adopt and maintain in law and practice labor rights as recognized by the International Labor Organization, to effectively enforce their labor laws, and not to waive or derogate those laws.

- The environment chapter includes a comprehensive set of enforceable environmental obligations that were not stated in any previous United States agreement, including obligations to combat trafficking in wildlife, timber, and fish; to strengthen the relevant law enforcement networks; and to address pressing environmental issues such as air quality and marine litter.

Thus far, the United States has approached NAFTA renegotiations on a bilateral basis. As this book goes to press, all three countries could sign NAFTA agreement in the next weeks. But it has become clear that the United States has changed its focus from multilateral to bilateral 
mechanisms, at the same time imposing additional trade restrictions on other trading partners (such as China and Europe). Multilateralism has been damaged, and Mexico has accepted the new rules of the game.

\section{NAFTA's unequal results}

Mexican political forces are divided about NAFTA. Government and business organizations largely agree that it has fostered exports and helped to develop global value chains, which increased the value of exports and modified the pattern of imports; they support the idea that NAFTA modernization could promote further improvements. The most dynamic traded industries between Mexico and The United States are shown in the Table 6, wich ranks by its import and export values.

Table 6. Mexico: foreign trade with the United States by industry, 2017 (millions of dollars)

\begin{tabular}{|c|l|c|c|l|c|}
\hline Rank & \multicolumn{2}{|c|}{ Imports } & Rank & \multicolumn{2}{c|}{ Exports } \\
\hline 1 & $\begin{array}{l}\text { Industrial supplies and } \\
\text { materials }\end{array}$ & 88,582 & 1 & $\begin{array}{l}\text { Automotive vehicles, } \\
\text { parts, and engines }\end{array}$ & 116,467 \\
\hline 2 & $\begin{array}{l}\text { Capital goods except } \\
\text { automotive }\end{array}$ & 81,986 & 2 & $\begin{array}{l}\text { Capital goods except } \\
\text { automotive }\end{array}$ & 93,425 \\
\hline 3 & $\begin{array}{l}\text { Automotive vehicles, } \\
\text { parts, and engines }\end{array}$ & 33,877 & 3 & $\begin{array}{l}\text { Consumer goods } \\
\text { except food and } \\
\text { automotive }\end{array}$ & 38,176 \\
\hline 4 & $\begin{array}{l}\text { Travel (for all purposes } \\
\text { including education) }\end{array}$ & 17,932 & 4 & $\begin{array}{l}\text { Industrial supplies and } \\
\text { materials }\end{array}$ & 33,434 \\
\hline 5 & $\begin{array}{l}\text { Foods, feeds, and } \\
\text { beverages }\end{array}$ & 17,208 & 5 & $\begin{array}{l}\text { Foods, feeds, and } \\
\text { beverages }\end{array}$ & 26,894 \\
\hline 6 & $\begin{array}{l}\text { Consumer goods } \\
\text { except food and } \\
\text { automotive }\end{array}$ & 14,360 & 6 & $\begin{array}{l}\text { Travel (for all purposes } \\
\text { including education) }\end{array}$ & 17,077 \\
\hline 7 & $\begin{array}{l}\text { Other general } \\
\text { merchandise }\end{array}$ & 7,738 & 7 & $\begin{array}{l}\text { Other general } \\
\text { merchandise }\end{array}$ & 8,334 \\
\hline
\end{tabular}

Data source: Bureau of Economic Analysis. 
Although NAFTA has increased trade, it has not brought about the expected growth in the Mexican economy. Other countries that had similar conditions in the 1990s have seen their economies begin to catch up with United States. Korea and Malaysia were paired with Mexico in the 1990s in terms of GDP PP P; now they are dynamic economies that have surpassed the Mexican economy; China, which was lagging behind, has now almost caught up with Mexico (Figure 1). NA FTA has helped Mexico to develop an export platform, but has not fueled any strategic change to foster growth, it would have been necessary to have higher investment coefficients, as has been the case of Asian economies. Mexico investment coefficient in 2017 was of 23, while the coefficient in China was 44, Korea 31 and Malaysia 26. Catch-up process would have required that Mexico and partners would have structured a more ambitious project with larger investments to revamp the regional project; it demands a new strategy where investment and innovation will be the key factors to foster regional growth.

Figure 1. GDP per cápita in PPP of NAFTA members and selected other countries, 1990-2017

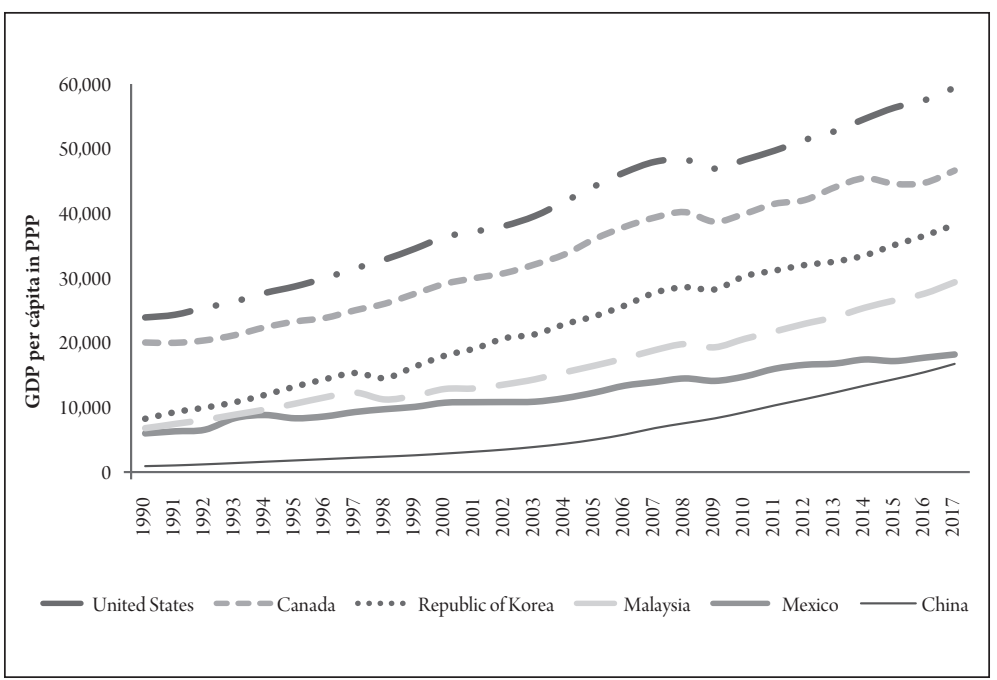

Data source: World Bank, World Development Indicators. 
In NAFTA, Mexico and Canada entered a deal with a mammoth economy; their entire national economies are the size of a small handful of Us states (Figure 2). The bargaining process should have taken this size difference into consideration and introduced safeguards to guarantee the rapid growth of the Mexican economy.

Figure 2. Mexican and Canadian GDP compared to the GDP of two US states and the District of Columbia (2017)

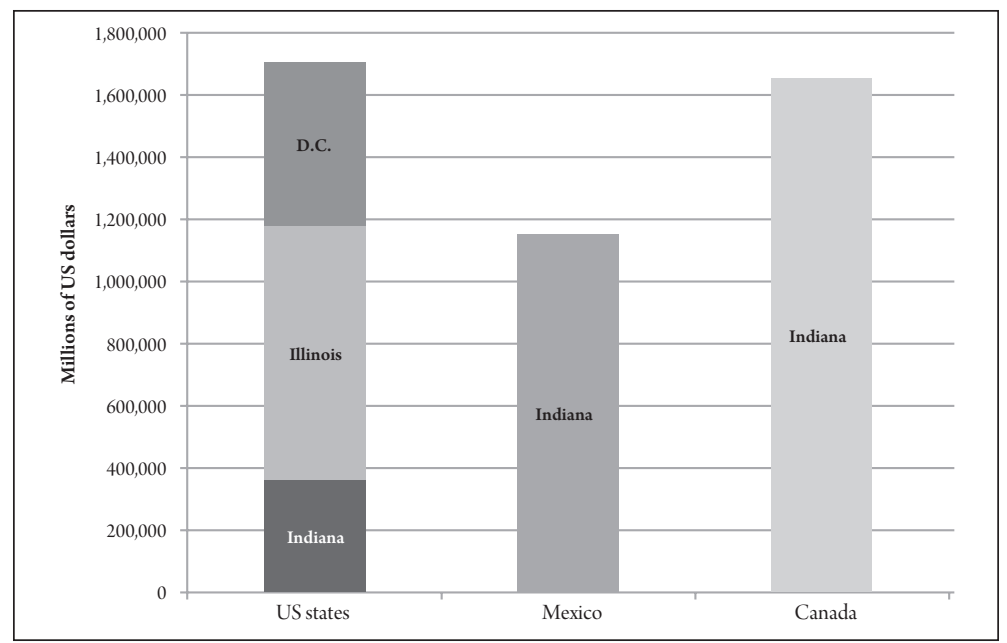

Data sources: United States: BEA, GD P by state. Data Available on: https://www.bea.gov/ data/gdp/gdp-state; Mexico and Canada: GDP (current Us\$). Data available on: https:// data.worldbank.org/indicator/NY.GDP.MKTP.CD

However, NAFTA has helped to prepare the Mexican economy for globalization, and its disruption would have negative effects on capital accumulation and on day-to-day economic operations, bringing distress to the United States and Canada as well, as 4.9 million jobs in the United States are directly linked to exports to Mexico. 


\section{A final word}

NAFTA renegotiations presented an opportunity to revitalize the North American region through an increase in its competitiveness, but that would have been made possible only by the creation of a common market, rather than a free trade agreement, under which the United States has become a winner and Canada and Mexico have not been able to change the agenda and could only bargain to avoid larger losses. The quest for a more comprehensive agreement will remain on the agenda for Mexico and Canada.

\section{References}

Banxico. Balanza de Pagos. Banco de México. Sistema de Información Económica, 2017.http://www.banxico.org.mx/SieInternet/

Baughman, Laura M., and Joseph F. Francois. 2010. Opening Markets, Creating Jobs: Estimated u.s. Employment Effects of Trade with fta Partners. United States Chamber of Commerce.

B E A (Bureau of Economic Analysis, us Department of Commerce) u.s. Direct Investment Abroad: Financial Transactions Without Current-Cost Adjustment, 2017. www.bea.gov/international/dil usdbal.

Blecker, Robert A., and Gerardo Esquivel. 2011. "Trade and the Development Gap." In Mexico and the United States: The Politics of Partnership, edited by Peter H. Smith and Andrew Selee, 83-110. Boulder, co: Lynne Rienner.

Global Affairs Canada. 2018. Foreign Direct Investment Statistics-Outward and Inward. www.international.gc.ca/economist-economiste/statistics-statistiques/outward_inward-actifs_passifaspx?lang=eng McKinsey \& Company. 2014. A Tale of Two Mexicos: Growth and Prosperity in a Two-Speed Economy. United States: McKinsey Global Institute. 
McKinsey \& Company. n.d. "Technical Appendix." In Making it in America: Revitalizing us Manufacturing. United States: McKinsey Global Institute.

Perrin, B., and A. Rozental. 2012. Forging a New Strategic Partnership between Canada and Mexico. Waterloo, Canada: The Centre for International Governance Innovation; Ottawa, Canada: Canadian Chamber of Commerce.

Prebisch, Raul. 1986. Terms of Trade Raul Prebisch and the Challenges of the XXI Century. CEPAL Review No.28, pp. 203-214, Santiago de Chile: CEPAL.

Ruiz, C. 2015. "Reestructuración Productiva e Integración. TLCAN 20 años después." Revista Problemas del Desarrollo 180 (46): 27-50.

Secretaría de Economía. 2017. Informe a la Cámara de Senadores del $H$. Congreso de la Unión sobre el inicio de negociaciones para la modernización del Tratado de Libre Comercio de América del Norte (tlcan) entre Canadá, Estados Unidos y México. México: Senado de la República. U s T R (Office of the us Trade Representative).2017. Summary of Objectives for the NAFTA Renegotiation. Washington, DC: USTR.

Ustr (Office of the us Trade Representative). 2018a. United StatesMexico Trade Fact Sheet: Modernizing NAFTA into a 21st Century Trade Agreement. Washington, DC: USTR. https://ustr.gov/aboutus/policy-offices/press-office/fact-sheets/2018/august/unitedstates\%E2\%80\%93mexico-trade-fact-sheet-1.

Us TR (Office of the us Trade Representative). 2018b. United StatesMexico Trade Fact Sheet: Rebalancing Trade to Support Manufacturing. Washington, DC: USTR. https://ustr.gov/about-us/ policy-offices/press-office/fact-sheets/2018/august/unitedstates\%E2\%80\%93mexico-trade-fact-sheet.

Ustr (Office of the us Trade Representative). 2018c. United StatesMexico Trade Fact Sheet: Strengthening North American Trade in Agriculture. Washington, DC: USTR. https://ustr.gov/about-us/ policy-offices/press-office/fact-sheets/2018/august/unitedstates\%E2\%80\%93mexico-trade-fact-sheet-0. 
Villareal, Maria Angeles, and Ian Fergusson. 2017. NAFta Renegotiation and Modernization. Washington, DC: Congressional Research Service.

World Bank. 2017. Global Value Chain Development Report 2017: Measuring and Analyzing the Impact of gvcs on Economic Development. Washington, DC: International Bank for Reconstruction and Development.

w T O (World Trade Organization). 2017. World Trade Statistical Review 2017. Geneva: WTO.

w To (World Trade Organization). 2018. Highlights of World Trade in 2017. Geneva: wTo. www.wto.org/english/res_e/statis_e/ wts2018_e/wts2018chapter02_e.pdf. 


\section{Possibilities for the Expansion of Intra-industry Trade between China and Mexico}

Jorge Eduardo Mendoza Cota

\section{Trade between Mexico and the United States and China}

Mexico's trade with the United States has included a substantial share of intra-industry trade. This trade has been affected by the emergence of China as a trading partner in the North American region.Trade between Mexico and the United States was stimulated by the entry into force of the North American Free Trade Agreement (N A FTA); by 2001, the United States was Mexico's main trading partner. However, the predominant commercial position of the us economy in Mexico has been declining

Table 1. Mexico-China trade, 2000-2016 (us\$)

\begin{tabular}{|l|r|r|r|}
\hline \multicolumn{1}{|c|}{} & Exports & \multicolumn{1}{c|}{ Imports } & \multicolumn{1}{c|}{ Balance } \\
\hline 2000 & $310,157,697$ & $2,877,853,587$ & $-2,567,695,890$ \\
\hline 2005 & $1,135,550,504$ & $17,696,345,195$ & $-16,560,794,691$ \\
\hline 2010 & $4,195,900,072$ & $47,787,866,690$ & $-43,591,966,618$ \\
\hline 2016 & $5,411,313,446$ & $69,520,668,449$ & $-64,109,355,003$ \\
\hline $\begin{array}{l}\text { Average annual } \\
\text { growth rate }\end{array}$ & $17.9 \%$ & $19.9 \%$ & $20.1 \%$ \\
\hline
\end{tabular}

Data source: Harmonized Commodity Description and Coding Systems classification in COMTRADE. 
in recent years, while the importance of the Chinese economy in North America, and in Mexico in particular, has increased markedly. Between 2000 and 2016, Mexican imports from China increased at an average annual rate of 19.9 percent, and Mexican exports to China at a rate of 17.9 percent (see Table 1). The Mexican economy quickly consolidated its commercial ties with China, generating new trade opportunities and challenges and commercial competition in North America.

Although Mexican exports to China are still relatively small, they have great potential for growth. Mexican exports are based partly on natural resources in which it has a comparative advantage and partly on global value chains and intra-industry trade. In 2000-2016, exports of mineral products increased rapidly. After mineral products, Mexican exports in the automotive sector had the second highest value; these, considered together with Mexico's imports of electrical goods from China, also reflect manufacturing trade between the two economies.

China's exports to Mexico have increased even more rapidly, making China the second largest exporter to Mexico and generating important changes in the North American region's trade. Chinese exports are

Table 2. Key elements of Mexico's trade with China, 2016

\begin{tabular}{|l|r|r|l|l|r|}
\hline \multicolumn{3}{|c|}{ Exports to China } & \multicolumn{3}{c|}{ Imports from China } \\
\hline \multicolumn{1}{|c|}{ Goods } & Value (US\$) & Percentage & \multicolumn{1}{c|}{ Goods } & Value (US\$) & Percentage \\
\hline $\begin{array}{l}\text { Metalliferous } \\
\text { minerals, slag, and ash }\end{array}$ & $1,423,683,004$ & $26.31 \%$ & $\begin{array}{l}\text { Electrical and } \\
\text { telecommunications } \\
\text { equipment }\end{array}$ & $29,145,554,326$ & $41.92 \%$ \\
\hline $\begin{array}{l}\text { Automobiles and } \\
\text { auto parts }\end{array}$ & $1,173,751,456$ & $21.69 \%$ & $\begin{array}{l}\text { Nuclear reactors and } \\
\text { boilers }\end{array}$ & $15,957,992,483$ & $22.95 \%$ \\
\hline $\begin{array}{l}\text { Electrical and } \\
\text { telecommunications } \\
\text { equipment }\end{array}$ & $761,333,369$ & $14.07 \%$ & $\begin{array}{l}\text { Optical and medical } \\
\text { equipment }\end{array}$ & $3,248,483,477$ & $4.67 \%$ \\
\hline $\begin{array}{l}\text { Nuclear reactors and } \\
\text { boilers }\end{array}$ & $460,566,088$ & $8.51 \%$ & Vehicles & $2,215,559,210$ & $3.19 \%$ \\
\hline Copper & $434,352,383$ & $8.03 \%$ & Plastics & $1,794,724,687$ & $2.58 \%$ \\
\hline
\end{tabular}

Data source: Harmonized Commodity Description and Coding Systems classification in COMTRADE. 
dominated by manufactured goods such as electrical and telecommunications equipment and components, optical equipment, plastics, and auto parts (see Table 2).

Trade between Mexico and China has thus grown dramatically and is based on Mexico's comparative advantage in terms of natural resources that are required by China for its economic growth. There is also a growing intra-industry trade in manufactures related to global value chains. This type of trade significantly links both economies and has also had an impact on trade between NA FTA members, as Chinese imports to Mexico are increasingly incorporated in Mexican exports to the United States.

\section{Mexico's intra-industry trade with North America and with China}

The integration of Mexican trade into the dynamics of the us economy has been impacted by the growing participation of China's economy in North American trade. The characteristics of trade and vertical foreign investment have determined that a large part of world trade is intra-industry; internationally, there are production chains to reduce costs in the most competitive global markets (León Pacheco González and Dussel Peters 2001). The entry into force of NAFTA intensified Mexico-Us trade related to supply chains in the automotive, electrical, and machinery industries. In Mexican manufacturing, this new trade dynamic led to the establishment of assembly plants that add value to intermediate goods and re-export them to the United States.

About 45 percent of Mexican trade with the United States is intraindustry. Likewise, manufacturing activities that expanded rapidly under NAFTA include manufacture of engines, auto parts, and motor vehicles, which have shown a slight deceleration in their participation in intraindustry trade.

Trade between Mexico and China is primarily inter-industry trade; only 17.4 percent can be considered intra-industry (Mendoza Cota 
2016). Some sectors have increased their intra-industry trade, including auto parts, machinery and engines, and textiles. Some incipient intraindustry trade also occurs in mining (see Table 3 ). These changes suggest that there may be opportunities for Mexico to further expand its exports in that category, particularly in new subsectors such as the food industry, film products, and some mining industries.

Table 3. Growth of the China-Mexico intra-industry trade index, 2005-2016

\begin{tabular}{|c|l|c|c|}
\hline Code & \multicolumn{1}{|c|}{ Products } & 2010 & 2016 \\
\hline 2 & Meats & -- & 0.89 \\
\hline 5 & $\begin{array}{l}\text { Products of } \\
\text { animal origin }\end{array}$ & -- & 0.78 \\
\hline 13 & Vegetables & 0.72 & 0.90 \\
\hline 23 & Food industry & & \\
\hline 25 & Salt and sulfides & & 0.75 \\
\hline 0.11 & 0.78 & 0.01 & 0.38 \\
\hline 27 & Mineral fuels & 0.27 & 0.85 \\
\hline 36 & Explosives & 0.12 & 0.60 \\
\hline 37 & Film products & 0.73 & 0.69 \\
\hline 79 & Zinc & 0.27 & 0.04 \\
\hline 87 & Vehicles & 0.74 & 0.20 \\
\hline 29 & Organic chemicals & 0.69 & \\
\hline 72 & Iron and steel & & -12 \\
\hline
\end{tabular}

Data source: Harmonized Commodity Description and Coding Systems classification in COMTRADE.

\section{Value-added trade and NAFTA}

According to the us Department of Commerce, the added value generated by the value chains in the manufacturing sector in North America has contracted in the last seven years. Countries in the NAFTA region are the main suppliers of value added in the manufacturing sector for the United States, followed by China (see Table 4). 
Table 4. Value added in imports of us manufactured goods

\begin{tabular}{|c|r|r|r|r|r|r|}
\hline NAFTA & \multicolumn{1}{|c|}{1995} & \multicolumn{1}{|c|}{1998} & $\mathbf{2 0 0 0}$ & \multicolumn{1}{c|}{$\mathbf{2 0 0 4}$} & \multicolumn{1}{c|}{$\mathbf{2 0 0 8}$} & \multicolumn{1}{c|}{$\mathbf{2 0 1 1}$} \\
\hline $\begin{array}{l}\text { United } \\
\text { States }\end{array}$ & 8.7 & 10.3 & 10.2 & 7.8 & 6.6 & 6.4 \\
\hline Canada & 13.2 & 12.2 & 12.1 & 11.7 & 9.3 & 8.8 \\
\hline Mexico & 5 & 6.4 & 6.7 & 6 & 6 & 6.8 \\
\hline Non-NAFTA & 73.1 & 71.1 & 71 & 74.4 & 78.2 & 77.9 \\
\hline $\begin{array}{c}\text { Southeast } \\
\text { Asia }\end{array}$ & 37.1 & 32.6 & 32.4 & 31.6 & 33.2 & 34.7 \\
\hline China & 2.8 & 4.2 & 4.2 & 7.8 & 13.7 & 15.5 \\
\hline
\end{tabular}

Source: Flatness and Rasmussen (2017).

The share of Canada and Mexico in the value added of $U$ s manufacturing imports fell from 27 percent in 1995 to 22 percent in 2011, and China's contribution increased from 2.8 percent to 15.5 percent (Flatness and Rasmussen 2017). In particular, imports of Us automobile engines from the NAFTA region declined, from 87 percent in 1995 to 71 percent in 2011, while the value of automobile engines imported from non-NAFTA economies increased from 13 percent to 29 percent. From this perspective, it appears that the penetration of the Chinese and other Asian economies into trade in the North American region has generated a significant change in that region. As a result, the us government is rethinking trade with China and other Asian economies, both by the United States and by its NA FTA partners.

\section{China-Mexico trade perspectives under NAFTA}

To the extent that the Mexican and Us economies are integrated, changes in NAFTA would impact the value chains of trade between Mexico and the United States and with China. These chains could be affected in their distribution and production and assembly mechanisms, particularly in the automotive and electronic sectors. 
Cancellation of NAFTA would impact regional economic relations by increasing the costs of trade. Vehicle tariffs are 10.5 percent in Mexico and 3.1 percent in the United States. Engines for transport vehicles have a tariff of 18.4 percent in Mexico and 19.9 percent in the United States. Mexico has a high average tariff of 31.3 percent for passenger vehicle engines, while that of the United States is 2.5 percent (w T O 2018).

The intra-industry trade, which reflects the exchange of added value, could be affected in certain manufacturing sectors where companies consider that the cost of higher tariffs is not compensated by cost savings for inputs and transport. A revised NA FTA could seek greater integration of value chains within North America, placing constraints on ChinaMexico trade. This would create challenges for Mexican commercial policy, particularly for its objectives of expanding international markets and nurturing economic relations with China.

\section{Recommendations}

Fragmentation and specialization of production are increasing in the North American region. Mexico's trade policy will have to adapt to the results of the NAFTA renegotiation. A new NAFTA, both in the direction of a probable greater commercial integration with North America or towards diversification, will require changes in the instruments and goals of Mexico's trade policy. With regard to trade with China, the Mexican government will have to be firm in continuing to diversify by generating strategic trade policies. These policies should be related to the refinement of studies and support instruments for commercial sectors integrated into global value chains, especially agri-food activities and the electronic, computer, and auto parts industries.

Mexico's competitive advantages within North America include its endowment of natural resources and its proximity to the us market. The determinants of foreign direct investment are related to pricing decisions that are based on economies of scale and transportation costs. Therefore, Mexico's most competitive exports are likely to be those that have 
a greater proportion of weight to value (Watkins 2013) and/or that rely on its most abundant natural resources -as is the case in the automotive assembly industry.

In trade with China, Mexico would also have the possibility of expanding exports in the mining and food industries, where it has comparative advantages based on its natural resource endowments. In addition, industries linked to global value chains -such as the electrical, electronic, and automobile manufacturing industries-could reinforce the existing commercial articulation.

\section{References}

Flatness, Anne, and Chris Rasmussen. 2017. U.s.-Produced Value in U.S. Imports from NAFTA. Washington, DC: Office of Trade and Economic Analysis, Industry and Analysis, International Trade Administration, Department of Commerce.

León Pacheco González, Alejandra, and Enrique Dussel Peters. 2001. "El comercio intraindustrial en México 1990-1999." Comercio Exterior 51(7): 652-664.

Mendoza, Jorge Eduardo. 2016. "Revealed Comparative Advantages and Intra-industry Trade Changes between Mexico, China and the Us A." PORTe S, Revista mexicana de estudios sobre la Cuenca del Pacífico 10(20): 9-41.

Ortiz Velásquez, Samuel, and Enrique Dussel Peters. 2016. "La nueva relación comercial entre América Latina y el Caribe-China: ¿Integración o desintegración regional?” In La nueva relación comercial entre América Latina y el Caribe-China: ¿Integración o desintegración regional?, edited by Enrique Dussel Peters, 13-58. Mexico City: Center for China-Mexico Studies, School of Economics, National Autonomous University of Mexico, and UD UAL. 
Watkins, Ralph. 2013. "Meeting the China Challenge to Manufacturing in Mexico." In China and the New Triangular Relationships in the Americas: China and the Future of us-Mexico Relations, edited by Enrique Dussel Peters, Adrian H. Hearn, and Harley Shaiken, 37-58. Miami: Center for Latin American Studies, University of Miami; Berkeley: Center for Latin American Studies, University of California, Berkeley; Mexico City: Center for China-Mexico Studies, School of Economics, National Autonomous University of Mexico.

w To (World Trade Organization). 2018. TariffDownload Facility: Database on Tariffs Imposed by Member Countries under the Concept of Most Favored Nation, According to the Harmonized System (HS). Geneva: w TO. 


\section{Mexico's Trade Relations with NAFTA Partners and with China from the Perspective of the Mexican Footwear Industry}

Alejandro Gómez Tamez

This chapter analyzes the role that China has played in the integration of North America through the North American Free Trade Agreement (NAFTA), as well as the consequences that the possible cancellation of this agreement could have for the Mexican footwear industry. The chapter is divided into five sections. The first describes the evolution of trade between Mexico and the United States and between Mexico and China. The next sections analyze the causes of the low growth of Mexican exports to China and review how China spoiled the NAFTA party. An analysis of China's impact on the footwear trade under NAFTA follows, and finally, conclusions and recommendations are presented.

\section{Mexico's trade with the United States and China}

\section{Mexico and the United States}

The United States is undoubtedly Mexico's main commercial partner; it was the destination of 79.84 percent of Mexico's exports and the origin of 46.3 percent of Mexico's imports in 2017. Figure 1 shows export and import trends over the last two decades. 
Figure 1. Mexican exports to and imports from the United States, 1993-2017 (us \$ thousands)

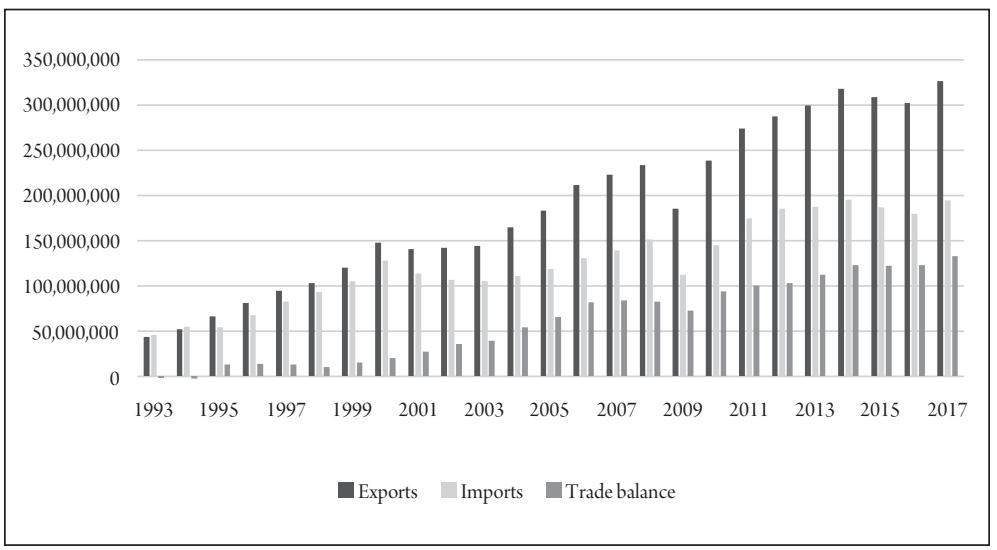

Data source: INEGI.

Mexican exports to and imports from the United States both fell substantially after China's entry into the World Trade Organization (w TO) in 2001 (Table 1).

Table 1. Mexico-us trade before and after 2001 (average annual growth).

\begin{tabular}{|l|c|c|} 
& Exports & Imports \\
\hline $1990-2001$ & $19.9 \%$ & $17.2 \%$ \\
\hline $2002-2017$ & $5.9 \%$ & $4.1 \%$ \\
\hline
\end{tabular}

Data source: INEGI.

In nominal terms, the average annual growth of Mexican exports to the United States during 2002-2017 was u S 11 .7 billion, while that of Mexican imports from the United States during the same period was Us \$5.0 billion. Figure 2 shows these trends as annual percentages.

Mexico went from having a trade deficit with the United States of U S $\$ 2.4$ billion in 1993 to surpluses of us $\$ 35.3$ billion in 2002 and us $\$ 132.4$ billion in 2017. 
Figure 2. Mexico-us trade, average annual growth, 1994-2017

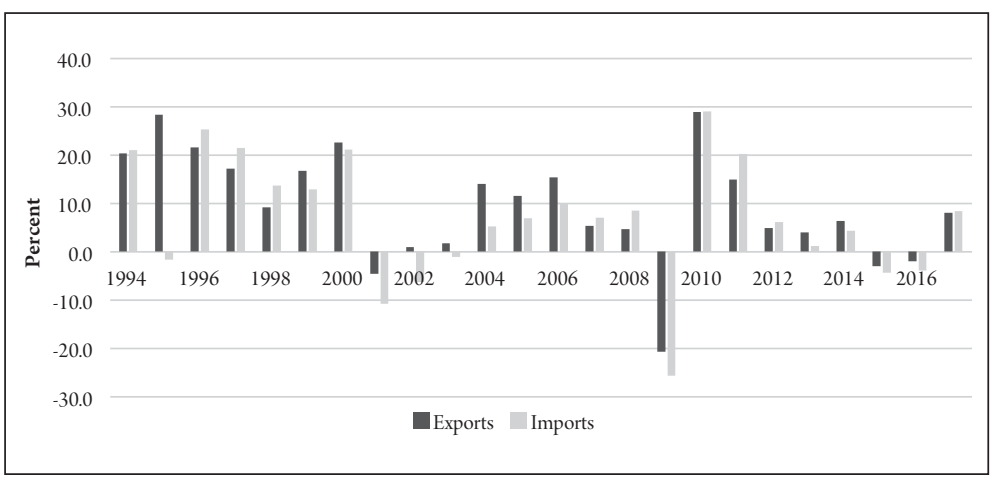

Data source: INEGI.

\section{Mexico and China}

Trade between Mexico and China has become increasingly unbalanced; in 2017, China was the destination of just 1.6 percent of Mexico's exports and the origin of 17.6 percent of its imports. This trend is shown in terms of annual totals in Figure 3.

Figure 3. Mexico-China trade, 1993-2017 (US\$ thousands)

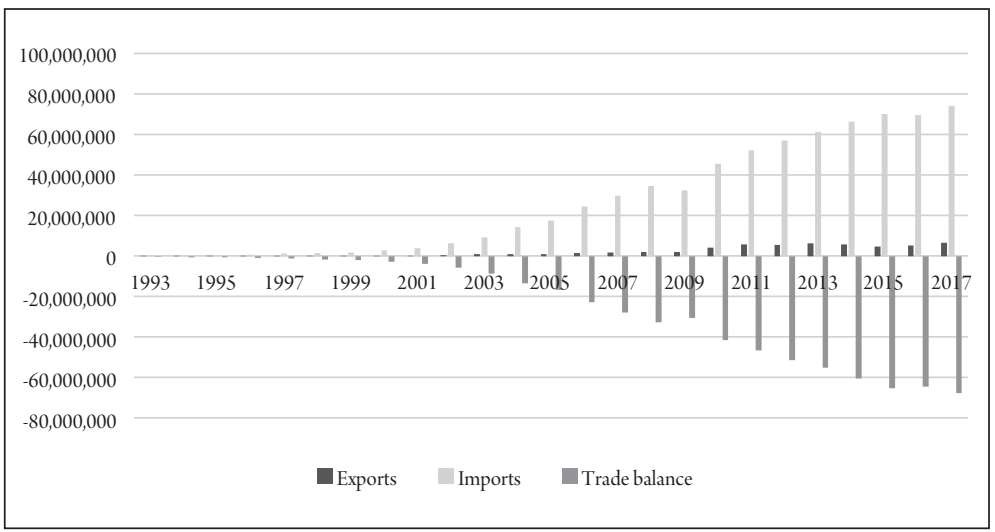

Data source: INEGI. 
The average annual growth rate of exports from Mexico to China increased after China joined the w T O the corresponding growth rate for imports to Mexico from China decreased in the same period (Table 2).

Table 2. Average annual growth in Mexico-China trade before and after 2001

\begin{tabular}{|l|c|c|}
\hline $1990-2001$ & Exports, Mexico to China & Imports, China to Mexico \\
\hline $2001-2016$ & $16.1 \%$ & $29.5 \%$ \\
\hline
\end{tabular}

Data source: INEGI.

In nominal terms, during 2002-2017, the average annual growth of Mexican exports to China was only us $\$ 401$ million, while that of Mexican imports from China was over U $\$ 4.4$ billion. These trends are shown in percentages in Figure 4.

Figure 4. Average annual growth in Mexico-China trade by year, 1994-2017

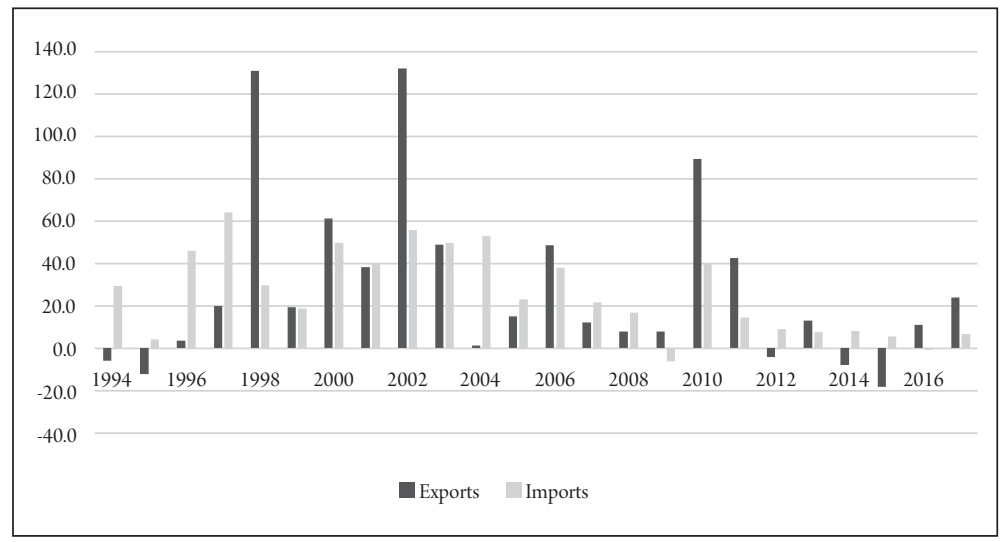

Data source: INEGI.

With China, Mexico went from a trade deficit of us \$341 million in 1993 to one of over u s \$5.6 billion in 2002 and over u s \$67.4 billion in 2017. As can be seen in Figure 3, this deficit is a chronic problem for Mexico. 
Mexico's trade deficit with China was the equivalent of 50.9 percent of its trade surplus with the United States in 2017, compared to 14.3 percent in 2001 (Figure 5).

Figure 5. Mexico's trade deficit with China as a percentage of its trade surplus with the United States, 1993-2017

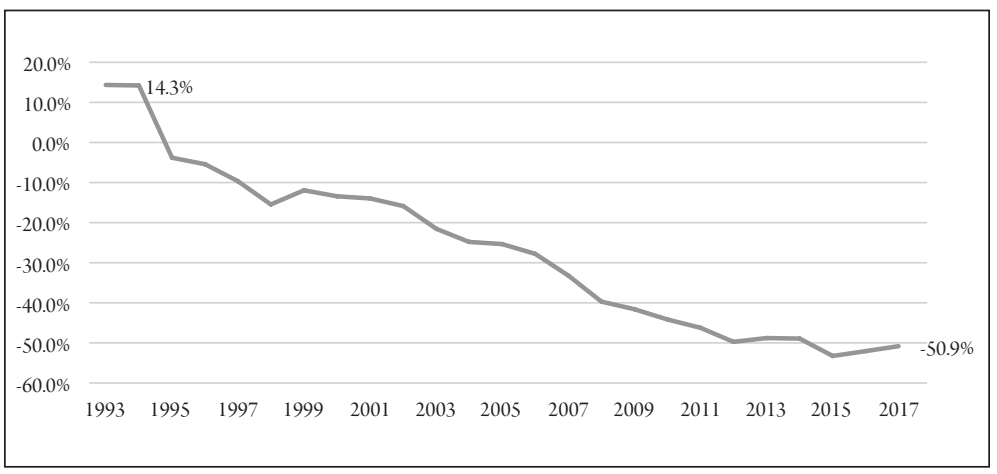

Data source: INEGI.

For many analysts, these data suggest that a large part of Mexico's trade deficit with China is due to the acquisition of inputs to be transformed into intermediate goods and final consumer goods that are eventually exported to the United States. That is, the trade surplus with the United States cannot be understood without reference to the trade deficit with China.

\section{Causes of the low growth of exports from Mexico to China}

Among the causes that explain the low penetration of Mexican exports in the Chinese market is the fact that the import cost in China is considerably higher than in Mexico. As can be seen in Table 3, the tariff rate applied, simple average, for products manufactured in China is substantially higher than that applied in Mexico. The cost for compliance with 
the documentation requirements is 70 percent higher for imports into China than for imports into Mexico (Lerin 2017).

Table 3. China's and Mexico's tariff rates, applied, simple average, for manufactured products, 2010-2015 (percentage of imports).

\begin{tabular}{|c|c|c|c|c|c|c|}
\hline & 2010 & 2011 & 2012 & 2013 & 2014 & 2015 \\
\hline \multicolumn{7}{|c|}{ Tariff rate, applied } \\
\hline China & 7.87 & 7.8 & & & 7.58 & 7.51 \\
\hline Mexico & 7.41 & 7.03 & 6.32 & 6.06 & 2.82 & \\
\hline \multicolumn{7}{|c|}{ Tariff rate, Most Favored Nation } \\
\hline China & 9.2 & 9.18 & & & 9.02 & 9.04 \\
\hline Mexico & 7.56 & 6.53 & 6.01 & 5.78 & 5.75 & \\
\hline
\end{tabular}

Data source: World Bank (n.d.).

Although China's official rhetoric calls for increased imports from Mexico, it has taken no concrete steps to facilitate this (Lerin 2017). Mexico and China have signed more than 100 bilateral documents; however, the subject matter has not been specified and no effect has been observed in practice.

\section{How China spoiled the NAFTA party}

China penetrated many new markets that had been opened through NAFTA (ECLAC), and Chinese products achieved a substantial market share in Mexico and the United States.

From 1994 to 2001, Mexico enjoyed a "honeymoon" with the United States; no other country had enjoyed the same proximity and tariff preferences. Despite this, the GD P gap between the two countries actually increased: in 1993, Mexico's per capita GDP was 20.95 percent of that of the United States, and in 2016 it was only 16.13 percent (Dussel Peters 2017). 
The honeymoon ended in 2001 when China joined the WTO and began to have similar access to the Us market. In 2009, 84 percent of Mexico's manufacturing exports to the United States were under threat from China (that is, they were in sectors in which Mexico was losing market share), while 96 percent of us exports to Mexico were also under threat from China.

NAFTA significantly increased the share of intra-regional trade, from below 38 percent in the early 1990s to 46.4 percent in 2000. Since then it has fallen again to close to 40 percent.

This recent and growing process of regional disintegration has become widespread, although with differences in specific value chains and considering at least two phases of NA FTA (Dussel Peters and Ortiz Velásquez 2016):

1. 1994-2000, with dynamic trade, investment, and employment generation

2. 2001 until today, during which the integration process has regressed, affecting the same variables.

The United States is by far Mexico's main trading partner, although its share has fallen from above 81 percent in 1999 to 63.37 percent in 2016. This process has coincided with a deepening of regional integration under NAFTA during 1994-2000 and its increasing disintegration since then. It has also coincided with the growing presence of China in Mexico and in the NAFTA region as a whole.

The share of Mexican exports that went to the United States fell from over 88 percent in 1999-2000 to just under 81 percent in 2016. The share of Mexican imports that came from the United States exceeded 75 percent during much of the 1990s; but since 2007, they have represented less than 50 percent, and only 46.40 percent in 2016.

Finally, Mexico's growing trade surplus with the United States is the result of the significant fall in the competitiveness of us exports and their displacement in the Mexican market by Asian competitors, particularly 
from China, which has been Mexico's second most active commercial partner since 2003 (Dussel Peters 2017).

\section{NAFTA and China: Impact on the footwear trade}

In the footwear trade (chapter 64 of the General Import and Export Tax Tariff or TigiE), as Tables 4 and 5 show, Mexico has developed a large and growing trade deficit with the United States.

Table 4. United States' trade balance with selected other countries in footwear, 1990-2016

\begin{tabular}{|l|r|r|r|r|r|r|r|r|r|}
\hline \multicolumn{9}{|c|}{ US\$, millions } & \multicolumn{2}{c|}{$\begin{array}{c}\text { Average annual } \\
\text { growth rate }\end{array}$} \\
\cline { 2 - 11 } & \multicolumn{1}{|c|}{1990} & 1994 & 1995 & 2000 & 2010 & 2015 & 2016 & $\begin{array}{c}\text { 1994- } \\
2000- \\
2016\end{array}$ \\
\hline (1) China & $-1,477$ & $-5,251$ & $-5,815$ & $-9,151$ & $-15,861$ & $-17,196$ & $-14,730$ & 9.7 & 3.0 \\
\hline (2) Vietnam & 0 & 0 & -2 & -97 & $-1,576$ & $-4,369$ & $-4,794$ & 239.4 & 27.6 \\
\hline (3) Indonesia & -241 & -878 & -944 & -717 & -57 & $-1,399$ & $-1,432$ & -3.3 & 4.4 \\
\hline (4) Italy & -959 & -871 & $-1,004$ & $-1,257$ & -890 & $-1,405$ & $-1,351$ & 6.3 & 0.5 \\
\hline (5) India & -59 & -97 & -92 & -108 & -174 & -465 & -501 & 1.8 & 10.0 \\
\hline (6) Mexico & -100 & -103 & -164 & -189 & -210 & -360 & -317 & 10.6 & 3.3 \\
\hline Total & $-9,013$ & $-10,958$ & $-11,315$ & $-13,987$ & $-19,802$ & $-26,202$ & $-24,268$ & 4.2 & 3.5 \\
\hline
\end{tabular}

Data source: Dussel Peters (2017).

China and Vietnam have become major trading partners of the United States. In 1990, taken together, they were the source of only 15.43 percent of U imports, while in 2016 they accounted for 57.81 percent and 19.16 percent, respectively. Mexico increased its share of Us footwear imports from 13.21 percent in 1990 to 21.02 percent in 2000, but this fell to 8.69 percent in 2016. 
Table 5. Footwear trade and tariff rates, United States and major trading partners, 1990-2016.

\begin{tabular}{|c|c|c|c|c|c|c|c|c|c|}
\hline & 1990 & 1994 & 1995 & 2000 & 2010 & 2015 & 2016 & $\begin{array}{l}1994- \\
2000\end{array}$ & $\begin{array}{l}2000- \\
2016\end{array}$ \\
\hline & \multicolumn{7}{|c|}{ Exports (US\$, millions) } & \multicolumn{2}{|c|}{$\begin{array}{c}\text { Average annual } \\
\text { growth }\end{array}$} \\
\hline Total & 563 & 758 & 791 & 867 & 1,104 & 1,458 & 1,366 & 2.3 & 2.9 \\
\hline (4) China & 1 & 8 & 9 & 44 & 58 & 81 & 90 & 33.2 & 4.6 \\
\hline (2) Vietnam & 0 & 0 & 1 & 27 & 47 & 104 & 116 & 311.1 & 9.4 \\
\hline (8) Indonesia & 0 & 6 & 14 & 14 & 7 & 27 & 30 & 14.2 & 4.9 \\
\hline (23) Italy & 25 & 19 & 17 & 7 & 7 & 10 & 7 & -14.8 & -0.2 \\
\hline (57) India & 2 & 4 & 5 & 4 & 4 & 3 & 2 & -1.8 & -5.4 \\
\hline \multirow[t]{2}{*}{ (3) Mexico } & 65 & 103 & 72 & 162 & 109 & 134 & 97 & 7.9 & -3.2 \\
\hline & \multicolumn{7}{|c|}{ Imports (US\$, millions) } & \multicolumn{2}{|c|}{$\begin{array}{l}\text { Average annual } \\
\text { growth }\end{array}$} \\
\hline Total & 9,576 & 11,716 & 12,106 & 14,854 & 20,906 & 27,660 & 25,634 & 4.0 & 3.5 \\
\hline (1) China & 1,477 & 5,259 & 5,824 & 9,195 & 15,919 & 17,277 & 14,820 & 9.8 & 3.0 \\
\hline (2) Vietnam & 0 & 0 & 3 & 125 & 1,623 & 4,473 & 4,911 & 248.8 & 25.8 \\
\hline (3) Indonesia & 241 & 884 & 958 & 731 & 586 & 1,425 & 1,462 & -3.1 & 4.4 \\
\hline (4) Italy & 984 & 891 & 1,022 & 1,264 & 898 & 1,415 & 1,359 & 6.0 & 0.5 \\
\hline (5) India & 62 & 102 & 97 & 112 & 178 & 468 & 503 & 1.7 & 9.8 \\
\hline \multirow[t]{2}{*}{ (6) Mexico } & 165 & 206 & 237 & 351 & 319 & 494 & 413 & 9.3 & 1.0 \\
\hline & \multicolumn{7}{|c|}{ Tariffs as a percentage of total imports } & \multicolumn{2}{|c|}{$\begin{array}{l}\text { Average annual } \\
\text { growth }\end{array}$} \\
\hline Total & 10.35 & 10.62 & 10.66 & 10.96 & 9.92 & 10.48 & 10.99 & 0.5 & 0.0 \\
\hline (1) China & 11.71 & 11.46 & 11.49 & 11.81 & 10.05 & 10.48 & 10.71 & 0.5 & -0.6 \\
\hline (2) Vietnam & - & 37.69 & 22.62 & 27.75 & 12.25 & 12.80 & 13.75 & -5.0 & -4.3 \\
\hline (3) Indonesia & 8.01 & 11.37 & 12.17 & 12.00 & 12.05 & 12.95 & 13.96 & 0.9 & 0.9 \\
\hline (4) Italy & 9.25 & 9.28 & 9.18 & 9.14 & 9.89 & 9.79 & 9.99 & -0.2 & 0.6 \\
\hline (5) India & 5.83 & 7.36 & 7.57 & 8.18 & 8.67 & 8.64 & 9.37 & 1.8 & 0.9 \\
\hline (6) Mexico & 12.53 & 5.52 & 5.68 & 2.66 & 0.10 & 0.33 & 0.16 & -11.5 & -16.0 \\
\hline
\end{tabular}

Data source: Dussel Peters (2017).

Regarding the us trade in footwear (chapter 64 of the TIGIE), Mexico's share of both imports to and exports from the United States has fallen. US imports of footwear from Mexico dropped from 2.36 percent in 2000 to 1.61 percent in 2016. During the same period, exports of footwear from the United States to Mexico showed a negative average annual growth rate ( -3.2 percent), while its imports to Mexico showed a positive dynamism (1.0 percent). 
The us trade deficit with Mexico is secondary and represents us $\$ 317$ million or 1.31 percent of the Us trade deficit in footwear with the world.

The footwear market has high and relatively unchanged tariffs; during 1990-2016, the tariff on all of its imports of footwear remained within the range of 10-11 percent. Mexico has paid a tariff of less than 1 percent since 2010, and only 0.16 percent in 2016.

According to Dussel Peters (2017), if NA F TA had been cancelled in 2016, all Us imports from Mexico would be taxed at 3.25 percent (29 times the 0.12 percent at which they were taxed in 2016), paying an additional US $\$ 9.5$ billion.

Footwear (chapter 64) is among the sectors that would be most affected by a cancellation of NAFTA, which would increase the tariff from 0.16 percent to 8.22 percent (more than 50 times). However, as discussed above, footwear exports make up a relatively small portion of Mexican footwear production and of Mexican exports in general.

Thus, the footwear market reflects a significant shift of the United States by Asian countries, particularly by China and Vietnam. There has been a collapse in the us share of Mexican imports in general of more than 50 percent in the 1990s and in imports of footwear from 37.5 percent in 2000 to 3.0 percent in 2016. In the same period, China and Vietnam's share increased from about 2 percent (combined) in the 1990s to about 4.5 percent and 7.5 percent, respectively, in 2000, and 42.1 percent and 28.6 percent in 2016.

Exports also play a minor role in the footwear market of Mexico and remained practically stagnant during 2000-2010. Since then they have experienced significant growth, although less so than imports. As a result, the footwear market in Mexico has been in deficit since 2002, particularly with China and Vietnam.

Finally, the United States absorbs more than 80 percent of Mexican exports; in some years before 2004 the share even exceeded 94 percent. 


\section{Conclusions and recommendations}

It is important that the three NAFTA members explicitly address the causes of the growing disintegration of N AF TA in commercial terms and in specific markets (Dussel Peters and Ortiz Velásquez 2016).

The renegotiation of NAFTA allows the realization of a major update and modernization of the agreement. The update should incorporate the conditions of other commercial agreements that have been reached since 1994 and address new issues such as digital commerce and new techniques for identifying the origin of goods - both of which require revisions to existing rules. Mexico must continue its commercial diversification. The participation of the United States in Mexico's trade fell significantly during 2000-2016. In spite of that, total Mexican exports as well as footwear still show a high concentration in the United States. Intra-N A F TA trade in footwear has decreased significantly since the agreement's implementation and particularly in the case of Mexican imports from the United States. An updated NAFTA should include incentives to strengthen regional markets, including for footwear.

Government authorities and business organizations must implement a program to enhance the Mexican footwear industry's competitiveness, a conversion fund for the footwear industry, specific activities to increase the industry's competitiveness with exporting countries such as China and Vietnam, and upgrades to manufacturing technology. Support from the Ministry of Finance and Public Credit is also important to reduce the multiple illicit activities in the industry. 


\section{References}

Dussel Peters, Enrique. 2017. La cadena del calzado de México ante la renegociación del Tratado de libre Comercio de América del Norte. Condiciones y propuestas. Mexico City: CICEG and U NA M / Centro de Estudios China-México.

Dussel Peters, Enrique, and Samuel Ortiz Velásquez. 2016. Efectos del т P P en la cadena de valor del calzado en México. La industria del calzado en Vietnam. Mexico City: CICEG and UnAm/Centro de Estudios China-México.

World Bank. n.d. "Tasa arancelaria, aplicada, promedio ponderado, productos manufacturados (\%)" [Tariff rate, applied, weighted mean, manufactured products (\%)]. https://datos.bancomundial.org/indicador/TM.TAX.MANF.WM.AR.ZS?end=2015\&name_desc $=f$ alse \&start $=1988 \&$ view=chart. 
Section II.

And China? 



\title{
The New Triangular Relationship between Mexico, the United States, and China: Challenges for NAFTA
}

\author{
Enrique Dussel Peters
}

In the lifetime of the North America Free Trade Agreement (NAFTA), tensions between the signatories have never been so high as they have been since 2017. Canada and Mexico were not particularly interested in updating or modernizing N A F TA, which first came into force in January 1994; the Mexican government was concerned that the United States could include new demands in sensitive sectors such as labor and energy. But under the us Trump administration, renegotiations started in August 2017 and ended a year later.

In parallel to this negotiation process, the Trump administration in 2018 not only continued questioning Mexico and reiterated its interest in building a wall between the two countries but also unilaterally imposed tariffs on steel and aluminum from Mexico as well as from other countries. While it is not clear if the contradictions between these measures (unilateral tariffs and trade negotiations) will be resolved -that is, if import duties on Mexican goods will be canceled- the Trump administration has consistently escalated a trade war with China. After several months of criticizing China's trade surplus with the United States and its subsidies and theft of intellectual property, singling out "Made in China 2025" and other programs, the Trump administration imposed tariffs on Chinese steel and aluminum imports in May 2018, $\$ 50$ billion on additional Chinese imports in July 2018, and an additional 
Us $\$ 200$ billion in September 2018. China, has, in all cases, responded in kind. ${ }^{1}$

Surprisingly, there has been almost no explicit discussion of these tensions from a "triangular" perspective recognizing that the Chinese economic presence is growing not only in the United States (for which China has since 2016 been the main trading partner) but in the entire NAFTA region. The implications, as analyzed below, are substantial in terms of the ongoing integration of China in the region, as well as in terms of policies.

This chapter discusses China's ongoing trade integration with the NAFTA region in general (which has so far not been sufficiently acknowledged) and with Mexico in particular, focusing on specific chapters of the Harmonized TariffSystem and specific value-added chains. The last section summarizes the main issues and presents some policy conclusions.

\section{China's trade presence in the NAFTA region}

Scholars have discussed the impact of China's increasing presence on trade integration in Latin America and the Caribbean, and in particular in the NAFTA region (Dussel Peters and Ortiz Velásquez 2016; Moreno Brid et al. 2018). During 2000-2015, intra-regional trade increased substantially during the 1990s, and fell again to levels similar to those in 1994, when NAFTA first entered into force. Intra-industry trade and the share of NAFTA members' trade with each other went from below 45 percent in 1994 to 56.2 percent in 2000 and to just under 50 percent in 2014 -reflecting this process, as well as global commodity chains such as auto parts/automobiles and electronics. As important as these quantitative changes are, an increasing share of NAFTA's capital-goods imports have originated in China, from 18.9 percent in 2001 to 34.9 percent in 2014 (Dussel Peters and Ortiz Velásquez 2016, 258).

1 For a full and detailed discussion of the NAFTA renegotiation process and the recent USChina relationship, see Dussel Peters (2018a), IOSC (2018), and Kroeber (2018). 
While the share of medium- and high-tech products in NAF TA's exports to China has fallen -from above 50 percent until 2002, to below 30 percent in several recent years- NAFTA's imports from China of the same types of goods have increased from about 20 percent in the early 1990s to above 50 percent since 2009 and 56.84 percent in 2017 (Figure 1). At least as important is the fact that NAFTA has had an increasing trade deficit with China in these goods since the early 1990s -from Us $\$ 1.1$ billion in 1991 to us $\$ 33$ billion in 2000, us \$219.5 billion in 2010 , and us $\$ 312.6$ billion in 2017 - rather counterintuitively, since in 2010 more than 60 percent of NA FTA's trade deficit with China occurred in these categories.

Figure 1. Percentage of medium- and high-tech goods in NAFTA's trade with China, 1993-2017

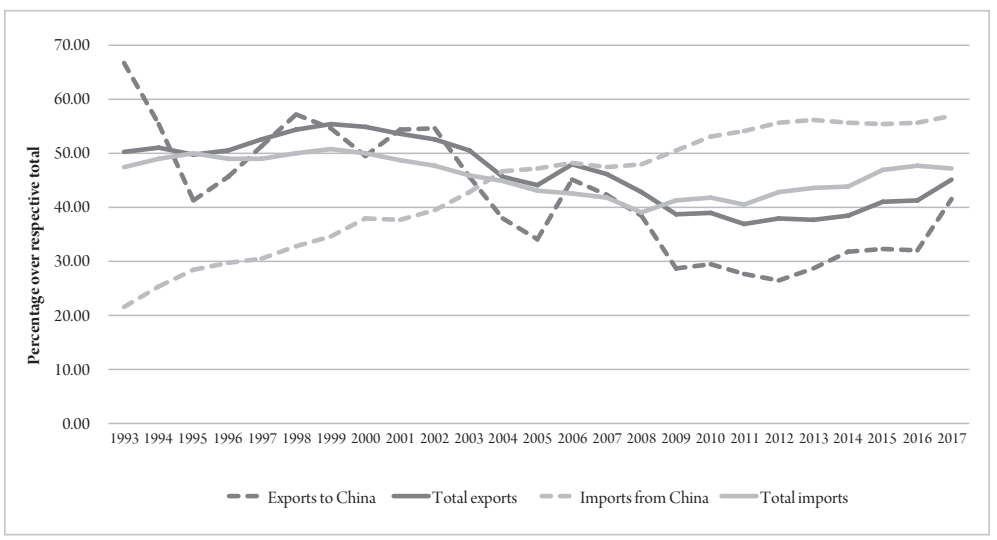

Data source: CECHIMEX (2018).

Figure 2 shows this trend for 1992-2017 from several perspectives. Intraregional trade was lower in 2017 than at the beginning of NAF TA (42.11 percent in 1994 and 39.79 percent in 2017); import levels particularly dropped (from 37.33 percent to 33.08 percent). China has played a substantial role in this regional disintegration: its presence in NAFTA's trade grew from 3.42 percent in 1994 to 14.91 percent in 2017. While China still plays a relatively minor role as a recipient of N A F TA's exports, 
accounting for 6.88 percent in 2017, NAFTA's imports from China increased from 4.87 percent in 1994 to 20.10 percent in 2017. Thus, the NAFTA region presents a massive trade deficit; the import-to-export ratio was 4.4 to 1 in 2017. From this perspective, China is the region's second largest trading partner, after the United States, with a share of 19.30 percent in 2017. Since 2007, China has overtaken the United States to become the biggest importer of NAFTA products.

Figure 2. NAFTA's intra-regional trade and trade with China, 1992-2017

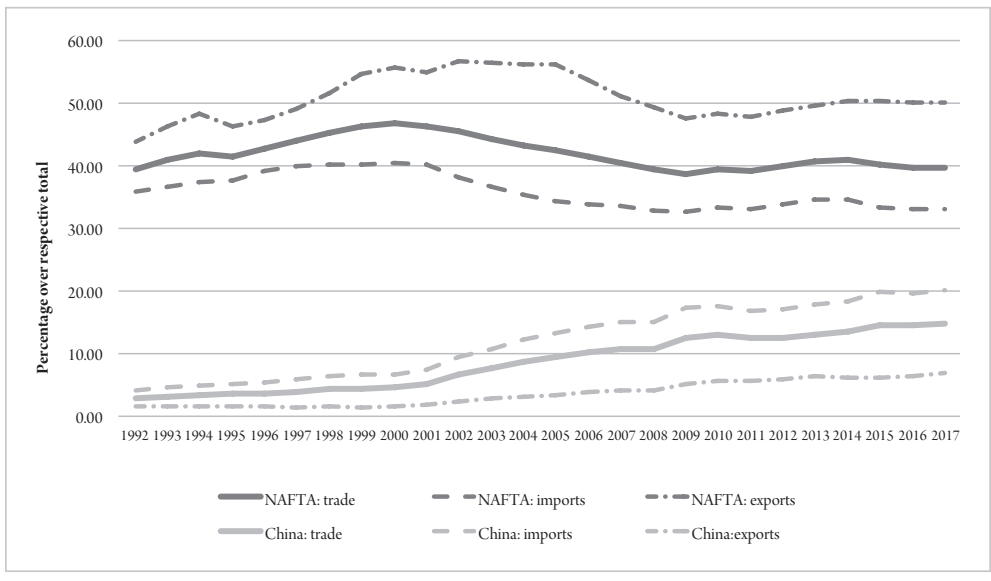

Data source: CECHIMEX (2018).

Table 1 disaggregates data on trade within NAFTA based on categories established by the Harmonized TariffSchedule. N A FTA's total trade with China in the top 10 trade categories (ranked based on 2017 statistics) fell from 54.31 percent of total trade in 2010 to 48.31 percent in 2017. For some chapters, the decrease in NAFTA imports from China during this period was minor; for example, the share of NAFTA's umbrella imports from China fell from 93.33 percent of total imports in 2010 to 91.84 percent in 2017. In most cases, however, and significant for this discussion, there were steep declines in China's share; for footwear, for example, China's share fell 19.69 percent during this period. The same table highlights the importance of three critical categories: auto parts, 
The New Triangular Relationship Between Mexico, the United States, and China

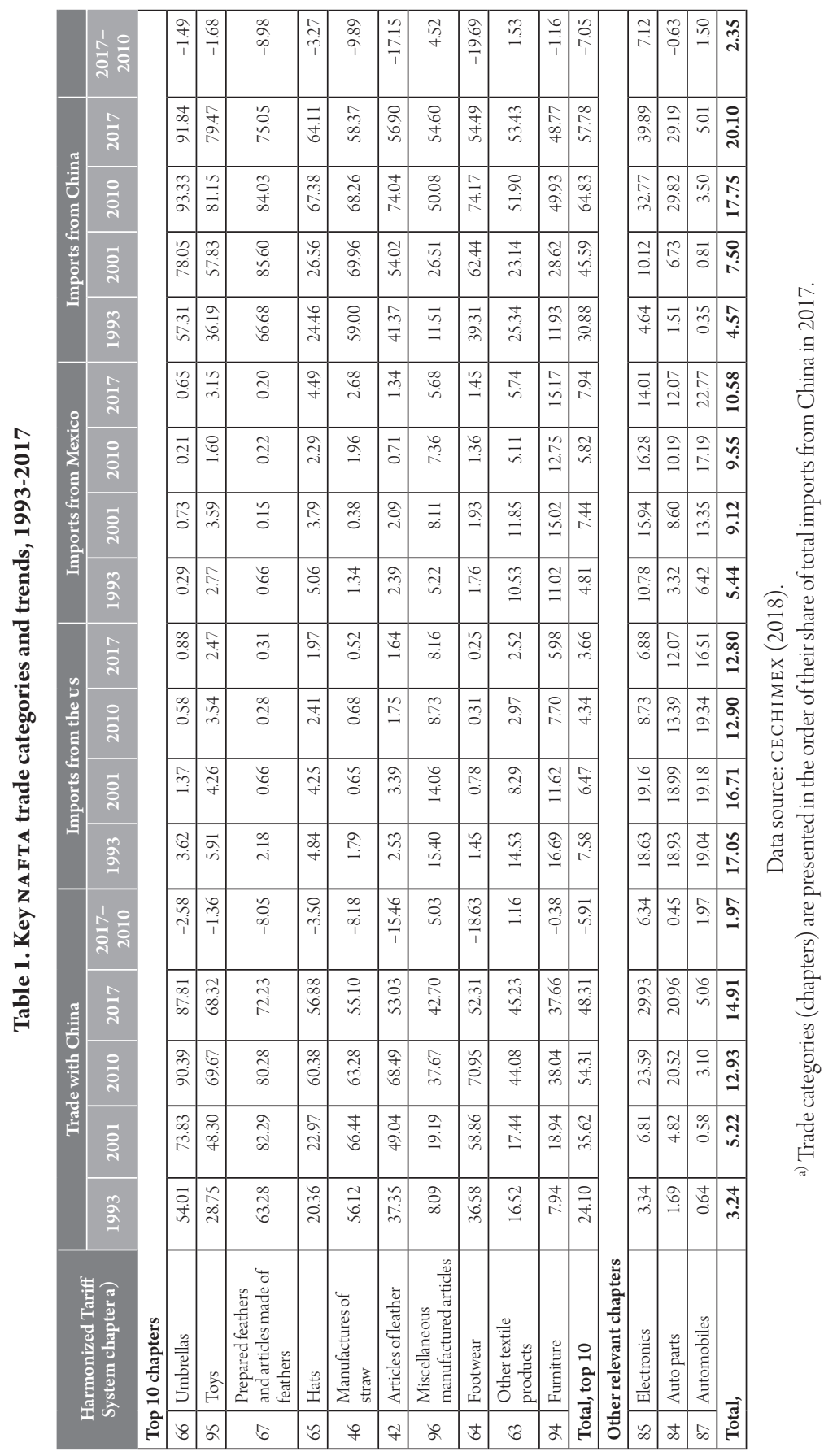


automobiles, and electronics. While the share of Chinese imports in NAFTA has been relatively constant for auto parts and automobiles, electronics account for the highest increase in the share of NA FTA's imports, growing 7.12 percent from 2010 to 2017 . China is the main importer of auto parts and electronics from NAFTA countries.

\section{China's trade presence in Mexico}

Since 2003, China has become Mexico's second most important trading partner, after the United States. This trade relationship shows the following features (Dussel Peters and Levy-Dabbah 2018; Yang 2016):

- Mexican imports from and exports to China have been extremely dynamic, with an average annual growth rate of 25.7 percent in 1993 and 24.3 percent in 2017, much higher than Mexico's overall imports and exports, which were 8.4 percent and 9.4 percent, respectively.

- China's share in Mexico's trade increased from below 1 percent in 2001 to 9.74 percent in 2017, particularly as a result of China's growing share in Mexican imports, which increased from below 2 percent in 2000 to 17.64 percent in 2017. In comparison, the Us share in Mexican trade fell from its maximum of 81.03 percent in 1999 to 62.84 percent in 2017; the decrease in the share of Mexico's imports originating in the United States was even more dramatic for this period, from 74.38 percent to 46.28 percent.

- Mexico's trade deficit with China has been substantial, accounting for more than US $\$ 60$ billion annually since 2014, with an import/ export ratio of 11.05 to 1 in 2017.

- The proportion of intra-industry trade in overall trade has recently been around 42 percent for Mexico and the United States, but only 10 percent for Mexico and China.

- There is an important gap in terms of medium- and high-technology products: Mexican imports from China have accounted for 


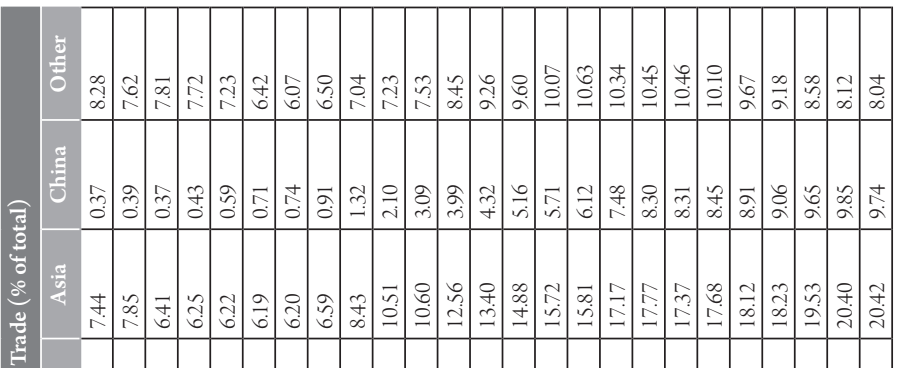

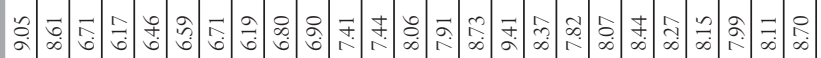

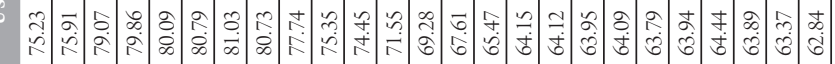

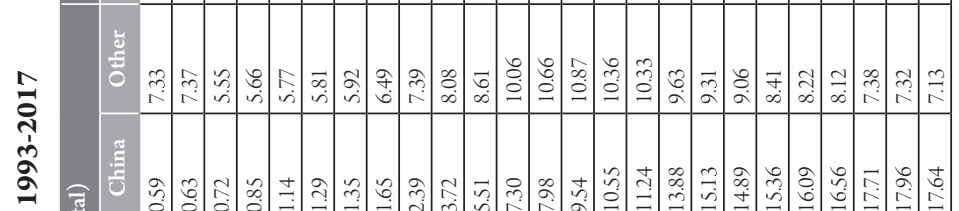



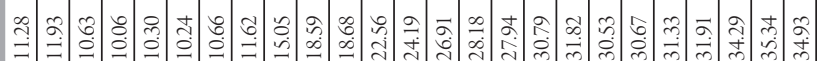

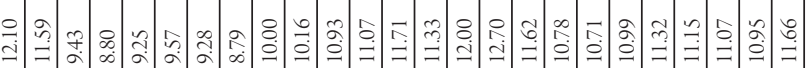

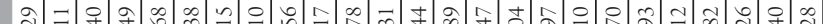

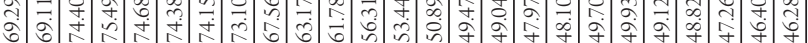

(2)

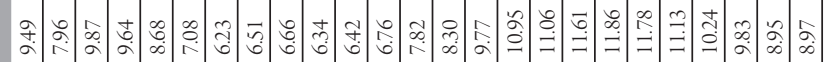

芒

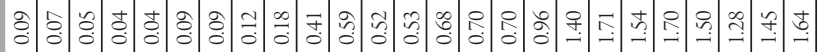

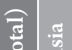

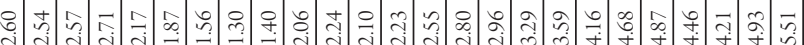

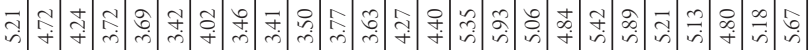

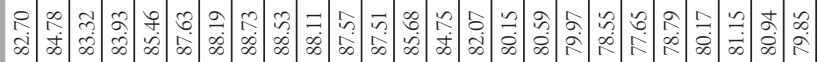

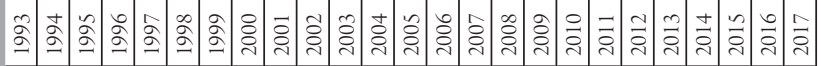


about 70 percent of total imports in the last decade, and Mexican exports to China for only about 40 percent. While lower than its import rate, this is still the highest export rate of any country in Latin America and the Caribbean.

Table 3 shows additional disaggregated tendencies in Mexico's trade with the United States and China in key trade categories. Chinese imports have achieved a profound penetration of the Mexican market since the beginning of NAFTA. In the 10 top trade categories, the Chinese share of Mexico's total imports increased from 15.59 percent in 1995 to 61.36 percent in 2017. The most dynamic growth in Chinese imports occurred in 2001-2010, after China's accession to the World Trade Organization; since then, imports have continued to grow, but much more slowly.

While not in the top 10, three other trade categories are highly relevant: electronics, auto parts, and automobiles probably constitute the core of NA FTA's integration process, and in these, Mexico has been extremely successful. In each of these global value chains, Chinese imports have massively penetrated Mexico's economy and imports. In the case of automobiles, the presence is still at a low level, accounting for 3.43 percent of total Mexican imports in 2017. In the case of electronics, however, Chinese imports increased from 3.20 percent of Mexican imports in 2001 to 35.47 percent in 2017; China has become the most important country of origin for Mexican imports in this category.

The share of Mexican imports originating in the United States decreased substantially in this period, particularly since 2001, that is, the former disintegration process of NAFTA. This process has also occurred within NA FTA's trade, not only in the top 10 Chinese import categories, but also in electronics, auto parts, and automobiles. In the case of electronics, for example, the share of us imports in Mexico fell from 65.80 percent in 2001 to 14.75 percent in 2017. 
The New Triangular Relationship Between Mexico, the United States, and China

\begin{tabular}{|c|c|c|c|c|c|c|c|c|c|c|c|c|c|c|c|c|c|c|c|}
\hline & 돌 & & ? & $\stackrel{\text { બે }}{i}$ & గిర్రి & $\begin{array}{l}\vec{F} \\
\stackrel{i}{1}\end{array}$ & $\begin{array}{l}R \\
\text { i } \\
\text { in }\end{array}$ & $\begin{array}{c}\stackrel{+}{+} \\
+ \\
+\end{array}$ & బิ & 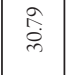 & $\stackrel{\infty}{\stackrel{-}{=}}$ & $\begin{array}{c} \pm \\
\stackrel{\sigma}{\sigma}\end{array}$ & 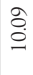 & & & 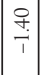 & $\stackrel{0}{0}$ & $\vec{n}$ & \\
\hline 동 & ลे & & $\begin{array}{l}\overrightarrow{0} \\
\stackrel{0}{\infty}\end{array}$ & $\vec{\alpha}$ & \begin{tabular}{l} 
\pm \\
\multirow{i}{*}{} \\
$\mathrm{i}$
\end{tabular} & $\begin{array}{l}\text { त̂ } \\
\text { Rุ }\end{array}$ & $\begin{array}{l}\text { के } \\
\text { ठे }\end{array}$ & $\begin{array}{l}\infty \\
\dot{w} \\
\dot{n}\end{array}$ & $\begin{array}{l}\text { जे } \\
\text { in }\end{array}$ & 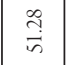 & $\mid \begin{array}{l}2 \\
\ddot{q} \\
\dot{q}\end{array}$ & 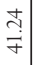 & 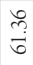 & & $\begin{array}{l}\vec{f} \\
\dot{w} \\
\dot{n}\end{array}$ & $\left|\begin{array}{l}\hat{\hat{j}} \\
\hat{\jmath}\end{array}\right|$ & 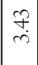 & 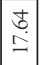 & \\
\hline$\frac{0}{3}$ & ลें & & 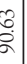 & 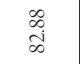 & 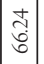 & 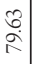 & $\mid \begin{array}{l}\text { ते } \\
\vec{b}\end{array}$ & $\stackrel{m}{\circ}$ & $\begin{array}{l}\overrightarrow{5} \\
\vec{b}\end{array}$ & $\begin{array}{l}0 \\
\text { on } \\
\text { ¿n }\end{array}$ & $\begin{array}{l}\infty \\
\infty \\
\infty \\
\infty\end{array} \mid$ & $\frac{q}{\dot{m}}$ & $\hat{\hat{a}}$ & & 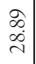 & $\mid \begin{array}{l}\vec{\partial} \\
\vec{i}\end{array}$ & $\stackrel{3}{\curvearrowright}$ & $\frac{m}{\vec{n}}$ & \\
\hline 目 & ఫ్ ి & & 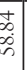 & $\begin{array}{l}\infty \\
\stackrel{\infty}{\infty} \\
\infty \\
1\end{array}$ & $\begin{array}{l} \pm \\
\stackrel{+}{q}\end{array}$ & 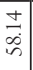 & $\stackrel{\partial}{\partial}$ & $\begin{array}{l}0 \\
\dot{0} \\
\vec{z}\end{array}$ & 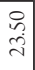 & $\underset{\text { f }}{\text { f }}$ & $\underset{i}{J}$ & $\stackrel{ }{=}$ & $\begin{array}{l}\tilde{N} \\
\text { त̂̀ }\end{array}$ & & $\begin{array}{l}\text { ते } \\
\text { ल) }\end{array}$ & $\begin{array}{c}0 \\
i \\
i\end{array}$ & lo & $\mid \begin{array}{c}\hat{n} \\
\mathrm{i}\end{array}$ & \\
\hline & ஓे & & $\begin{array}{l}8 \\
0 \\
\infty \\
i \\
n\end{array}$ & $\stackrel{\circ}{\stackrel{0}{\pi}}$ & 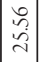 & $\begin{array}{c}\tilde{\alpha} \\
\vdots \\
\vdots \\
\vdots\end{array}$ & 哭 & 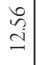 & $\begin{array}{c}\stackrel{f}{f} \\
\stackrel{d}{\rightarrow}\end{array}$ & 守 & \begin{tabular}{l}
$\infty$ \\
$\infty$ \\
$\infty$ \\
\hdashline
\end{tabular} & 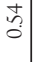 & $\begin{array}{l}\vec{\partial} \\
\stackrel{\vec{n}}{-}\end{array}$ & & \begin{tabular}{l|}
$\overrightarrow{0}$ \\
$\dot{0}$
\end{tabular} & $\mid$\begin{tabular}{c}
$\infty$ \\
\hdashline \\
0
\end{tabular} & . & בి & \\
\hline \multirow{5}{*}{ 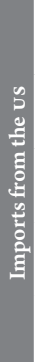 } & ํㅗㄱ & & $\begin{array}{l}3 \\
3 \\
3\end{array}$ & $\stackrel{m}{\rightarrow}$ & $\begin{array}{c}+ \\
\stackrel{m}{i} \\
\stackrel{i}{*}\end{array}$ & 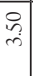 & $\begin{array}{l}0 \\
1 \\
1 \\
1 \\
1\end{array}$ & 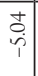 & 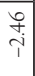 & $\underset{⿱ 亠 䒑}{\stackrel{ \pm}{p}}$ & $\begin{array}{l}\stackrel{y}{\dagger} \\
\dot{m}\end{array}$ & $\begin{array}{l}\text { fo } \\
+ \\
\dot{f}\end{array}$ & 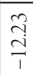 & & 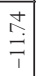 & $\mid \begin{array}{c}2 \\
\hat{i} \\
\hat{i}\end{array}$ & $\mid \begin{array}{l}0 \\
6 \\
1 \\
1\end{array}$ & 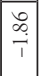 & \\
\hline & สี & & 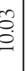 & $\begin{array}{l}\infty \\
\text { ¿ } \\
\text { i }\end{array}$ & $\begin{array}{l}2 \\
2 \\
0 \\
0\end{array}$ & $\begin{array}{l}\infty \\
\vec{n}\end{array}$ & $\mid \begin{array}{c}0 \\
\infty \\
\stackrel{0}{0}\end{array}$ & $\begin{array}{l}\hat{A} \\
\stackrel{D}{-}\end{array}$ & $\overrightarrow{\vec{b}}$ & 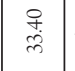 & ปे & 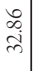 & $\underset{\infty}{\tilde{D}}$ & & $\begin{array}{l}\stackrel{n}{+} \\
\dot{+}\end{array}$ & 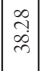 & $\mid \begin{array}{c}\hat{\sigma} \\
\dot{\delta} \\
\dot{f}\end{array}$ & $\begin{array}{l}\hat{2} \\
\hat{\sigma} \\
+\end{array}$ & \\
\hline & 을 & & \begin{tabular}{l}
8 \\
\hdashline \\
+ \\
+
\end{tabular} & ळे & 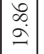 & $\stackrel{\infty}{\stackrel{\infty}{-}}$ & $\begin{array}{l}\tilde{2} \\
\cong\end{array}$ & $\begin{array}{l}\overrightarrow{\tilde{Z}} \\
\vec{\sim}\end{array}$ & 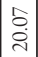 & 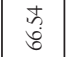 & \begin{tabular}{|l} 
A \\
i
\end{tabular} & $\begin{array}{c}\vec{m} \\
\vec{m}\end{array}$ & $\begin{array}{l}\text { مे } \\
\text { ठें }\end{array}$ & & 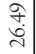 & 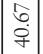 & 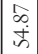 & 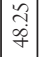 & \\
\hline & ఫ్ & & 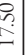 & 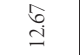 & $\left|\begin{array}{l}3 \\
0 \\
0 \\
0\end{array}\right|$ & 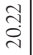 & ळे & 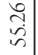 & $\begin{array}{c}\hat{b} \\
\vec{m} \\
\tilde{m}\end{array}$ & 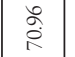 & 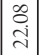 & $\begin{array}{l}\curvearrowright \\
\stackrel{े}{\circ}\end{array}$ & $\begin{array}{l}n \\
\infty \\
n \\
n \\
n\end{array}$ & & $\begin{array}{l}\infty \\
\dot{0} \\
\dot{b}\end{array}$ & $\mid$\begin{tabular}{c}
\multirow{2}{z}{} \\
$\stackrel{n}{n}$
\end{tabular} & $\begin{array}{l}2 \\
2 \\
0 \\
0\end{array}$ & $\mid \begin{array}{l}2 \\
\vdots \\
6\end{array}$ & \\
\hline & ळे & & $\begin{array}{l}\vec{a} \\
\text { c. } \\
m\end{array}$ & $\begin{array}{l}\stackrel{\infty}{\stackrel{n}{\sim}} \\
\stackrel{\sim}{\sim}\end{array}$ & 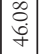 & $\begin{array}{l}\text { तี } \\
\text { तू }\end{array}$ & $\mid \begin{array}{c}\vec{N} \\
i \\
i n\end{array}$ & $\stackrel{\tilde{\alpha}}{\tilde{r}}$ & \begin{tabular}{|l}
$\vec{n}$ \\
$\stackrel{+}{5}$
\end{tabular} & $\begin{array}{l}\tilde{n} \\
\tilde{\infty} \\
\infty\end{array}$ & $\stackrel{\circ}{\circ}$ & $\begin{array}{c}\tilde{\infty} \\
\vec{a} \\
\vec{a}\end{array}$ & $\stackrel{=}{\vec{b}}$ & & $\begin{array}{l}\text { 童 } \\
\vdots \\
1\end{array}$ & $\mid \begin{array}{l}3 \\
-0 \\
-1\end{array}$ & $\begin{array}{l}0 \\
\dot{D} \\
\dot{\infty}\end{array}$ & \begin{tabular}{|l} 
守 \\
$\underset{1}{+}$
\end{tabular} & \\
\hline \multirow{5}{*}{ 焉 } & 돌을 & & $\stackrel{\circ}{=}$ & $\underset{\hat{i}}{\tilde{i}}$ & $\left|\begin{array}{l}0 \\
0 \\
i \\
i\end{array}\right|$ & $\begin{array}{l}2 \\
\vdots \\
0 \\
-1\end{array}$ & $\stackrel{\sim}{\infty}$ & $\underset{i}{\stackrel{\partial}{i}}$ & $\begin{array}{c}2 \\
\mathfrak{w} \\
+\end{array}$ & $\frac{m}{m}$ & $\begin{array}{l}\infty \\
\stackrel{\infty}{+}\end{array}$ & $\stackrel{\circ}{\rightarrow}$ & $\begin{array}{l}\text { ஓे } \\
\text { iे }\end{array}$ & & 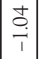 & $\begin{array}{l}0 \\
\stackrel{1}{1} \\
7\end{array}$ & $\stackrel{2}{a}$ & $\stackrel{2}{\rightarrow}$ & \\
\hline & तें & & 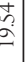 & ڤ̆ & $\begin{array}{l}\infty \\
\infty \\
\dot{\gamma} \\
\tilde{f}\end{array}$ & $\begin{array}{l}0 \\
1 \\
3 \\
0\end{array}$ & 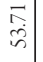 & $\begin{array}{c}0 \\
\vdots \\
\vdots \\
m\end{array}$ & $\begin{array}{l}\hat{2} \\
\hat{n}\end{array}$ & $\frac{ \pm}{\infty}$ & $\stackrel{2}{\therefore}$ & $\begin{array}{l}8 \\
+ \\
+ \\
\end{array}$ & $\hat{\hat{\alpha}}$ & & $\begin{array}{l}+ \\
\dot{f} \\
\dot{w}\end{array}$ & $\mid \begin{array}{l}0 \\
\stackrel{2}{2} \\
\end{array}$ & $\begin{array}{c}0 \\
0 \\
r^{p}\end{array}$ & 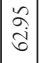 & \\
\hline & 을 & & 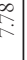 & $\begin{array}{l}\stackrel{8}{\mathrm{j}} \\
\text { הi }\end{array}$ & 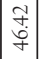 & $\begin{array}{l}\vec{\infty} \\
\dot{\sigma} \\
\vec{y}\end{array}$ & $\mid \begin{array}{c}\stackrel{\partial}{\vec{d}} \\
\dot{\mathrm{n}}\end{array}$ & $\begin{array}{l}q \\
q \\
\dot{m}\end{array}$ & $\begin{array}{l}\overrightarrow{0} \\
\dot{n} \\
\end{array}$ & $\begin{array}{l}\text { ff } \\
\text { d: }\end{array}$ & $\begin{array}{l} \pm \\
\text { ¿े } \\
\end{array}$ & $\stackrel{0}{\vec{n}}$ & 吾 & & $\begin{array}{l}\infty \\
\vdots \\
i \\
i n\end{array}$ & $\left|\begin{array}{l}0 \\
\tilde{D} \\
\text { రె }\end{array}\right|$ & $\begin{array}{l}\vec{r} \\
\hat{\sigma}\end{array}$ & $\mid \begin{array}{l}0 \\
\dot{b} \\
\dot{b}\end{array}$ & \\
\hline & ఫิં & & 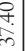 & 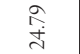 & 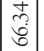 & 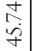 & $\begin{array}{l}\stackrel{1}{ \pm} \\
\stackrel{2}{ \pm}\end{array}$ & $\begin{array}{l}0 \\
\vdots \\
0\end{array}$ & $\begin{array}{l}3 \\
\stackrel{3}{0}\end{array}$ & 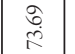 & $\mid \begin{array}{c}2 \\
\overrightarrow{\mathrm{d}} \\
\mathbf{i}\end{array}$ & $\vec{\sigma}$ & $\begin{array}{l}\text { to } \\
\\
\end{array}$ & & $\begin{array}{l}\bar{n} \\
\overline{2}\end{array}$ & $\stackrel{2}{\stackrel{i}{i}}$ & $\mid \begin{array}{l}2 \\
\hat{D} \\
\dot{\infty}\end{array}$ & 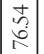 & \\
\hline & ๘ & & $\begin{array}{l}0 \\
\vdots \\
\vdots \\
n \\
n\end{array}$ & $\stackrel{\vec{m}}{\vec{m}}$ & $\mid \begin{array}{l}\vec{\infty} \\
\stackrel{+}{\perp}\end{array}$ & 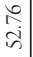 & $\left|\begin{array}{c}\infty \\
0 \\
i \\
\infty \\
\infty\end{array}\right|$ & $\begin{array}{l}0 \\
\vec{b} \\
\infty\end{array}$ & $\begin{array}{c}2 \\
\vec{b} \\
\infty\end{array}$ & $\begin{array}{l}n \\
\text { ถి }\end{array}$ & $\vec{n}$ & 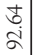 & $\begin{array}{l}\text { के } \\
\text { वे }\end{array}$ & & $\begin{array}{l}\infty \\
\infty \\
\infty \\
\infty \\
\infty\end{array}$ & \begin{tabular}{|l|l}
$\stackrel{0}{2}$ \\
$\stackrel{2}{R}$
\end{tabular} & 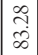 & $\frac{1}{2}$ & \\
\hline \multirow{5}{*}{ 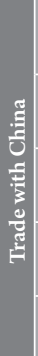 } & 촣ํํำ & & $\begin{array}{c}\vec{\sigma} \\
\bar{z} \\
\end{array}$ & $\stackrel{ઈ}{\ni}$ & 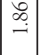 & $\overrightarrow{\overrightarrow{0}}$ & $\underset{\substack{\mathfrak{i} \\
\underset{i}{i}}}{\mid}$ & $\begin{array}{c}\infty \\
\stackrel{\infty}{i} \\
\end{array}$ & $\underset{\hat{i}}{\hat{i}}$ & $\begin{array}{l}0 \\
0 \\
\infty \\
d\end{array}$ & बे & బે) & $\underset{\sim}{\stackrel{d}{d}}$ & & $\begin{array}{c}\tilde{m} \\
\stackrel{i}{1}\end{array}$ & $\stackrel{\infty}{\infty}$ & 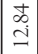 & 寺 & \\
\hline & 후 & & $\frac{7}{6}$ & है & 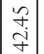 & $\begin{array}{l}8 \\
\stackrel{2}{+} \\
\stackrel{+}{+}\end{array}$ & 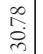 & $\begin{array}{l}\text { 声 } \\
\dot{+}\end{array}$ & $\begin{array}{l}0 \\
3 \\
3 \\
\end{array}$ & $\begin{array}{c}\text { 崩 } \\
\text { oे }\end{array}$ & $\begin{array}{l}\stackrel{0}{\circ} \\
\stackrel{+}{+}\end{array}$ & $\begin{array}{l}\circ \\
\stackrel{0}{ \pm} \\
\end{array}$ & $\begin{array}{l}\text { S. } \\
\text { d. }\end{array}$ & & $\begin{array}{l}\stackrel{゚}{+} \\
\stackrel{1}{+}\end{array}$ & \begin{tabular}{|l|}
$\circ$ \\
$\stackrel{0}{ \pm}$ \\
\end{tabular} & 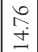 & 志 & \\
\hline & 을 & & $\begin{array}{l} \pm \\
\dot{\infty}\end{array}$ & $\begin{array}{l}\text { fo } \\
\text { gi }\end{array}$ & 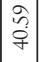 & $\begin{array}{l}\hat{\sigma} \\
\dot{q}\end{array}$ & 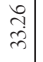 & $\begin{array}{l}\infty \\
\infty \\
\infty \\
\infty\end{array}$ & $\mid \begin{array}{l}\hat{3} \\
\hat{3} \\
\end{array}$ & $\begin{array}{l}\stackrel{\bullet}{0} \\
\stackrel{0}{2}\end{array}$ & $\begin{array}{c}0 \\
0 \\
\infty \\
m\end{array}$ & $\stackrel{ \pm}{\stackrel{ \pm}{\Xi}}$ & $\begin{array}{l}\text { 崩 } \\
\text { లై }\end{array}$ & & 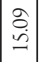 & $\overrightarrow{\vec{\jmath}}$ & $\stackrel{2}{-}$ & $\begin{array}{c}0 \\
\infty \\
\infty \\
\infty\end{array}$ & \\
\hline & ర్ & & $\begin{array}{l}\vec{y} \\
\dot{f} \\
\dot{y}\end{array}$ & $\begin{array}{l}6 \\
6 \\
6\end{array}$ & $\begin{array}{l}\stackrel{g}{\grave{g}} \\
\dot{\Omega}\end{array}$ & 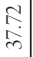 & 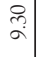 & 它 & 艿 & $\underset{\text { ָ̦ }}{\text { Sa }}$ & $\begin{array}{l}\stackrel{f}{i} \\
\mathrm{i}\end{array}$ & $\tilde{\Xi}$ & 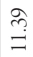 & & $\left.\begin{array}{l}0 \\
0 \\
0 \\
0\end{array}\right]$ & \begin{tabular}{|l|}
$\infty$ \\
$\vdots$ \\
0
\end{tabular} & $\mid \begin{array}{l}0 \\
0 \\
\end{array}$ & $\stackrel{+}{\rightarrow}$ & \\
\hline & ळ & & 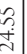 & $\begin{array}{l}m \\
\infty \\
o \\
\dot{f}\end{array}$ & $\begin{array}{l}8 \\
8 \\
0\end{array}$ & 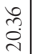 & $\mid \begin{array}{l}0 \\
i \\
i n\end{array}$ & $\begin{array}{l}8 \\
\dot{n}\end{array}$ & $\mid \begin{array}{l}\infty \\
0 \\
0\end{array}$ & ठே. & $\stackrel{\sim}{\stackrel{\sim}{\mathrm{N}}}$ & 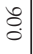 & $\overrightarrow{\vec{r}}$ & & $\tilde{c}$ & $\overrightarrow{\tilde{O}}$ & $\vec{\Delta}$ & के & \\
\hline \multirow{2}{*}{\multicolumn{2}{|c|}{ 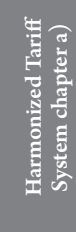 }} & 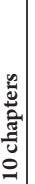 & है & 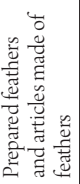 & 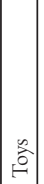 & 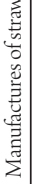 & $\begin{array}{l}0 \\
\mathbb{3} \\
\mathbb{Z}\end{array}$ & 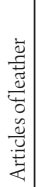 & 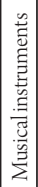 & 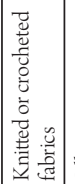 & 湇 & 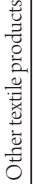 & $\stackrel{8}{\circ}$ & 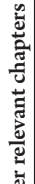 & 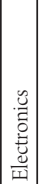 & 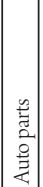 & 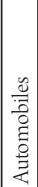 & \multirow{2}{*}{ 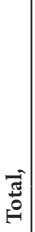 } & \\
\hline & & 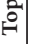 & 8 & 6 & 2 & f & 18 & ₹ & $\alpha$ & 8 & 8 & 8 & 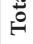 & 苛 & $\infty$ & $\Phi$ & $\infty$ & & \\
\hline
\end{tabular}




\section{Final reflections and proposals}

Regardless of recent bilateral tensions between the Trump administration and China and Mexico, this chapter has shown that China's trade presence, both in the NA FTA region as a whole and in Mexico, has been broad and deep since China's accession to the World Trade Organization in 2001. The increasing disintegration of NAFTA since then, from this perspective, is a result of China's increasing activity in the region. China has been the main trading partner of the United States since 2016 and the second in importance for Mexico since 2003.

This process has been ongoing for more than 15 years. It has been particularly profound in crucial manufacturing sectors such as electronics and auto parts/automobiles, both for the NA FTA region as a whole and for Mexico (Dussel Peters 2018). And it has been especially notable for NAFTA's and Mexico's imports from China of medium and hightech products, which have been much greater than Mexico's or NA FTA's exports of similar products to China. Understanding this gap is critical to understanding the current discussions between the Trump administration and China. Interestingly, China's share of NAF TA's imports in China's top imports has fallen recently. In brief, China is a major challenge not only for the United States but also for NA FTA and Mexico.

From this perspective, the renegotiation of NA FTA and future discussions within NA FTA should explicitly include China, since it challenges the integration of the region and has massively displaced the United States in terms of trade. In addition, the NA FTA region should explicitly allow for instruments and mechanisms to deepen regional integration, in fields such as in electronics, auto parts, and automobiles, vis à vis other trading partners such as the European Union, Asia, and China. A "Us only" approach to the renegotiation of NAFTA is clearly insufficient, as the document clearly highlights, since the region as a whole is deeply challenged by China's increasing presence in the region and globally. 


\section{References}

Dussel Peters, Enrique. 2018a. "La renegociación del TlCAN: Efectos arancelarios y el caso de la cadena del calzado." Investigación Económica 77 (303): 3-51.

Dussel Peters, Enrique. 2018b. Monitor of Chinese ofdi in Latin America and the Caribbean. Mexico City: Red ALC-China.

Dussel Peters, Enrique, and Simón Levy-Dabbah, editors. 2018. Hacia una agenda estratégica México-China. Mexico City: UnA M/CECH IMEX, Agendasia and comeXI.

Dussel Peters, Enrique, and Samuel Ortiz Velásquez. 2016. "El Tratado de Libre Comercio de América del Norte, ¿contribuye China a su integración o desintegración?" In La nueva relación comercial de América Latina y el Caribe con China, integración o desintegración regional?, edited by Enrique Dussel Peters, 245-308. Mexico City: Red ALCChina, UdUAL y UNAM/CECHIMEX.

I Os C (Information Office of the State Council of the People's Republic of China). 2018. The Facts and China's Position on China-Us Trade Friction. Beijing: I OS C.

Kroeber, Arthur. 2018. "Digging in for a War of Attrition." Dragonomics, September 18, 2018.

Moreno Brid, Juan Carlos, Isabel Salat, and Joaquín Sánchez. 2018. "Comercio exterior y crecimiento económico en México: más allá de la renegociación del T LC AN." Investigación Económica 77 (303): 58-75. Yang, Zhimin. 2016. "México y China: condiciones y propuestas desde una perspectiva china." In La relación México-China: Desempeño y propuestas para 2016-2018, edited by Enrique Dussel Peters, 38-48. Mexico City: UnAm/CeCHIMEX and MEXCHam. 



\section{The Role of Trade with China in Mexico's Renegotiation of NAFTA}

Simón Levy-Dabbah

Mexico, Canada, and the United States are in the middle of important negotiations regarding the North American Free Trade Agreement (NAFTA). Due to pressure from the United States, a process was initiated which was necessary but which could have been proposed by Mexico and could have been a positive process of modernization and improvement, instead of the media show initiated by the president of the United States. Instead of negotiating proactively and effectively, Mexico began negotiations under pressure and threats to cancel NAFTA.

There is another participant behind the scenes who, despite not belonging geographically to North America, has an influential role and a strong interest in these events: China.

When NAFTA went into effect in 1994, the United States was already Mexico's most important trading partner, while trade with China was practically nil. There was no market for Mexican products in China, and Mexico imported mostly inexpensive and low-quality products from the Asian giant. Since there was no treaty between the two countries, import tariffs on many products were high, limiting the access of Chinese products to Mexico. Even so, during the 1990s, imports of Chinese products to Mexico grew exponentially, especially since the entry into force of NA FTA, a period in which the growth of imports from China averaged 30 percent per year. 
At the same time, trade between China and the United States was growing rapidly, with a large deficit from the beginning for the United States. The move of the us manufacturing base to China gained momentum, driven by low labor costs and high availability, as well as the facilities that the Chinese government was granting to transnational corporations for the creation of factories in its territory. Thanks to this opening, the US trade relationship with China grew at an average rate of 14 percent per year during the 1990s, increasing the us trade deficit from a little over U $\$ 40$ billion at the beginning of that decade to more than u $\$ 80$ billion in the year 2000.

Despite the high tariffs that Mexico imposed on products from China, imports of Chinese goods to Mexico increased substantially during the 1990s, driven significantly by NAFTA, as one of its effects was the transfer of a part of the Us manufacturing industry to Mexico, which was competing with China in this regard. China, as part of its growth strategy, supplied raw materials and intermediate goods to Mexican factories, which used them in the manufacture of goods for export to the United States. This accounted for a substantial part of the growth in imports from China to Mexico.

During the last years of the $20^{\text {th }}$ century, China entered negotiations for entry into the World Trade Organization (w TO). An issue of central importance for China was to obtain the tariff benefits that membership would allow with all w T O member countries, including Mexico. China achieved this goal in 2001, which eliminated practically all tariff barriers in member countries. During the first decade of the millennium, a significant increase in world trade was observed, due to a global trend toward trade opening and a favorable economic environment for trade. China took advantage of this to expand its exports, with the approval of the w T O. Its main customer, of course, was the United States.

Similarly, during 2001-2017, trade between Mexico and the United States intensified. Exports from Mexico to its northern neighbor increased by 134 percent during this period, from U $\$ 140$ billion in 2001 to us $\$ 327$ billion in 2017. During the same period, imports to Mexico from the United States only grew by 74 percent, from us $\$ 113$ billion 
Table 1. Imports from China to Mexico and the United States, 1997-2017

\begin{tabular}{|c|c|c|c|c|c|c|}
\hline & \multicolumn{3}{|c|}{ US-China Trade } & \multicolumn{3}{c|}{ Mexico-China Trade } \\
\hline & Exports & Imports & Balance & Exports & Imports & Balance \\
\hline 1997 & 12.86 & 62.56 & -49.70 & 0.05 & 1.25 & -1.20 \\
\hline 1998 & 14.24 & 71.17 & -56.93 & 0.11 & 1.62 & -1.51 \\
\hline 1999 & 13.11 & 81.79 & -68.68 & 0.13 & 1.92 & -1.80 \\
\hline 2000 & 16.19 & 100.02 & -83.83 & 0.20 & 2.88 & -2.68 \\
\hline 2001 & 19.18 & 102.28 & -83.10 & 0.28 & 4.03 & -3.75 \\
\hline 2002 & 22.13 & 125.19 & -103.06 & 0.65 & 6.27 & -5.62 \\
\hline 2003 & 28.37 & 152.43 & -124.07 & 0.97 & 9.40 & -8.43 \\
\hline 2004 & 34.43 & 196.68 & -162.25 & 0.99 & 14.37 & -13.39 \\
\hline 2005 & 41.19 & 243.47 & -202.28 & 1.14 & 17.70 & -16.56 \\
\hline 2006 & 53.67 & 287.77 & -234.10 & 1.69 & 24.44 & -22.75 \\
\hline 2007 & 62.94 & 321.44 & -258.51 & 1.90 & 29.74 & -27.85 \\
\hline 2008 & 69.73 & 337.77 & -268.04 & 2.04 & 34.69 & -32.65 \\
\hline 2009 & 69.50 & 296.37 & -226.88 & 2.21 & 35.53 & -33.32 \\
\hline 2010 & 91.91 & 364.95 & -273.04 & 4.18 & 45.61 & -41.43 \\
\hline 2011 & 104.12 & 399.37 & -295.25 & 5.96 & 52.25 & -46.28 \\
\hline 2012 & 110.52 & 425.62 & -315.10 & 5.72 & 56.94 & -51.22 \\
\hline 2013 & 121.75 & 440.43 & -318.68 & 6.47 & 61.32 & -54.85 \\
\hline 2014 & 123.66 & 468.47 & -344.82 & 5.96 & 66.26 & -60.29 \\
\hline 2015 & 115.93 & 483.19 & -367.26 & 4.87 & 69.99 & -65.11 \\
\hline 2016 & 115.60 & 462.62 & -347.02 & 5.41 & 69.52 & -64.11 \\
\hline 2017 & 130.37 & 505.60 & -375.23 & 6.71 & 74.15 & -67.43 \\
\hline
\end{tabular}

Source: United States Census Bureau and Secretaría de Economía. Note: The statistics are subject to change.

to us $\$ 195$ billion. The us trade deficit with Mexico grew from Us \$27 billion to US $\$ 132$ billion during the same period.

The growth of Chinese imports to the United States decreased after China's entry into the w TO, from an annual average of 14 percent in the 1990s to 10.5 percent during 2001-2017. During this period, the 
trade deficit between the two countries increased at an average rate of 9.9 percent per year. In comparison, China's trade with Mexico increased much more, growing at an average of 20 percent per year during the same period, as Chinese imports to Mexico increased from Us $\$ 4$ billion in 2001 to more than us \$74 billion in 2017. While Mexico has a trade surplus with the United States, its trade deficit with China grew during the same period at a rate of 19.8 percent per year, from U $\$ 1.2$ billion to more than us $\$ 67.4$ billion.

From 2001 (when China joined the w TO) to 2017, its trade with Mexico grew more than 18 times; in the same period, its trade with the United States grew a little less than five times. This is because the manufacture of consumer goods moved from the United States to Mexico as a result of NAFTA, thus reducing imports of Chinese intermediate goods to the United States while increasing those imports to Mexico. China's strategy of acting as a supplier of primary and intermediate goods caused Mexico to become an easement for the passage of Chinese goods to the United States.

The extent to which goods of Chinese origin are used in products exported from other countries is also shown in the increase of China's overall exports. In the case of North America, since the entry into force of NAFTA in 1994, and especially since China joined the WTO in 2001, Mexico has had greater participation in Chinese imports than the United States. In 2001, of all goods exported by China to the United States and Mexico, imports to Mexico made up 2 percent and imports to the United States made up 98 percent. In 2017, the same ratio was 12.8 percent to 87.2 percent.

China's large share in manufacturing in the United States can also be seen by comparing its trade surplus with the United States and Mexico. In 1997, the United States' deficit with China was 50 times greater than Mexico's; in 2001 this differential had been reduced to 25, and in 2017, to four. Given China's strategy of becoming a supplier of inputs for the manufacture of consumer goods, along with the transfer of the manufacture of these goods from the United States to Mexico, it can be inferred that some of the goods imported from China to Mexico will ultimately 
be transferred to the United States. It is important to identify the final destination of imports from China to Mexico.

Imports to Mexico from China during 1997-2017 can be compared with exports from Mexico to the United States during the same period, in terms of simple correlation, using the following formula:

$$
\operatorname{Correl}(X, Y)=\frac{\sum(x-\bar{x})(y-\bar{y})}{\sqrt{\sum(x-\bar{x})^{2} \sum(y-\bar{y})^{2}}}
$$

where $x$ represents imports from China to Mexico, $y$ represents exports from Mexico to the United States, and $\bar{x}$ and $\bar{y}$ are the sample means. Applying this formula yields a strong correlation -0.98073186 (for every Us $\$ 1.00$ of goods imported from China, U $\$ 0.98$ of goods are exported to the United States).

This result indicates that a significant amount of raw materials and intermediate goods imported from China to Mexico are eventually exported to the United States in the form of intermediate or finished products. In real terms, based on a simple comparison of imports from China with exports to the United States, for every us $\$ 10$ obtained by Mexico due to its trade surplus with the United States, there is an outflow of us $\$ 5$ due to its trade deficit with China.

To determine if there is indeed a triangulation of goods, the wTO and the Organization for Economic Cooperation and Development (OECD) recently created the Trade in Value Added initiative -an ambitious and complex system for identifying the origin by country of the inputs used to produce a good by following the value chain of all products involved in world trade-in other words, to document not only the import and export of goods between countries but also how much of a country's imports and exports come from a third country (OECD 2018). Because of its complexity, this initiative has completed documentation only for 1995 to 2011.

The value of goods imported from China to Mexico that are eventually exported to the United States can be estimated by comparing the 
amount of value-added inputs used in Mexico with the amount of goods exported to the United States from Mexico (Table 2).

Table 2. Estimated Chinese component in the value of Mexican goods exported to the United States, 1995-2011.

\begin{tabular}{|c|c|c|c|}
\hline & $\begin{array}{l}\text { Chinese-origin of } \\
\text { goods exported from } \\
\text { Mexico to the United } \\
\text { States }\end{array}$ & $\begin{array}{l}\text { Imports to Mexico } \\
\text { from China }\end{array}$ & $\begin{array}{l}\text { Percentage of } \\
\text { Chinese-origin goods } \\
\text { used in Mexican } \\
\text { exports to the United } \\
\text { States }\end{array}$ \\
\hline 1995 & us $\$ 222,140,000$ & Us $\$ 465,200,000$ & $47.75 \%$ \\
\hline 2000 & US\$1,439,900,000 & us $\$ 2,879,600,000$ & $50.00 \%$ \\
\hline 2005 & US $\$ 10,864,080,000$ & US $\$ 17,696,300,000$ & $61.39 \%$ \\
\hline 2009 & US $\$ 18,442,350,000$ & US $\$ 35,529,000,000$ & $51.91 \%$ \\
\hline 2010 & Us $\$ 23,256,840,000$ & US $\$ 45,607,600,000$ & $50.99 \%$ \\
\hline 2011 & US $\$ 27,421,620,000$ & US $\$ 52,248,000,000$ & $52.48 \%$ \\
\hline
\end{tabular}

Data sources: OECD, Trade in Value Added; Office of Economics Working Paper, Estimating Foreign Value-Added in Mexico's Manufacturing Exports; United States Census Bureau, Foreign Trade; Secretaría de Economía, world trade database.

This comparison suggests the following:

- Consistently, since the beginning of NAFTA, approximately 50 percent of goods imported into Mexico from China have been re-exported to the United States.

- Imported goods from China are mostly basic or primary goods and intermediate goods.

- These goods are used in manufacturing and exported to the United States in the form of consumer goods and intermediate goods, mainly in the automotive, aerospace, and telecommunications sectors.

Although the wage level in China is almost double that of Mexico, and the Mexican peso has depreciated against the Chinese yuan in the last four years by 44.5 percent and against the us dollar by 61.26 percent, the 
maquiladora model implemented by the Mexican government has not allowed Mexico to fully develop its potential. On the other hand, neither Mexico nor the United States have so far conducted negotiations with China of a similar magnitude to that of the NAFTA review; this signifies a clear commercial advantage for China, which continues to strengthen its technological development and industrial strategy.

In the context of the renegotiation of NAFTA, Mexico needs to consider the development of an industry driven by innovation in technologies and consumer goods, as well as moving from a maquiladora economy to an economy that allows an increase in productivity through greater integration of productive processes and the creation and transformation of sustained added value. Mexico must invest heavily in human capital to increase its competitiveness in order to compete in a world oriented toward what I call the mentefactura (mindfacture).

The current vision of NAFTA, in which Mexico is just a supplier of cheap labor and a host for maquiladoras, is clearly no longer working, nor will it generate improvement for Mexico in the long term. Mexican workers must receive more training, to increase both their productivity and their income prospects. Mexico must also seek, during negotiations, to obtain a greater transfer of knowledge and technology in order to develop an economy of learning and innovation.

Finally, Mexico must establish a new fiscal regime that promotes a new model of fiscal competitiveness, and especially, must create a model of specialization and guidance in terms of productivity, hand in hand with a clear and defined industrial policy that will enable the country to reach a level of global competitiveness that can eventually lead it from a manufacturing model to a mentefactura (mindfacture) model. For this, it is imperative that the Mexican public infrastructure be encouraged, promoted, and developed.

Given China's new role as an important exporter of capital, Mexico needs to develop a relationship with that country that attracts productive investment in Mexico. This should be done in such a way that the presence of China in Mexico benefits both countries, instead of just subtracting from Mexico as has happened under the current model. 


\section{References}

OECD (Organization for Economic Cooperation and Development). 2018. Trade in Value Added. Paris: OECD. www.oecd.org/industry/ ind/measuring-trade-in-value-added.htm. 


\title{
The New Digital Relationship between Mexico and China
}

\author{
José Ignacio Martínez Cortés \\ María del Carmen González Velázquez
}

The digital economy is a global phenomenon, in which the nations with greater industrialization have invested the most. Industrialized economies have a strong tendency to become knowledge-based economies.

Advances and technological innovations have given rise to the concept of Industry 4.0 or the fourth industrial revolution, characterized by uniting the production of high technological added value with manufacturing techniques based on knowledge. The new manufacturing techniques make it possible to manage information in order to reduce costs and labor as well as to develop products that provide greater competitiveness in the market. The 4.0 industry brings together organizations based on value chains through the Internet of Things, the Internet of Services, and cyber-physical systems.

Mexican industry can obtain great benefits, mainly in terms of cost and time savings, by automating; but the other side of the coin is the potential loss of jobs. The economically active population average in 2017 was 96.59 percent, of which 16.60 percent work in the manufacturing sector. In Mexico, 52 percent of manufacturing jobs are at risk of being replaced by machines, so training is needed on new technologies. Mexico has the seventh most youthful population in the world. A keyissue on international agendas is to deepen the liberalization of the high technologyindustry by means of economic competition and data protection. 
Therefore, the digital economy and telecommunications stand out among the issues addressed in recent NAFTA negotiations between Mexico, the United States, and Canada. China is another country that is increasingly immersed in the knowledge society through the development of high technology.

The digital economy will undoubtedly cause a relocation of production, not from one place to another but from mechanical to digital processes, and that is the key to drive the new commercial, technological, and manufacturing relationship between Mexico and China.

\section{Technological value added production in China and Mexico}

China has made significant efforts to transform its manufacturing structure to prioritize products with high added value. This transformation has been achieved based on policies and regulations that promote development guided by a new vision, in which innovation plays a leading role.

The institutional framework for this new vision is based on the Chinese economic reforms of 1978, and the Four Great Modernizations approach, which included the development of science and technology. China's sixth five-year plan (1980-1985) began to lay the foundations for the construction of a scientific/technological system, and subsequent plans provided guidelines for the development of an innovation system.

In addition to the five-year term plans, which specify the main national objectives, the government of China implemented regulations aimed at strengthening the innovation system, such as the 863 Program, the Spark Plan, the Torch Program, the 211 Program, and the State Plan for Medium and Long-Term Scientific and Technological Development (2006-2020).

Although China has established many institutions to promote this innovation-based vision of development, the central government considers the Made in China 2025 initiative as key to achieving the complete transformation of the production structure in the 21 st century. 
This initiative aims to "increase the quality of production through the application of new standards, automation and smart technologies, while emphasizing sustainable production" (Gómez Pérez-Cuadrado 2016:4).

To these ends, China has promoted the development of small, medium, and large companies as well as investment in higher education and research and development.

Mexico has adopted similar goals, especially in the following national initiatives:

1. The National Development Plan for 2013-2018 includes the objective of making science, technology, and innovation the pillars of sustainable economic development and social progress (Presidencia de la República, Objective 3.5).

2. The 2014-2018 Special Program for Science, Technology and Innovation has as its main purpose "to ensure that Mexican society appropriates scientific and technological knowledge and uses it to be more innovative and productive" (CONACYT, 2014) and to invest in strategic areas to increase scientific and technological production.

However, these efforts to promote the development of science and technology have been weak. Although they aim to promote higher education, the construction of innovation infrastructure, and the strengthening of human capital, no more specific regulations have been established to accomplish those objectives.

In terms of exports, one of the fundamental bases of its economy, Mexico is a leader in Latin America, along with Brazil, which has increased its exports of high-technology products, particularly telecommunications exports (Figure 1). However, without specific strategies and regulations to promote science, technology, and innovation, trade in high-tech products is limited. In fact, Mexico has a trade deficit in these products. 
Figure 1. Mexico's telecommunications exports (in us \$millions)

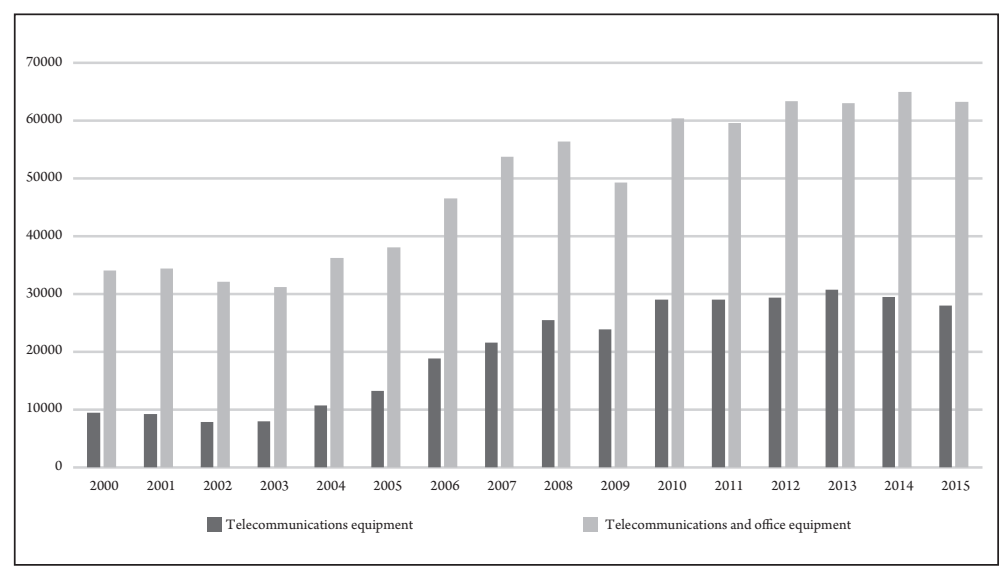

Data source: World Trade Organization (2016).

Mexico's high-tech exports are well below those of China (Figure 2). While Mexico's exports grew 57 percent from 2001 to 2016, China's increased 904 percent, as a result of its policies and regulations promoting innovation, science, and technology.

Figure 2. China's and Mexico's exports of high-technology products

(billions of dollars).

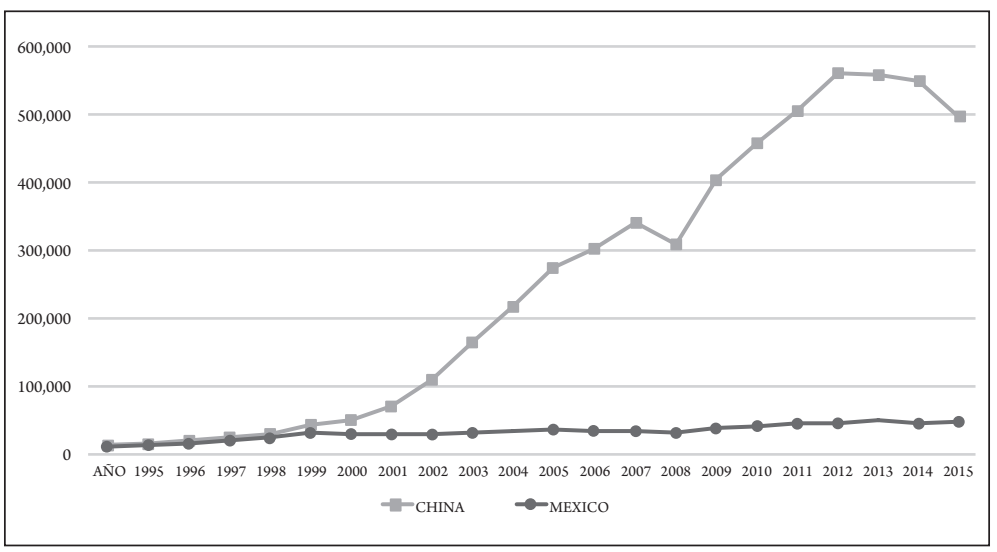

Data source: World Bank (2018). 
It is imperative for Mexico to take action to develop its scientific, technological, and innovative capabilities. Under current conditions, Mexico's opportunities to increase bilateral trade with China in value-added products are limited, since China has more advanced development of these products against which Mexican production could not compete.

\section{The digitalization of the Mexico-China relationship}

If Mexico intends to digitalize its relationship with China, moving the focus from low- to high-end products, it must take steps to, first, optimize its national industry, and then boost its commercial relations abroad. As Gary Gereffy (2015:27) stated:

In order to benefit from participation in global industries, developing countries must have the capacity to sustain and scale their competitiveness over time, institutionalize trade in their national economic development programs and develop internal capacity. ... The issue is not limited to the decision to participate or not in the world economy, but also to define how to do it profitably.

Mexico’s president-elect, Andrés Manuel López Obrador, whose sixyear term is set to begin in December 2018, must take good advantage of the closeness of the bilateral bond that Chinese President Xi Jinping has expressed in advance, so that at the end of Xis term, the relationship between the two countries is well consolidated. In this context, Mexico could follow a digitalization strategy with two channels -services and products- both offering high added value.

In view of the lack of productive complementarity between Mexico and China, and considering the development of high-value services in China, Mexico's best option in terms of services is to become a platform for the export of high-value-added services (mainly telecommunications) by Chinese companies to Latin America. That is, through the establishment of bilateral regulations that promote export outsourcing, 
Chinese high-value-added service companies could establish subsidiaries in Mexico that cooperate with Mexican companies that are capable of carrying out export activities for these services.

This would boost the bilateral relationship while helping to expand China's services market; it would also generate internationalization and learning opportunities for Mexican companies.

In terms of products, Mexico's main objective is to develop scientific/ technological production capacity. For this it will be necessary to negotiate technological license agreements, in which the licensor transfers to the licensee the right to use the technology of which he owns the intellectual property, as well as to manufacture, use and sell products related to that technology in an agreed manner during a specified period of time, and in a specified region. In other words, the licensor remains the owner of the rights related to that technology but has granted a right to use it. (w IPO 2010)Through such agreements, Mexico could intensify the development of a national technology industry and create an environment conducive to the assimilation and adaptation of knowledge, which could eventually lead to the creation of new national brands. Exporting these products would also require a thorough search for appropriate distribution channels.

A path forward toward successful digitalization of Mexico's foreign trade, in both products and services, is summarized in Figure 3. This will require changes in education, industrial, and investment policies, which should promote changes conducive to the construction of a new vision of development based on the promotion of scientific and technological capabilities and of innovation. 
Figure 3. Steps toward digitalization of the Mexico-China trade relationship

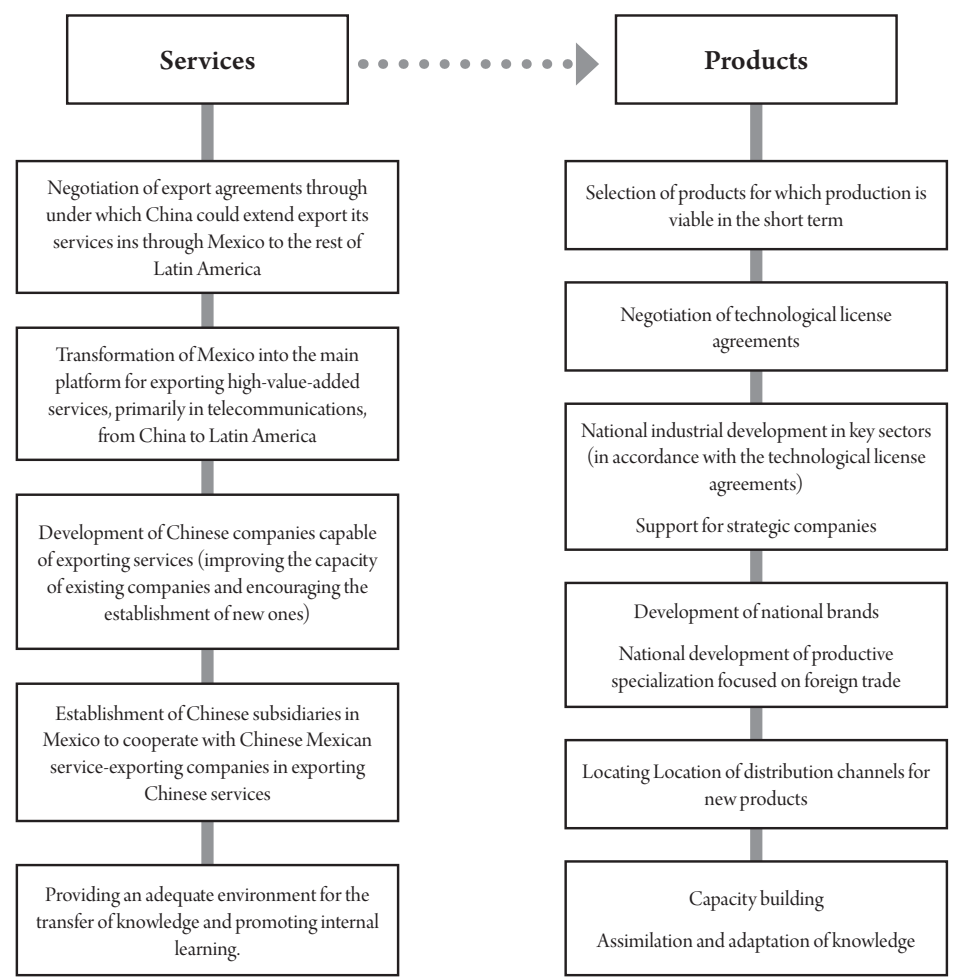




\section{References}

Consejo Nacional de Ciencia y Tecnología. 2014. Programa Especial de Ciencia, Tecnología e Innovación 2014-2018. www.siicyt.gob.mx/ index.php/normatividad/nacional/631-3-programa-especial-deciencia-tecnologia-e-innovacion-2014-2018/file (accessed March 1,2018).

Gereffy, Gary. 2015. "América Latina en las cadenas globales de valor y el papel de China." Boletín Informativo Techint 350 (SeptemberDecember): 27-40. http://iosapp.boletintechint.com/Utils/ DocumentPDF.ashx?Codigo=de1 ce0db-619e-4a11-b100afceaa4f331f\&IdType=2 (accessed February 28, 2018).

Gómez Pérez-Cuadrado, Esther.2016.Plan Made in China 2025. Beijing, China: Oficina Económica y Comercial de la Embajada de España en Beijing, ICEX. www.icex.es/icex/es/navegacion-principal/todosnuestros-servicios/informacion-de-mercados/paises/navegacionprincipal/el-mercado/estudios-informes/DOC2016671546. html?idPais=CN (accessed March 1, 2018).

Presidencia de la República. 2013. Plan Nacional de Desarrollo 20132018. México: Presidencia de la República.

World Bank. 2018. High-Technology Exports. https:// data.worldbank. org/indicator/TX.VAL.TECH.CD? end=2015\&locations=CN\&st art=1992\&view=chart (accessed February 28, 2018).

World Intellectual Property Organization. 2010. Intercambiar valor: Negociación de acuerdos de licencia de tecnología. wipo.int/edocs/ pubdocs/es/licensing/906/wipo_pub_906.pdf (accessed March 1,2018).

World Trade Organization. (2016). World Trade Statistical Review 2016. Geneve: wTo. 


\section{About the Authors}

Enrique Dussel Peters has been a professor in the Graduate School of Economics, Universidad Nacional Autónoma de México (UNAM), since 1993. His research interests include economic development, political economy, industrial organization, and trade theory; NAFTA and CAFTA; and the evolution of industrial, trade, and regional patterns in Latin America and Mexico. He has conducted research on specific segments of commodity chains, such as pineapples, lemons, electronics, yarn, textiles, clothing, auto parts and automobiles, and pharmaceuticals. His research has increasingly taken a comparative perspective (Latin America/Mexico-China). He served as coordinator of the Area of Political Economy at the Graduate School of Economics at U N AM from 2004 to 2008, and he is currently the coordinator of the Center for Chinese-Mexican Studies at UNAM, a position he has held since 2006. He also serves as the coordinator of the Academic Network of Latin America and the Caribbean on China (Red A LC-China). dusselpeters.com

María del Carmen González Velázquez is an internationalist and member of the Laboratory for Analysis of Commerce, Economy, and Business at the National Autonomous University of Mexico. 
Alejandro Gómez Tamez lives in the city of León, Guanajuato, Mexico. He obtained a BA in economics in 1995 at the Technologic Institute of Superior Studies of Monterrey, and in 1996 an M A in development policy and public administration at the University of Wisconsin-Madison. He has worked as the director of information analysis at the Information Center of the Guanajuato State Government (1997-2000); for the City of León as a city counselor (2000-2003), comptroller (2003-2006), and director of the Investments Unit and Project Bank (2009-2011); and for the Guanajuato State Footwear Chamber as the director of the Strategic Core (2011-2012), the general director (2012-2016), and currently as the executive president. He has also been active as the chief executive officer of the consulting firm GAEAP, as a professor of economics at the Technologic Institute of Superior Studies of Monterrey's León campus, EPCA University, and UnIVA University. He writes a weekly editorial column that is published in the newspaper El Heraldo de León and several Internet news sites.

Raul Hinojosa-Ojeda is founding director of the North American Integration and Development Center and associate professor at the University of California, Los Angeles. He founded the Center in 1995 to develop innovative research agendas and policy pilot projects concerning globalization and development. He received a BA in economics, $\mathrm{MA}$ in anthropology, and $\mathrm{PhD}$ in political science from the University of Chicago. He is the author of numerous articles and books on the political economy of regional integration in various parts of the world, including trade, investment, and migration relations between the United States, Mexico, Latin America, and the Pacific Rim. He has been a visiting scholar at the Inter-American Development Bank, the World Bank, and several academic institutions in Mexico and the United States. Together with Rep. Esteban Torres of California, he developed the proposal for the North American Development Bank, a \$3 billion institution that was created by the Us and Mexican governments in 1994. He has served as a board member of the Los Angeles Community Development Bank and the International Community Foundation and has been appointed 
to the Economic Strategies Panel of the State of California, the Los Angeles Office of International Trade, and the us Consumer Financial Protection Bureau.

Simón Levy-Dabbah is a young Global Leader by World Economic Forum since 2013 and a member of the World Entrepreneurship Forum, Urban World Forum 2015, and Global Agenda Councils. Founder of the Mexico-China lecture at UNAM. Undergraduate degree in law, with honors, specialist in Chinese law from Indiana University School of Law, Popular University of China; graduate in international management from ITAm and Graduate School of I te SM; PhD in law, public private partnerships, Un AM. He has taken PhD courses in private international law in The Hague, and in creation and globalization of enterprises in Madrid, and courses at Yale University's Lee Kwan Yew Public Policies School and Harvard's John F. Kennedy School. He served on the presidential campaign of Andres Manuel López Obrador, transition team for elect Head of CD mx, Dr. Mancera, assigned CE O of Procd mx, "Investment and Development Promotion Agency CD MX." He was the first Mexican lawyer to obtain a work permit in China, in 2005. He has served as the president of the Ideasia Fund, the first investment fund between Asia and Latin America; president of the LatinAsia Board, which introduces Mexican enterprises in Asia; and vice president of the China Holding Investment Group and of the Xinhua-Latinasia Council. He is a professor of constitutional law in the UNAM Graduate School and a member of the Leaders of the Future Club, International Affairs Mexican Council, and Child Fund Mexico.

José Ignacio Martínez Cortés received a PhD in international economics from the Universidad Complutense de Madrid. He is a professor and researcher at the National Autonomous University of Mexico in the Center of International Relations, where he coordinates the Area of International Economy. He is also the coordinator of the International Policy Axis of the Academic Network of Latin America and the Caribbean on China. 
Jorge Eduardo Mendoza Cota obtained a $\mathrm{PhD}$ in economics from the University of Utah. He is a full-time researcher in the Economic Studies Department at El Colegio de la Frontera Norte (e L COLEF). He has taught courses in international trade, North American economic integration, and labor economics at both EL COLEF and San Diego State University. He has been the director of economic studies and coordinator of the master's program in applied economics at EL COLEF, as well as of the master's program in regional economics at the Universidad Autónoma de Coahuila. He is currently a national researcher level II . He has published articles in Mexico, the United States, and Europe on the impacts of Us-Mexican economic integration on the Mexican economy and the impact of the Chinese economy on Mexican foreign trade. He has coordinated projects for CONACyT, OECD, SCERP, and the Economic Council of Tijuana. He has been a member of the Technical Committee for the Inter-institutional Program for Studies of the North American Region and the Evaluation Committee of Basic Science Projects at CONACyT.

Clemente Ruiz Durán is a full-time professor in the Graduate School of Economics at the Universidad Nacional Autónoma de México and a member of the Sistema Nacional de Investigadores (National Researchers Network). He has been a visiting professor at the Massachusetts Institute of Technology, University of California Los Angeles, Universidad Autónoma de Madrid, and Universidad General Sarmiento in Argentina. He has been engaged in research projects with the United Nations Conference on Trade and Development, Economic Commission for Latin America and the Caribbean, Interamerican Development Bank, and World Bank, and is currently conducting research with the International Labor Organization. He has written or coauthored more than 120 articles, written 17 books, and served as editor for 10 books. His recent publications include Crisis y rediseño del capitalismo en el Siglo xxi (M. A. Porrúa 2015) with a Chinese translation (Encyclopedia of China Publishing House 2015), "El Desarrollo empresarial en la Ciudad de México: el surgimiento de la clase creativa” in La Ciudad de 
México en el siglo xxi: principales transformaciones y tendencias (SECIT I 2016), and "México: Financial inclusion and literacy outlook" in International Handbook of Financial Outlook (Springer 2016), and, forthcoming with Patrizio Bianchi and Sandrine Labory, Transforming Industrial Policy for the Digital Age: Production, Territories and Structural Change (Edward Elgar Publishing 2018).

Cuiwen Wang is associate professor and chair of the Department of International Relations in the Zhou Enlai School of Government at Nankai University. She is also the vice general secretary of the China Association of Latin American Studies and an adjunct research fellow in the Center of Latin American Studies and National Human Rights Education and Train Base at Nankai University. She received her PhD in 2002 from Nankai University. She has research and teaching experience in the areas of international political economy and Sino-Latin American relations. She has undertaken research projects funded by the China Council of Social Sciences Foundation and Ministry of Foreign Affairs of the People's Republic of China and the Korean Foundation for Advanced Studies and Center for Asian Studies at Nankai University. Recent research and publications focus on China's approach to economic diplomacy.

Hongxia Wei is a senior fellow at the Institute of American Studies in the Chinese Academy of Social Sciences. Her research covers multilateral cooperation in the Asia-Pacific region, China-U s relations, US -Latin American relations, and American think tank studies. She is the author of Multilateral Cooperation in East Asia and China-us Relations (2014). Her publications also include "An Overview of American Think Tanks" in American Think Tanks and us Policy Toward China After the Cold War (2014), "The United States and APEC" and "Us Policy toward ASEAN" in U.s. Role in East Asia: Perceptions, Policies and Impacts (2008), and "Us Policy toward Latin America in the Post-Cold War Era” in us Foreign Relations in the Post-Cold War Era (2008). She has also published numerous articles in academic journals such as the American Studies Quarterly (now 
Chinese Journal of American Studies), Asia-Pacific Studies, Latin American Studies, and World Economics and Politics. She is the deputy director of the Chinese Journal of American Studies, Division of IL AS, CAS S. 



\section{Universidad Nacional Autónoma de México Facultad de Economía Centro de Estudios China-México}

The Renegotiation of NAFTA. And China?

Esta edición se terminó de imprimir en diciembre de 2018 en los talleres de Editores Buena Onda, S.A. de C.V.

Suiza 14, Col. Portales Oriente, Ciudad de México 03570

Su composición se realizó con las familias tipográficas:

Arno Pro 8:10; 9:15; 12:15

American typewriter $11: 15 ; 12: 15 ; 20: 30 ; 24: 26 ; 32: 34$

El tiraje consta de 500 ejemplares 



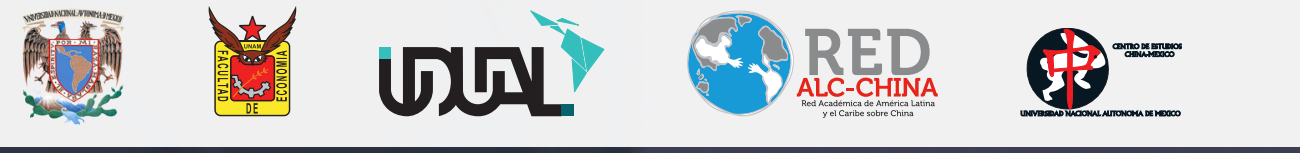

\section{THE RENEGOTIATION OF}

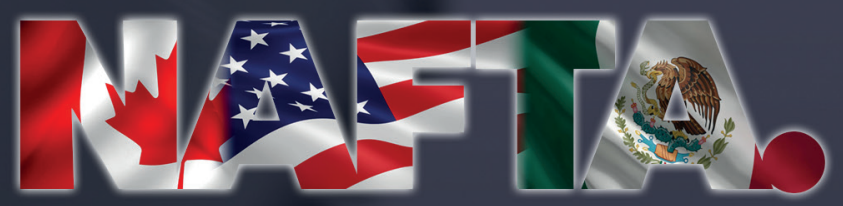

\section{AND}

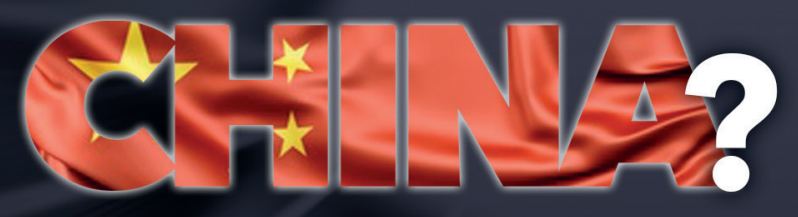

The goals of this book include analysis of the main results of the North American Free Trade Agreement (NAFTA) since January 1994 and the increasing relevance of China for the NAFTA region and each of its members. From this perspective, NAFTA, and what is now called the United States-Mexico-Canada Agreement (USMCA), should explicitly examine and evaluate the implications of China's rising presence in the region in several economic sectors and, based on this analysis, offer explicit policy responses to it. This, so far, has not happened either in NAFTA or in USMCA.

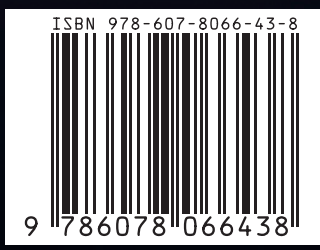

